\title{
STUDIES ON AUSTRALIAN MUSCIDAE (DIPTERA) II. A REVISION OF THE TRIBE DICHAETOMYIINI EMDEN
}

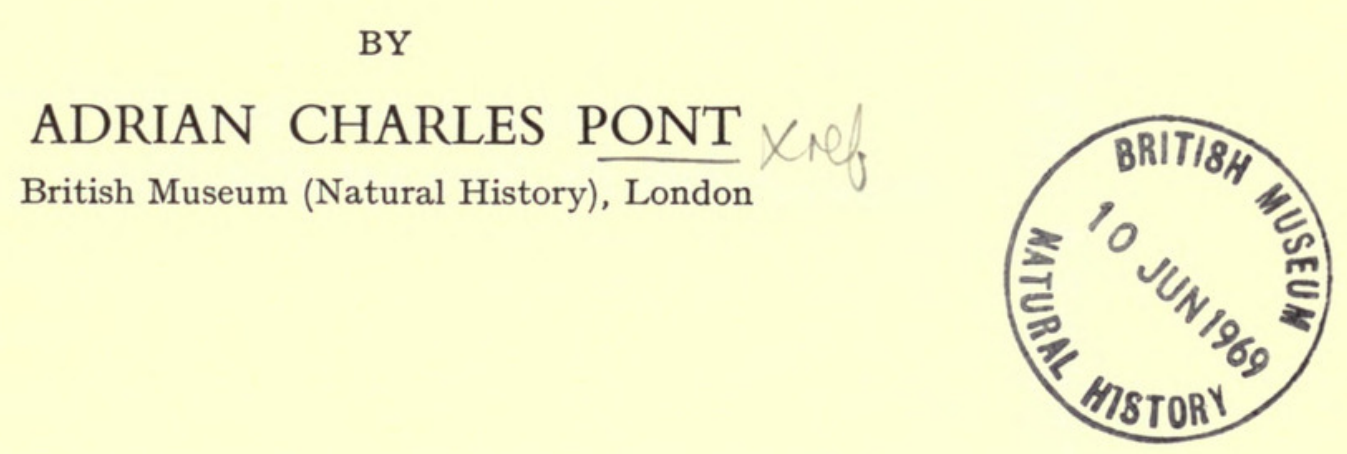

Pp. I9I-286; I05 Text-figures

\begin{abstract}
BULLETIN OF
THE BRITISH MUSEUM (NATURAL HISTORY) ENTOMOLOGY Vol. 23 No. 6
\end{abstract}

LONDON : 1969 
THE BULLETIN OF THE BRITISH MUSEUM (NATURAL HISTORY), instituted in 1949, is issued in five series corresponding to the Departments of the Museum, and an Historical series.

Parts will appear at irregular intervals as they become ready. Volumes will contain about three or four hundred pages, and will not necessarily be completed within one calendar year.

In I965 a separate supplementary series of longer papers was instituted, numbered serially for each Department.

This paper is Vol. 23, No. 6 of the Entomological series. The abbreviated titles of the periodicals cited follow those of the World List of Scientific Periodicals.

World List abbreviation:

Bull. Br. Mus. nat. Hist. (Ent.).

(C) Trustees of the British Museum (Natural History) 1969 


\title{
STUDIES ON AUSTRALIAN MUSCIDAE (DIPTERA) \\ II. A REVISION OF THE TRIBE \\ DICHAETOMYIINI EMDEN
}

\author{
By A. C. PONT
}

CONTENTS

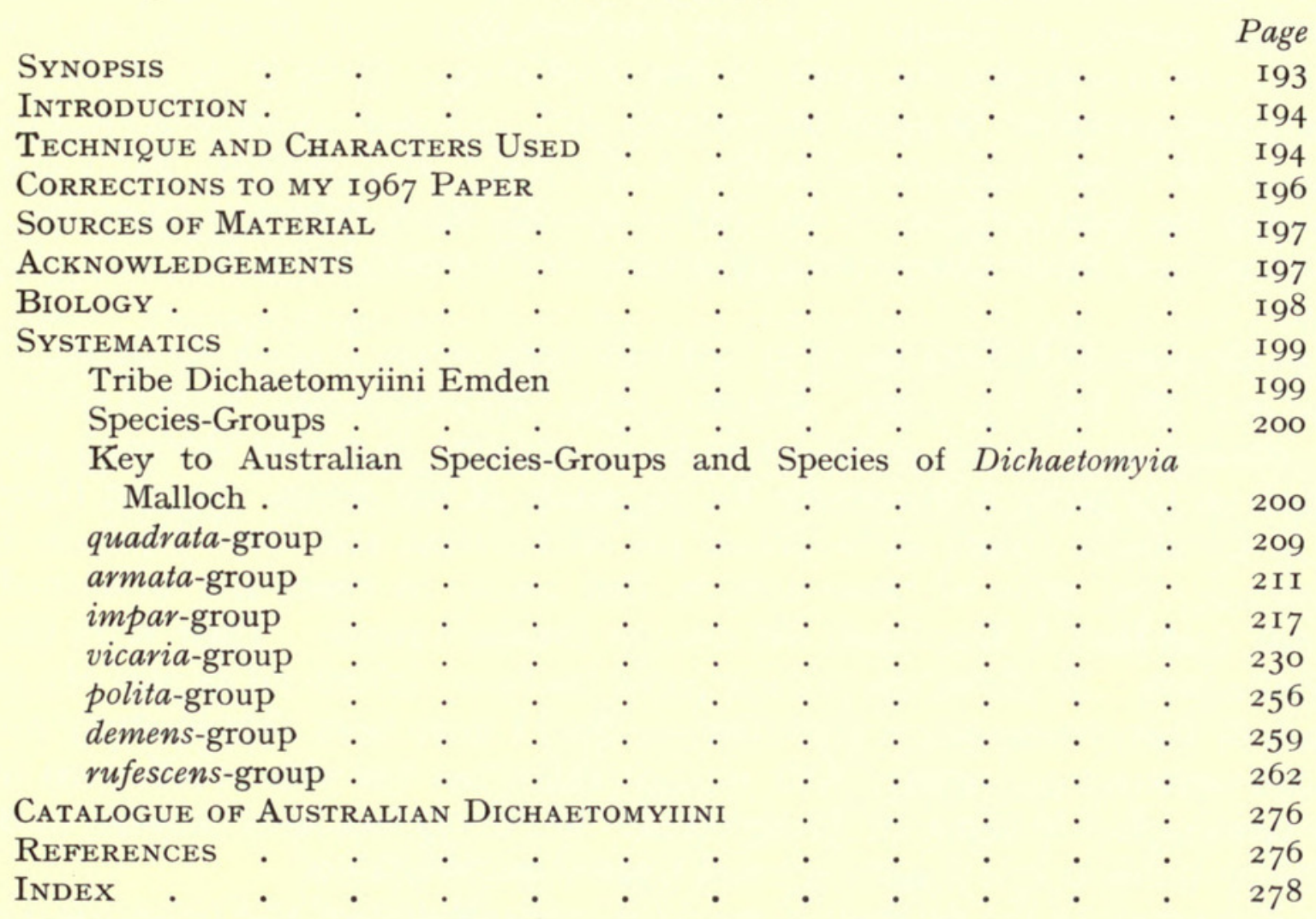

S Y NOPS IS

A systematic revision of the Australian species of Dichaetomyia Malloch is presented. A key to species is given, and all species except for megophthalma Malloch are redescribed and illustrated. Species-groups for the Australian fauna are proposed. Summaries of biology, ecology and distribution are given, and the puparium of parimpar sp. n. is described.

Twenty species are considered of which eleven are described as new: arrogans, aseta, australis, breviseta, collessi, fulvohirta, fusconota, parimpar, rufaeformis, soror and spinuligera. D. parviseta is described from the Solomon Islands. D. emdeni n. n. is proposed as a replacement name for polita Malloch, the type-species of the genus, a secondary homonym of polita (Stein). Agdestis Séguy is a new junior synonym of Dichaetomyia Malloch. D. helomyzina (Stein) and spinipes (Stein) are new junior synonyms of significans (Walker), rufa (Stein) and rufa var. personata Bezzi are new junior synonyms of vicaria (Walker), and luteohivta Malloch is a new junior synonym of reversa (Walker). Notes are given on the related species impar (Stein), apicalis (Stein) and rufescens (Stein).

All relevant types have been studied, except for those of megophthalma Malloch and flavohivta Malloch, and in the case of misidentified species all pertinent material has been seen. A neotype is designated for spinipes Stein, and lectotypes for impar Stein and rufa var. personata Bezzi.

ENTOM. $23,6$. 


\section{INTRODUCTION}

THIs second study in the series on Australian Muscidae presents a revision of the tribe Dichaetomyiini of the Phaoniinae which, in Australia, includes only the type-genus Dichaetomyia Malloch. The previous study (Pont, I967a) gave a revision of the quadrata- and armata-groups of Dichaetomyia, and the present paper offers supplementary data on these groups and a revision of the remaining Australian species.

The first and last revision of the Australian species was by Malloch (I925) who dealt with the ten species known to him, of which four were described as new. The present study, based on a much richer material than Malloch had, raises the number of Australian species to twenty, of which fourteen have been described as new. In addition, one non-Australian species is described here. Study of the available types has revealed a number of misidentifications, and some new synonymy has also been found, all of which is discussed below in the text. It is scarcely likely that this represents the total number of Australian species: more intensive collecting in the remoter parts of North Queensland will undoubtedly result in the discovery of further species.

Since the time of Malloch no work had been done on the Indo-Australasian Dichaetomyia until the last few years. Emden (I965) has revised the Oriental species, and as he studied most of the pertinent types in addition to giving thorough keys and descriptions his paper is invaluable for the study of the genus. Snyder (I965) and Hori \& Kurahashi ( $(967)$ have revised the Micronesian and some Japanese species respectively, but none of these authors had access to types nor to extra-limital material, and Hori \& Kurahashi did not use Emden's paper. Their work therefore contains errors. Work for the present paper has been carried out as part of a general revision of Indo-Australasian Dichaetomyia, and I have been able to study not only Emden's material and many other named collections but also a collection of over I,500 unidentified Melanesian Dichaetomyia, so that it has been possible to fit this Australian revision into a more general framework of studies.

For this paper all the Australian species have been studied and redescribed except for megophthalma Malloch. This species is still known only from the holotype, which I was unable to study, but it has been included in the key on the basis of information supplied by Mr. G. C. Steyskal. Species described in my previbus paper (Pont, r967a) are not redescribed here. Extra-limital material has been listed for the sake of completeness, and such biological information as is available has also been included.

\section{TECHNIQUE AND CHARACTERS USED}

In his revision of Australian Dichaetomyia (I925 : 324), J. R. Malloch wrote: “ As in the great majority of the Oriental species of the genus there are few striking specific characters one must resort to minute details for distinguishing the species. These however appear to be quite constant and with little practice one can readily distinguish the species." The present work attempts to clarify the Australian species but it has not been possible to make the study of this complex and subtle genus any less difficult than Malloch found it to be. Some species (e.g., the armata-group) are comparatively simple to distinguish in the male sex, but others and particularly females 
lack such striking structural features and other less obvious characters have to be used.

Characters of colour and dusting, and the presence or absence of fine hairs, are difficult to appreciate unless the specimen is in perfect condition. For this reason a large number of alternatives is given in the key whenever possible, and all critical characters are illustrated. In greasy specimens, pale setulae appear dark, and pale hairs, such as those on the metepisternum and squamopleuron, can only be distinguished with the utmost care. Previous authors (Malloch, I925; Snyder, I965; Hori $\&$ Kurahashi, I967) have stated that certain parts of the body (hypopleuron, squamopleuron, stem-vein) are bare or vary individually between bare and haired, but I have found that these areas are usually consistently haired or bare and that such statements often imply that the hairs in question have been overlooked.

Terminology follows that in use by other students of the Muscidae, and an explanation of abbreviations is given in my previous paper (Pont, I967a:620). Text-figs. I-3 illustrate unfamiliar characters that are used here. The squamopleuron (Text-fig. I) is that part of the metanotum below the lower squama, dorsad of the supra-spiracular convexity. The metepisternum (Text-fig. I) is situated at the lower posterior angle of the hypopleuron, above the hind coxa: the term was suggested by Dr. J. R. Vockeroth (letter of 5 th July, 1967) and is the same as Snyder's pre-episternite III. The vallar ridge (Text-fig. I) is a small narrow lip-like sclerite above the sub-alar ridge, and Mr. G. C. Steyskal (letter of I3th November, I967) pointed out to me that Hendel

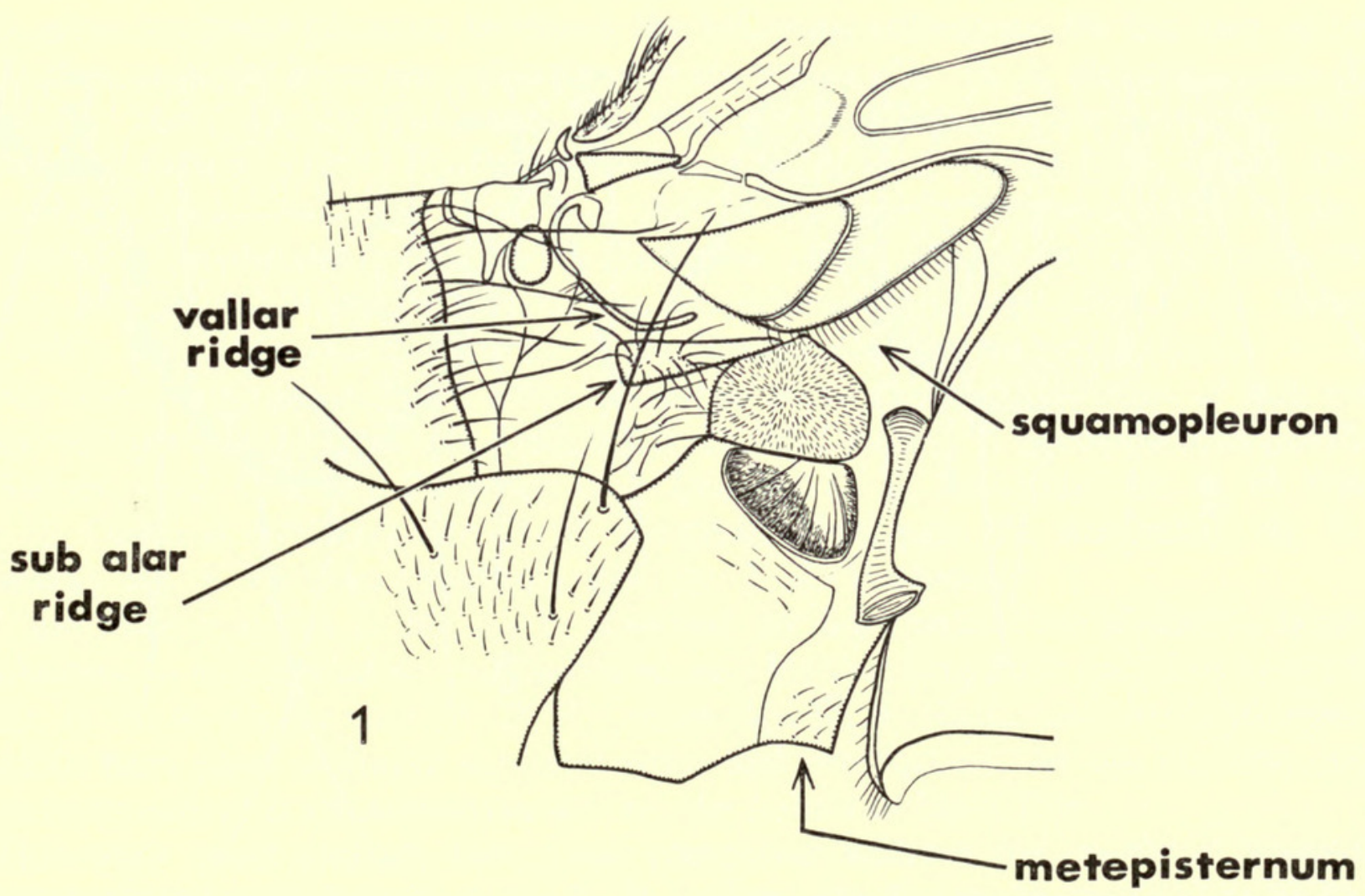

FIG. I. Posterior part of pleura of Dichaetomyia vicaria (Walker)

(Ingham, 17.vii.59, Harley, ô). 
(I9oo, Verh. zool.-bot. Ges. Wien $50: 325)$ had named this sclerite: it may or may not bear hairs on the anterior part. The ridge between inner post-alar seta and scutellum is indicated by the arrows in Text-figs. 2 and 3: it may or may not bear setulae.

Small specific differences have been found in the structure of the male 5 th sternite and hypopygium. These organs have been illustrated for each species, except for megophthalma.

Characters given in the key and the species-group descriptions are not repeated in the specific descriptions. Otherwise the species have been fully redescribed, and all available information on variation, relationships, habits and distribution has been given.

All illustrations have been prepared by the author, using a squared eye-piece. $5^{\text {th }}$ sternites and cercal plates have all been drawn to the same scale; lateral views of the hypopygia are drawn at $\mathrm{I} \cdot 5$ times this scale.

\section{CORRECTIONS TO MY I967 PAPER}

The following corrections to my previous paper (Pont, I967a) should be noted:

p. 632. Under armata, line 9. Delete " Material examined", and transfer lectotype data to between lines I and 2 (to before "Lectotype Designation").

p. 633. On the block of figures, fig. I4 is of norrisi and should be numbered " I5 ", fig. I5 is of significans and should be numbered "I4".

p. 635. Line 33. Delete " Material examined ", and transfer lectotype data to p. 632 to between lines I and 2 under significans (to before " designated by Pont ").
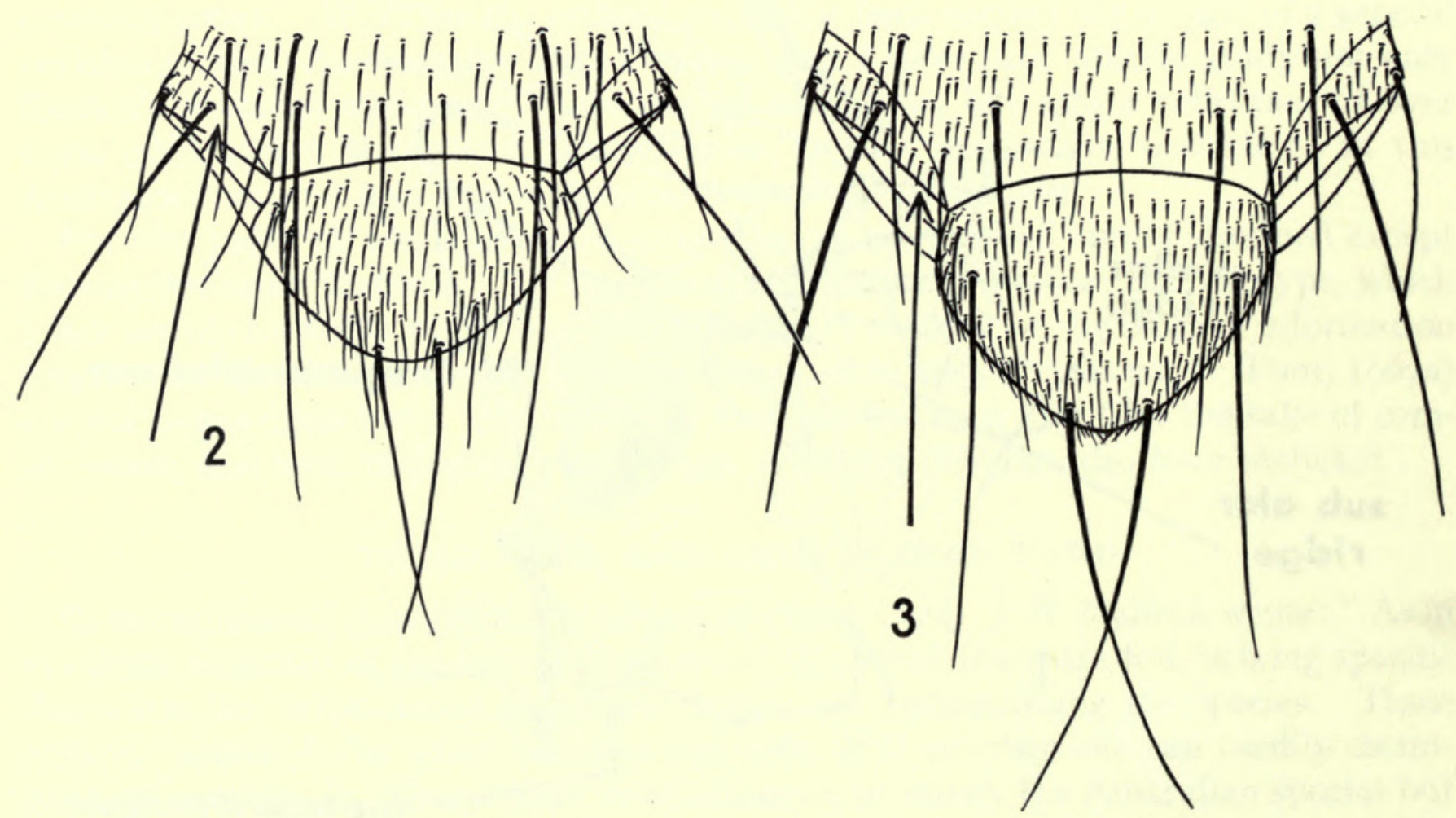

Figs. 2-3. Scutellum and post-alar ridge, dorsal view, of: 2, Dichaetomyia rufaeformis sp. n. (holotype); 3, D. significans (Walker) (TPNG, Nineia, Moroke, v. 6o, McMillan, ठ). 


\section{SOURCES OF MATERIAL}

Some 900 Australian specimens of Dichaetomyia have been studied for this paper. This and other material discussed is located in the following museums and institutions (abbreviations given are those used throughout the text in the lists of material examined):

Zoölogisch Museum der Universiteit van Amsterdam (Amsterdam); The Australian Museum, Sydney (Aust. Mus.); British Museum (Natural History), London (BMNH); Bernice P. Bishop Museum, Honolulu (Bishop); Universitetets Zoologiske Museum, Copenhagen (Copenhagen); Division of Entomology, C.S.I.R.O., Canberra (CSIRO); Museo Civico di Storia Naturale, Genoa (Genoa); Museo Civico di Storia Naturale, Milan (Milan); Muséum National d'Histoire Naturelle, Paris (Paris); Queensland Department of Primary Industries, Brisbane (Qld. Dept. Pr. Ind.); Queensland Museum, Fortitude Valley, Queensland (Qld. Mus.); South Australian Museum, Adelaide (S.A. Mus.); School of Public Health and Tropical Medicine, Sydney (SPHTM); United States National Museum, Washington (USNM); National Museum of Victoria, Melbourne (Vict. Mus.); Zoologisches Museum der Humboldt-Universität zu Berlin (ZMB).

\section{ACKNOWLEDGEMENTS}

It gives me great pleasure to thank the following colleagues for the loan of types and other material from the collections in their care: Dr. R. A. Brimblecombe (Qld. Dept. Pr. Ind.); Dr. D. H. Colless (CSIRO); Dr. E. Dahms (Qld. Mus.); Mr. W. N. Ellis (Amsterdam); Dr. J. L. Gressitt (Bishop); Dr. G. F. Gross (S.A. Mus.); Dr. D. Guiglia (Genoa); Professor D. J. Lee (SPHTM); Dr. C. Leonardi (Milan); Dr. L. Lyneborg (Copenhagen); Mr. D. K. McAlpine (Aust. Mus.); Dr. A. Neboiss (Vict. Mus.); Mr. K. R. Norris (CSIRO); Dr. H. Schumann (ZMB); Mr. G. C. Steyskal (USNM); Dr. L. Tsacas (Paris); Dr. J. R. Vockeroth (formerly at Bishop).

For discussion, advice, and help in various ways during the course of this work, I am very grateful to Dr. D. H. Colless, Dr. R. W. Crosskey (Commonwealth Institute of Entomology, London), Professor D. J. Lee, Mr. D. K. McAlpine, Mr. K. R. Norris, Mr. H. Oldroyd (BMNH), Mr. H. E. Paterson (Nedlands, W. Australia), Mr. G. C. Steyskal, Dr. J. Verbeke (Brussels), and Dr. J. R. Vockeroth.

I am most grateful to Mr. G. C. Steyskal for information on Malloch's types of Dichaetomyia megophthalma and flavohirta, and for checking their positions in my key.

Mr. D. K. McAlpine, and Dr. D. H. Colless, Mr. K. R. Norris and their colleagues at CSIRO, have most willingly supplied notes and recollections on the localities where they have collected Dichaetomyia and on the habits of these flies.

This work could scarcely have been completed without the continual invaluable encouragement and support of Dr. D. H. Colless who has made material available to me from his own and other museums, dealt with innumerable enquiries, and made special collections of Dichaetomyia during the course of his own field-work. 


\section{BIOLOGY}

What is known of the life-history and biology of Dichaetomyia has been summarized by Emden (I942 : 674-675, and I965: 334), Snyder (I965: 297) and Hori \& Kurahashi (I967 : 68). So far as I know, the only larval mouth-hooks and spiracles illustrated are those of nubiana (Bigot), figured by Emden (I965 : figs. Io h and II o). I have been unable to find the material upon which these illustrations are based. Not a single life-history is known in toto, and the only biological data available are random observations on a few scattered species.

Adult Dichaetomyia are found in the bush and in open country. They sometimes frequent faeces and even enter houses. Females are oviparous or ovoviviparous. Vivipary has been attributed to one species, but I very much doubt this as no ovipositor I have studied is adapted for vivipary. Larvae have been found in cattle dung, and they are saprophagous or coprophagous. Older larvae may be predaceous. According to Emden (I965:20) the dental sclerites are fused with each other so as to form a median ventral arch. This observation, if correct, confirms carnivory in at least the last larval instar.

So far as Australian species are concerned, the following facts are available, none of which have been reported previously.

Adult Dichaetomyia are most abundant in the north of Queensland, though some species have extended their range into Northern Territory and New South Wales. They are most commonly found in tropical rain forest, even in residual patches in dairy country or in narrow riverine tracts in dry country. They also occur in dry and wet sclerophyll forest, eucalyptus forest, agricultural country, savannah woodland, grassland savannah, and even in more open country and near the sea-shore. The emphasis seems to be on humid or shaded localities, though trappings frequently lure them into the open. Some species appear to be restricted to rain forest (polita-, demens- and rufescens-groups), whilst others are more tolerant of drier conditions (quadrata-, armata-, impar- and vicaria-groups). Records show a distribution from sea-level up to I,520 m. They appear throughout the summer months.

Adults are most frequently collected on leaves or by sweeping vegetation. They have been trapped in carrion-baited blowfly traps, buffalo-fly traps, Western Australian fly-traps, Malaise-traps and light traps. Some species have been collected on human faeces, and have been found in houses.

The puparium of one Australian species is known. The larva was found in a rotting $\log$ in wet sclerophyll forest just above rain forest. The dental sclerites are not fused ventrally, which indicates saprophagy. The posterior spiracles are closer together than in nubiana (cf. Emden, I965 : fig. II o). A remarkable structure is present in the lateral hooks that is apparently absent in nubiana (cf. Emden, I965 : fig. Ioh): the lateral hooks are spanned posteriorly by a narrow chitinous bridge which in its turn bears a weakly chitinized strip, possibly an apodeme. For fuller discussion, see below under parimpar (p. 222, and Text-figs. 34-37).

The genus is of no known agricultural or veterinary importance. Adults may be of some slight hygienic significance as they may act as mechanical vectors of faecaland carrion-borne pathogens. 


\section{Tribe DICHAETOMYIINI Emden, I95I}

Dichaetomyiini Emden, I951 : 377 and 679.

Diagnosis: Muscid flies with lower squama of the Phaonia-type, hind tibia without a calcar seta, prosternum and pteropleuron setulose, metathoracic spiracle with a row of black setulae along lower margin, arista long-plumose, vein I bare.

Emden (I942 : 675-676) included the genera Graueria Curran, Neaveia Malloch, Dichaetomyia Malloch and Pyrellina Malloch in his "Dichaetomyia-group", and in the same work (I942 : 736) synonymized Neaveia with Dichaetomyia. Subsequently (I95I : 376) he raised the group to tribal rank and removed Graueria to the Phaoniini. In his recent revision of Oriental Muscidae (I965:332-333) he has added a new genus Tamilomyia to the Dichaetomyiini. Hennig (I963:899-900, and I965:46 ff.) removed Pyrellina to the Muscini, and included in the tribe the Oriental Auria Malloch, the Indo-Australasian Rhynchomydaea Malloch, the Australian Hardyia Malloch and Gordonia Malloch, and the Ethiopian Alluaudinella Giglio-Tos, Aethiopomyia Malloch and Ochromusca Malloch.

Within the Australian fauna, the two genera Rhynchomydaea and Hardyia do not in my opinion belong to this tribe, and Gordonia Malloch (a junior synonym of Myiophaea Enderlein) belongs to the Muscini (Pont, I $967 b$ ), so that the only representative is the type-genus.

\section{DICHAETOMYIA Malloch, I92I}

Dichaetomyia Malloch, I92 I $a$ : I63. Type-species: Dichaetomyia polita Malloch, I921, nec Stein, I900 [ = emdeni n. n.], by original designation and monotypy.

Neaveia Malloch, I92 I $b: 427$. Type-species: Neaveia flavida Malloch, I92 I, by original designation and monotypy. (Synonymy by Emden, 1942 : 736.) Preoccupied by Neaveia Druce, I9ıо : Lepidoptera.

Lophomala Enderlein, I927 : 54. Type-species: Mydaea flavipalpis Stein, I9I 5, by designation of Malloch, I928a : 468 . (Synonymy by Séguy, $1937: 344$.

Panaga Curran, I928 : 353 (as subgenus of Dichaetomyia). Type-species: Dichaetomyia(Panaga) limbipennis Curran, I928 [= Spilogaster albivitta Stein, 1906], by monotypy. (Synonymy by Séguy, I937: 344.)

Macroxanthomyia Malloch, I930: 473 (as subgenus of Dichaetomyia). Type-species: Dichaetomyia distanti Malloch, I92 I, by original designation. (Synonymy by Séguy, I937 : 344 .)

Agdestis Séguy, I937:359. Type-species: Agdestis kouligianus Séguy, I937, by original designation and monotypy. syn. $\mathbf{n}$.

Dichaetomyia polita Malloch is a secondary junior homonym of polita Stein, I9oo, described as a species of Spilogaster Macquart but in fact belonging to Dichaetomyia (Pont, in press). D. polita Malloch is herewith renamed as emdeni n.n., in honour of the late Dr. F. I. van Emden for his outstanding work on this genus.

Diagnosis: As for the tribe. Distinguished from the other Old World genera of Muscidae by the setulose pteropleuron, metathoracic spiracle with black setulae along lower margin, and Phaonia-type lower squama.

Distribution: Throughout the Old World tropics, impinging upon the Palaearctic region (West Europe, Caucasus, Japan). In Australia known only from the north- 
eastern states, New South Wales, Queensland, Northern Territory, and islands in the Torres Strait.

Biology: See above (p. I98).

\section{SPECIES-GROUPS}

No attempt has previously been made to divide the species of Dichaetomyia into groups. Such a course is very desirable since there are clearly several hundred described and undescribed species in the genus, and the author has been working on such a project for some years. This study is still incomplete, but a number of groups is proposed and described in this paper. These are based on a study of most of the described species of the Indo-Australasian region in addition to a large number of undescribed ones, but it is probable that further studies will result in much modification. For the present, however, and in the context of Australian studies, these groups are considered satisfactory.

In the species-group descriptions, the first paragraph contains the diagnostic characters of the group. The second paragraph includes the supporting characters, which are found to vary from group to group but which are not necessarily diagnostic in whole or in part.

\section{Key to Australian Species-Groups and Species of DiCHaEtomyia Malloch}

I Scutellum setulose laterally, the discal setulae descending multiserially on to lateral surface of scutellum and at some points invading ventral surface.

Palpi yellow or mainly so. Vallar ridge bare (cf. Text-fig. I). Propleural, pteropleural and hypopleural setulae all black. Squamopleuron bare. Stem-vein bare above .

- Scutellum bare laterally, at the most with up to I 2 setulae present in I-2 irregular rows on upper part of lateral margin on or just below the level of the strong setae .

2 Scutellum of normal shape, viewed from above broader than long (the width measured between the sub-basal lateral setae) (Text-fig. 2). Tergite 5 entirely shining, without any dusting. Lower stpl seta much longer and stronger than the anterior one, placed closer to the posterior one than to the anterior one. Abdominal macrochaetae normal, comparatively weak and semi-decumbent. Prsc acr setae placed in front of the transverse level of the prsc $d c$ setae. The depth below lowest eye-margin equal to width of 3 rd antennal segment. Fore tibia without a submedian $p$ seta. 4 post $d c$ setae. Post-alar callus with setulae present on the ridge between inner seta and scutellum (as in Text-fig. 3 ). $\quad \delta$ : frons slender, at narrowest point eyes separated by at most twice diameter of anterior ocellus, interfrontalia seam-like, ors hair-like and rudimentary; hind femur with only normal rows of setae on ventral surfaces, an $a v$ row in apical half and a $p v$ row in basal two-thirds; lobes of 5 th sternite without shining prolongations (Text-fig. $6 \mathrm{I}$ ). 우 : vte hardly shorter than vti. Bulky species [quadrata-group] . . D. johannis Pont (p. 210)

- Scutellum elongate, viewed from above as long as broad (Text-fig. 3). Tergite 5 at least partly dusted, if without conspicuous dusting then shagreened and not glossy. Lower $s t p l$ seta subequal to or weaker than anterior one, equidistant or almost equidistant from the two upper ones. Abdominal macrochaetae on tergites 4 and 5 very strong and erect. Prsc acr setae placed behind the transverse level of the prsc $d c$ setae. The depth below lowest eye-margin equal to only half width of 3 rd antennal segment. Fore tibia often ( $\left.\delta^{\star}\right)$ or always (ㅇ) with a submedian $p$ seta. $\delta^{\star}$ : frons broad, at narrowest point eyes separated by at least width of 3 rd antennal segment, interfrontalia distinct and broad, ors strong; hind femur strikingly 
modified on ventral surfaces, with either tubercules or spines or tufts of setae or dense rows of long wavy setae; 5 th sternite with a shining prolongation to each lobe (Text-figs. 43-45). $\quad$ o: vte short, at most half length of vti (longiseta), otherwise scarcely distinguishable from the adjacent post-ocular setulae. Elongate species [armata-group] . . . . . . . . . . .

33 post dc setae. Post-alar callus without setulae present on the ridge between inner seta and scutellum (as in Text-fig. 2). $\quad \sigma^{*}$ : mid femur with up to $6 p v$ setae, otherwise without ventral setae, with a few $a d$ setae in basal third; mid tibia with only the normal 2 short $p$ setae; hind femur on ventral surfaces with neither tufts of setae nor tubercles nor spines, with series of long dense fine rather wavy setae, the $a v$ row beginning at basal $\frac{1}{6}$ to $\frac{2}{5}$, the $p v$ row at basal $\frac{1}{2}$ to $\frac{1}{3}$, with equally dense setae between the rows; hind femur without $a$ setae; hind tibia without $p$ setulae on median third. q: vte about half length of $v t i$, much stronger than the adjacent post-ocular setulae

D. longiseta Pont (p. 212)

- 4 post $d c$ setae. Post-alar callus with setulae present on the ridge between inner seta and scutellum (Text-fig. 3). $\sigma^{t}$ : mid femur either without any ventral setae or with numerous long dense setae on $p v$ surface, without ad setae; mid tibia with the $p$ setae extremely long, and with other modifications; hind femur on ventral surface with a strong spine in apical half, and in basal half with either a tubercle bearing numerous dense setae or a tuft of strong almost coagulated setae; hind femur with some strong $a$ setae; hind tibia with some short fine erect $p$ setulae on median third. 우: vte very short, much less than half length of $v t i$ and scarcely distinguishable from the adjacent post-ocular setulae

$\delta$ : fore tibia with a very long fine submedian $p$ seta; mid femur without ventral setae; mid tibia with only $2 p$ setae, with long dense setulae on $p v$ to $v$ surfaces; hind femur in basal half with a tubercle bearing numerous short stout setae that are flexed at tips. o: hind femur without any ventral setae in basal half; tergite 4 without marginal macrochaetae but with only short decumbent setae that are not or hardly different from those on tergites I +2 and 3 ; fore femur with I $p v$ seta at base and 4-5 in apical half, bare medially; parafrontalia more yellowish to brownish pruinose; dusted mesonotal vittae weaker, the $d c$ ones usually weak behind suture, often obsolescent between 3 rd $d c$ and scutellum

D. norrisi Pont (p. 213)

- $\delta$ : fore tibia without a submedian $p$ seta; mid femur with numerous long dense setae on $p v$ surface; mid tibia with more than $2 p$ setae, and with ancillary setae on adjacent surfaces, without a row of long dense setulae ventrally; hind femur without a tubercle in basal half, but instead with a tuft consisting of a few coagulated long setae. o: hind femur with I-4 weak ventral setae in basal half; tergite 4 with at least 2 strong erect marginal macrochaetae, similar to those on tergite 5 and very strikingly stronger and more erect than the weak decumbent marginals on tergites I +2 and 3 ; fore femur with the $p v$ row of setae complete, though weak in basal half; parafrontalia more silvery white to yellowish pruinose; dusted mesonotal vittae denser, the $d c$ ones of uniform density from neck to scutellum .

D. significans (Walker) (p. 214)

53 strong post $d c$ setae preceded by a weak fourth seta that is only about twice the length of a ground-setula, the first strong post $d c$ seta thus usually closer to the second strong seta than to suture or midway between these two points.

Prsc acr setae placed behind the transverse level of the prsc $d c$ seta. Fore tibia without a submedian $p$ seta. Squamopleuron bare. Metepisternum haired, otherwise hypopleuron bare. Stem-vein bare above. Pteropleuron virtually entirely dark setulose. Metatarsi and tibiae yellow. Disc of notopleuron with a few dark setulae around the bases of both setae. Sternite I black setulose at sides. Mesonotum and scutellum virtually undusted [impar-group] . $\cdot \dot{ }$.

- 3 or 4 strong post $d c$ setae, without a weaker seta in front, the first strong post $d c$ much
closer to suture than to the second strong one . . . . .

- 3 or 4 strong post $d c$ setae, without a weaker seta in front, the first strong post $d c$ much
closer to suture than to the second strong one . . . . . 
6 Tergites $I+2$ and 3 yellow or black fasciate or, rarely, entirely black in groundcolour, and the antero-lateral angles of tergite 4 also often black; tergites 4 and 5 always largely or wholly yellow, rarely discoloured by post-mortem decay, but in these cases the discoloured areas can with care be distinguished from the areas in which the ground-colour is truly black. Tergite 4 with the marginal row of setae weaker and less erect, the row usually interrupted medially. Tergite 5 with only 2-3 pairs of discal setae, confined to the lateral part of the tergite. $4^{\text {th }}$ tarsal segment on all legs yellow. $\delta$ : frons slender, at narrowest point eyes separated by diameter of anterior ocellus or less, the interfrontalia obsolete on median third of frons and not even a seam indicated, except in a few males where a weak seam is visible, upper inner eye-facets enlarged; ori separated from ors by a considerable bare gap (Text-fig. 30); viewed from above and behind, mesonotum with a pair of weak white-dusted prst vittae mesad of the $d c$ setae, these sometimes fused into a single broad vitta, and along prst $d c$ rows often with traces of more white dust, only three $\hat{\sigma}$ seen without any dust. $q$ : prosternum with the setulae always yellow; parafrontalia silvery white pruinose on lower third, brownish grey pruinose above

D. parimpar sp. n. (p. 219)

- Tergites I +2 and 3 entirely yellow in ground-colour; tergites 4 and 5 always entirely black in ground-colour and sometimes the posterior margin of tergite 3 also black. Tergite 4 with the marginal row of setae stronger, more erect and uniform, and not interrupted at middle. Tergite 5 with more numerous and stronger discal setae, 4-5 pairs forming almost a complete row. 4th tarsal segment on all legs brownish to black. $\delta$ : frons broader, at narrowest point eyes separated by twice diameter of anterior ocellus, by width of 3 rd antennal segment in frontal view, the interfrontalia distinct throughout between the parafrontalia and at narrowest point equal to diameter of anterior ocellus, upper inner eye-facets not at all enlarged; ori not usually separated from ors, the gap filled by short setulae (Text-figs. 32-33); viewed from above and behind, mesonotum entirely undusted, without traces of any white dust at neck or along prst $d c$ rows. o : prosternum with the setulae usually partly or entirely brown to black, sometimes entirely yellow; parafrontalia usually silvery white pruinose only at lunula, almost entirely brownish grey pruinose, but sometimes as in parimpar

D. breviseta sp. n. (p. 224)

$7 \quad 4$ strong post dc setae [vicaria-group]

- 3 strong post dc setae

8 Post-alar callus without setulae present on the ridge between inner seta and scutellum (Text-fig. 2). Setulae on pteropleuron entirely black. Setulae on prosternum black, at most a few of the posterior ones yellow. Propleural and prostigmatal ground-setulae black. Vallar ridge bare, rarely with I hair on anterior part. Setulae on notopleuron and hairs on squamopleuron entirely black. Beard virtually entirely black, with at most a few pale setae right behind.

Scutellum with o-4 setulae descending just below the level of the strong setae. Metatarsi yellow. $\delta$ : frons very slender, at narrowest point eyes separated by less than diameter of anterior ocellus; 3rd antennal segment largely darkened beyond insertion of arista; tibiae yellow; mid femur without pv setae. 우 (megophthalma unknown): mesonotum with a small median patch of white dust at neck . .

- Post-alar callus with setulae present on the ridge between inner seta and scutellum (as in Text-fig. 3). Setulae on pteropleuron either entirely yellow or brown above and yellow below. Setulae on prosternum yellow, rarely a few of the anterior or posterior ones brown. Propleural and prostigmatal ground-setulae yellow, or with a few brown ones intermingled with the yellow ones. Vallar ridge with several, usually pale, hairs on anterior part. Setulae on notopleuron and hairs on squamopleuron mainly or entirely yellow or brown. Beard with a few or many pale setae among the black ones. 
Setulae on sternite I yellow. Hypopleuron with the hairs below spiracle and on metepisternum pale to brown . . . . . . . . . .

9 Hypopleuron with the hairs below spiracle and on metepisternum yellow. Setulae on sternite I yellow. $\delta$ : hind femur with about 6 long median $p v$ setae, more or less equal to femoral depth, and 2-3 preapical av setae; upper inner eye-facets strongly and conspicuously enlarged, frons very slender, at narrowest point eyes separated by less than diameter of one of the adjacent eye-facets. o: unknown; probably with some short $p v$ setae on hind femur D. megophthalma Malloch (p. 238)

- Hypopleuron with the hairs below spiracle and on metepisternum black. Setulae on sternite I black. $\delta$ : hind femur without submedian $p v$ setae, if with $p v$ setae in apical half then they are much longer than femoral depth and at the same time there are 4-6 long av setae in apical half; upper inner eye-facets no more enlarged than is usual, not strongly and conspicuously so, though frons at narrowest point may be slightly broader than diameter of one of the adjacent eye-facets. $\%$ : hind femur without $p v$ setae

Io $\delta^{\text {: }}$ hind femur with $4-6$ av and $2-4$ p setae in apical half, all longer than femoral depth, otherwise bare ventrally (Text-figs. 4 and 6); prsc acr setae placed on or behind the transverse level of the prsc dc; auxiliary prostigmatal seta usually absent. o: indistinguishable from that of rufaeformis.

D. terraereginae Malloch (p. 23I)

- $\sigma^{t}$ : hind femur with a short submedian $p v$ seta, not as long as femoral depth, that is rarely indistinct, and with 2 long and o-I short preapical av setae, otherwise bare ventrally (Text-figs. 5 and 7 ) ; prsc acr setae placed in front of, rarely on, the transverse level of the prsc $d c$; auxiliary prostigmatal seta always present. $q$ : indistinguishable from that of terraereginae . D. rufaeformis sp. n. (p.
teropleuron with the setulae brown above and yellow below. Prsc acr setae placed behind, or rarely on, the transverse level of the prsc dc. Notopleuron with the setulae usually entirely black. Scutellum with 4 -Io setulae descending just below the level of the strong setae. Beard with a few yellow setae among the black ones. Tibiae often brown to black. Metatarsi brown to black. $\delta$ : frons very slender, at narrowest point eyes separated by diameter of anterior ocellus or less; 3 rd antennal segment yellow. o: mesonotum without a small median patch of white dust at neck

- Pteropleuron with the setulae entirely yellow. Prsc acr setae placed in front of, or rarely on, the transverse level of the prsc $d c$. Notopleuron with the setulae mainly or entirely pale. Scutellum with o-4 setulae descending just below the level of the strong setae. Beard with numerous golden setae among the black ones. Tibiae always yellow. Metatarsi yellow to brown. $\delta$ : frons slender, at narrowest point eyes separated by more than diameter of anterior ocellus, except in flavohirta; 3rd antennal segment usually infuscated beyond arista. of: mesonotum with a small median patch of white dust at neck

I2 Hind femur with a series of about $4 p v$ setae in basal half, that equal ( $\widehat{0})$ or almost equal (o) femoral depth (Text-figs. 8 and I2). Hind femur usually with 2(-3) $d$ preapical setae. Tergites $I+2$ to 4 fasciate: tergite $I+2$ yellow, with a dark hind-margin, tergites 3 and 4 dark, with a yellow fore-margin. $\delta$ : mid femur with a few $p v$ setae in basal third that almost equal femoral depth; upper inner eyefacets conspicuously enlarged, frons at narrowest point not as broad as diameter of one of the adjacent eye-facets; scutellum undusted, even in posterior view; abdomen in posterior view virtually undusted . . D. australis sp. n. (p. 239)

- Hind femur without $p v$ setae, though often with a few stronger setulae around middle ( $\left.\widehat{o}^{*}\right)$ or in basal half (ㅇ), but these are never half as long as femoral depth (Text-figs. 9 and I3). Hind femur with I $d$ preapical seta. Abdomen variable, never fasciate as above: varying from wholly yellow, to yellow with apical tergites darkened, sometimes even more extensively darkened, generally due to post-mortem decay. $\checkmark$ : mid femur without $p v$ setae, the longest setulae at most half femoral depth; 
upper inner eye-facets not conspicuously enlarged, frons at narrowest point as broad as or broader than one of the adjacent eye-facets; scutellum in posterior view whitish dusted, more densely so in basal lateral corners; abdomen in posterior view rather thinly but uniformly grey to whitish grey dusted . D. vicaria (Walker) (p. 242)

I3 3 o
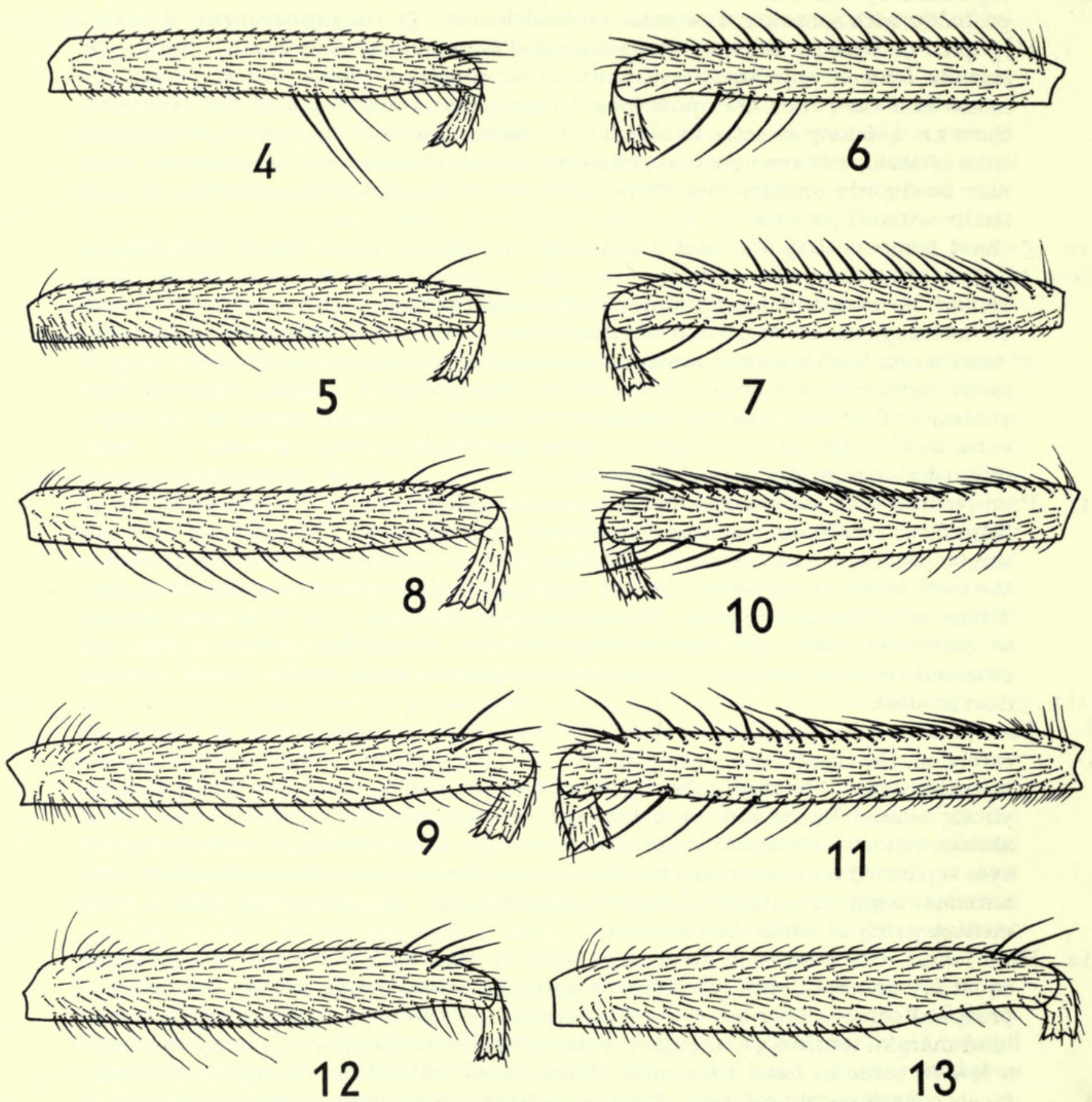

FIgs. 4-I3. Hind femora of the Dichaetomyia vicaria group: 4 , D. terraereginae Malloch, ô, posterior view (Q, Bancroft, paratype); 5, D. rufaeformis sp. n., ô, posterior view (Q,

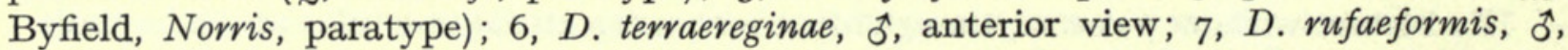
anterior view; $8, D$. australis sp. n., ô, posterior view (Q, Bamaga, 28.iii.64, paratype); 9, D. vicaria (Walker), ô, posterior view (Q, I4 mls S.W. of Sarina, 8.v.55); 10, D. australis, $\hat{\delta}$, anterior view; II, D. vicaria, $\hat{\delta}$, anterior view; $12, D$. australis, + , posterior view (Q, Kuranda, Turner, paratype); I3, D. vicaria, ㅇ, posterior view (Q, I4 mls S.W. of Sarina, 8.v.55). 
I 4 Upper inner eye-facets strikingly and conspicuously enlarged, frons at narrowest point not as broad as one of the adjacent eye-facets and much narrower than diameter of anterior ocellus, interfrontalia completely obsolete on over median half of frons. Head in lateral view with the parafrontalia and parafacialia largely invisible. Parafacialia slender, opposite insertion of arista equal to slightly less than diameter of anterior ocellus.

Hind femur on $p v$ surface with a series of slightly longer setulae, not half femoral depth, but without setae (Text-fig. I4); with a row of $a v$ setae, strongest in apical half, many longer than femoral depth, short and often vestigial towards base (Text-fig. I7) • . $\quad . \quad \cdot \quad \cdot \quad . \quad . \quad D . f l a v o h i r t a$ Malloch (p.

- Upper inner eye-facets not strikingly and conspicuously enlarged, at narrowest point of frons eyes separated by twice or a little over twice diameter of anterior ocellus, interfrontalia visible as a deep seam throughout and nowhere obsolete. Head in lateral view with the parafrontalia and parafacialia visible but slender. Parafacialia opposite insertion of arista equal to a little over diameter of anterior ocellus

I5 Hind femur on $p v$ surface with a series of slightly longer setulae, not half femoral depth, but without setae (Text-fig. I5); with a row of 7-9 av setae in apical half, many longer than femoral depth, bare in basal half (Text-fig. I8). Mid femur with at most a few $p v$ setae in basal half, not nearly as long as femoral depth, usually without any setae distinct from the ground-setulae. Upper post-ocular setulae, below the upper row, black

D. reversa (Walker) (p. 25I)
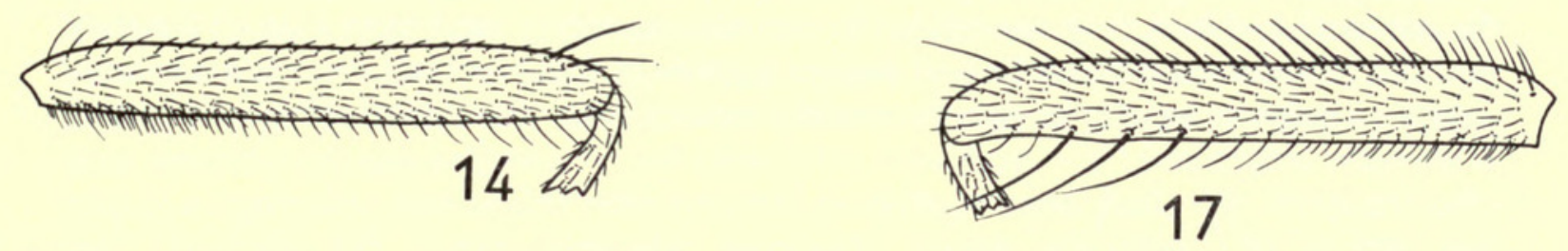

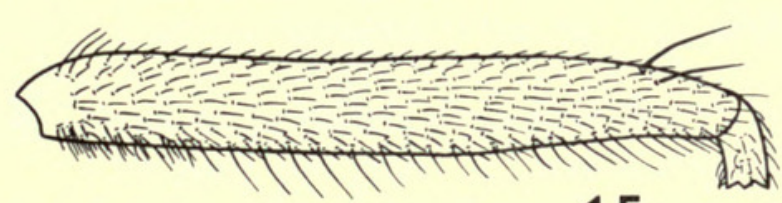

15
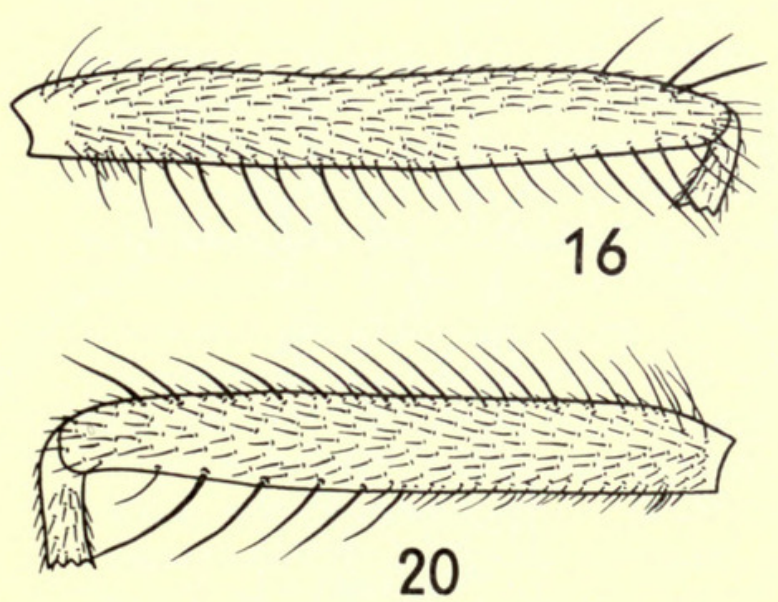
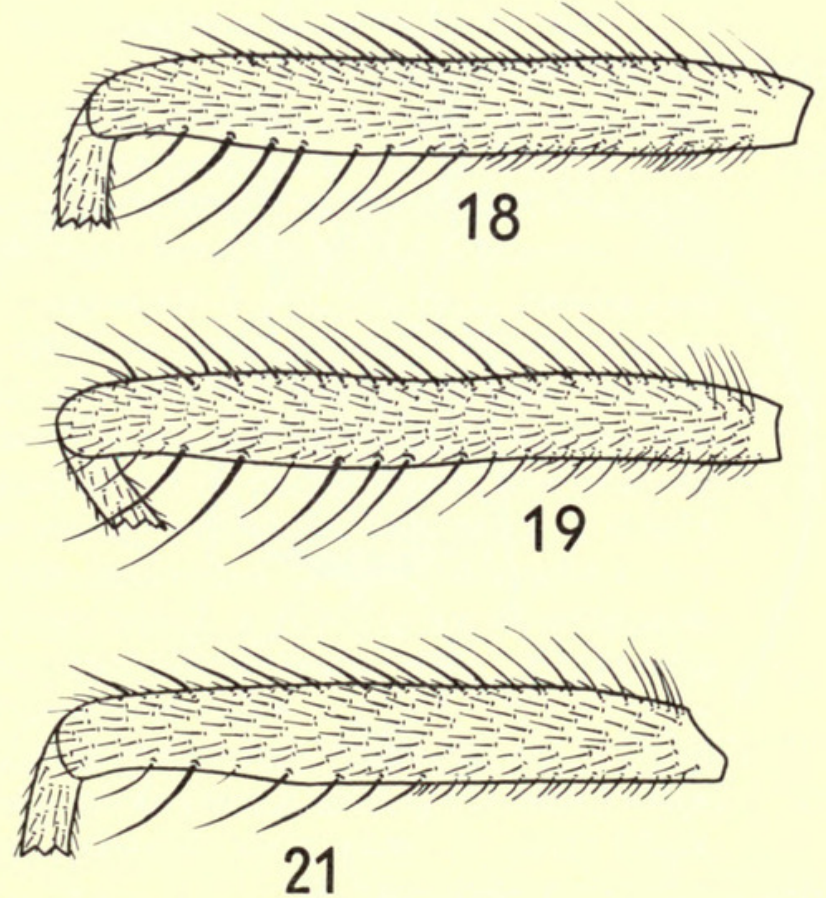

Figs. I4-2I. Hind femora of the Dichaetomyia vicaria group. I4-I6, $\widehat{0}$, posterior view, of: I4, D. flavohirta Malloch (Q, Cairns, ex corn, Illingworth); I5, D. reversa (Walker) (Thursday Is., Copeman); I6, D. fulvohivta sp. n. (holotype). I7-I9, ô, anterior view, of: I7, D. flavohirta; I8, D. reversa; I9, D. fulvohirta. 20-21, ㅇ, anterior view, of: 20, D. flavohirta (Q, Cairns, ex corn, Illingworth); 2I, D. veversa (Q, Yeppoon, Io.v.55, Norris). 
- Hind femur on $p v$ surface with a weak row of setae that are longest around middle and just before apex where they are almost equal to femoral depth (Text-fig. I6); with a row of $a v$ setae, those in basal half short, those in apical half longer than femoral depth (Text-fig. I9). Mid femur with some long $p v$ setae in basal half, as long as femoral depth, the row becoming shorter in apical half and merging with the ground-setulae. Upper post-ocular setulae, below the upper row, pale

D. fulvohirta sp. n. (p. 255)

I6 Hind femur with the $a v$ setae stronger, 3-4 strong and 2-5 weak setae in apical half (Text-fig. 20). Lower ors usually more than half length of upper ors. Frontal triangle usually slightly longer, extending well over half the distance from ocellar tubercle to lunula

D. flavohirta Malloch (p. 248)

- Hind femur with the av setae weaker, I-2 strong and 4-5 weak setae in apical half (Text-fig. 2I). Lower ors usually half, or less than half, length of upper ors. Frontal triangle usually slightly shorter, extending only half to two-thirds the distance from ocellar tubercle to lunula . . . . . D. reversa (Walker) (p. 25I)

I7 Squamopleuron bare.

Femora and pleura entirely yellow. $\delta$ : fore femur without a series of short $a v$ spinules in apical half. o : fore tarsi without the apical segments enlarged. .

- Squamopleuron haired.

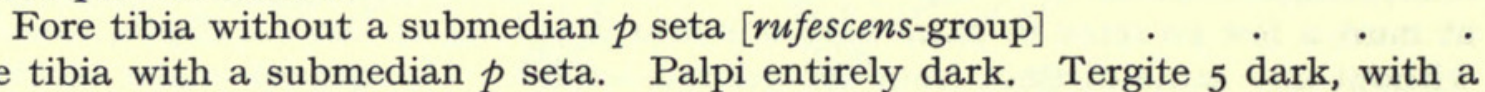

Fore tibia with a submedian $p$ seta. Palpi entirely dark. Tergite 5 dark, with a
yellow hind-margin. Hind cross-vein almost straight. Scutellum with 6-1o setulae descending in I-2 irregular rows just below the level of the strong setae. Beard entirely black. $\delta$ : scutellum in extreme posterior view with a small patch of whitish dust in each basal lateral angle; 2 pairs of fine reclinate ors; 3rd antennal segment beyond arista orange to weakly infuscated. o : viewed from above and

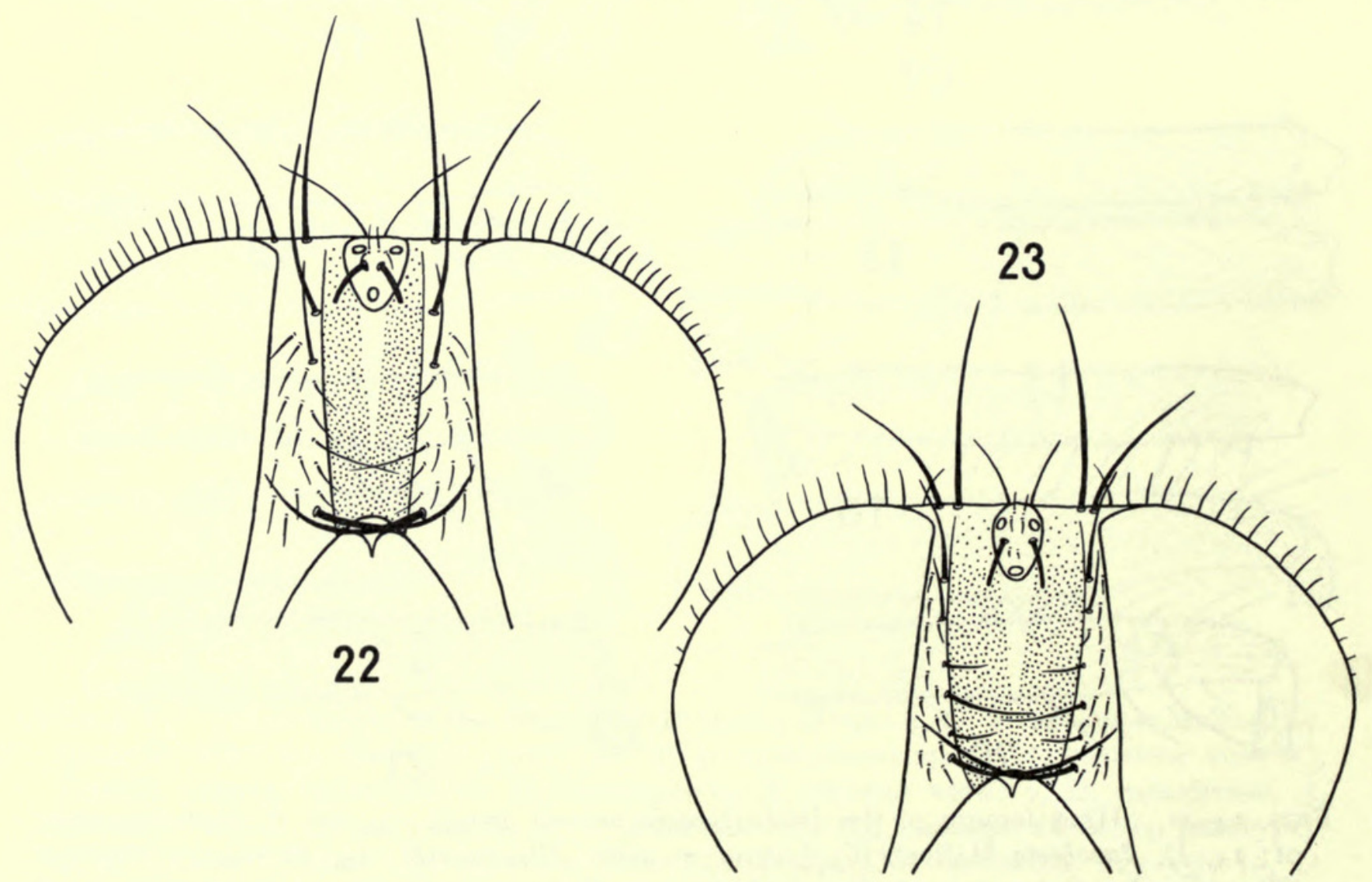

Figs 22-23. Frons of + Dichaetomyia, dorsal view: 22, D. collessi sp. n. (Q, Bamboo Ck, 25.iv.67, paratype); 23, D. aseta sp. n. (Q, Upp. Mulgrave R., 9.v.67, paratype). 
behind, mesonotum with 3 narrow weak white dusted vittae, a pair along the $d c$ rows, and a median one that is sometimes vestigial; tergite 4 with a row of marginal macrochaetae; at middle of frons a parafrontale half width of the interfrontalia; I strong pair of ori at lunula, with a weak pair above them (Text-fig. 22) [polita-group]

D. collessi sp. n. (p. 257)

- Fore tibia without a submedian $p$ seta. Palpi yellow, sometimes darkened towards base. Tergite 5 yellow, with a pair of black lateral spots that are small in o. Hind cross-vein sinuate. Scutellum with only 2-5 setulae at or just below the level of the strong setae. Beard with a few golden setae among the black ones. $\widehat{\delta}$ : scutellum even in extreme posterior view undusted; I pair of fine reclinate ors; 3rd antennal segment entirely pale yellow. क : viewed from above and behind, mesonotum undusted, with only faint traces of a median pale dusted patch at neck that sometimes continues just behind suture; tergite 4 without macrochaetae, or with just a few lateral marginals; at middle of frons a parafrontale a quarter width of the interfrontalia; I strong pair of ori at lunula, with 2-3 weak pairs above them (Text-fig. 23) [demens-group]

. D. aseta sp. n. (p. 26o)

Femora infuscated on all but apical quarter. Pleura largely infuscated. Propleural and prostigmatal ground-setulae entirely dark. o : viewed from above and behind, mesonotum rather densely dusted, with a paramedian pair of vittae, a pair of prst patches between $p h$ and $d c$, and a pair of post vittae between $d c$ and $i a$ undusted.

Palpi brown, extreme tips sometimes appearing yellowish. Beard entirely dark. Mesopleural ground-setulae entirely dark. Hypopleuron bare below spiracle, the hairs on metapisternum dark and pale. Squamopleuron with the hairs black. Sternite I dark setulose. All tarsi dark. Hind femur with a row of strong pv setae from base almost to apex ( $\left.\iota^{\star}\right)$ (Text-fig. $3^{8}$ ) or a few pv setae in basal half (ㅇ); $a v$ setae as in Text-fig. 40. Mid femur with I $a$ and I ad preapical setae. Abdomen entirely orange-yellow. Hind tibia with I $a v$ seta. $\hat{\sigma}$ : fore femur without a row of $a v$ spinules; mid femur with a row of $p v$ setae in basal half. o : fore tarsi normal (Text-fig. 28); supra-spiracular convexity pilose; ori above the lowest pair directed inwards (Text-fig. 26); abdominal macrochaetae as in Text-fig. 24

D. fusconota sp. n. (p. 266)

- Femora and pleura entirely yellow. Propleural and prostigmatal ground-setulae pale, or dark and pale. 9 : mesonotum with dusting very reduced, not as above .

$\sigma^{t}$ : fore and mid femora each with a series of short $a v$ spinules in apical half (Text-fig. $42)$; mid femur with a row of $p v$ setae in basal half; hind femur with complete rows of $a v$ and $p v$ setae (Text-figs. 39 and $4 \mathrm{I}$ ). $\quad$ \%: segments 3-5 of fore tarsi dilated and flattened (Text-fig. 29); hind femur with some $p v$ setae around middle; supraspiracular convexity with conspicuous long pale setulae among the pile; viewed from above and behind, mesonotum with only 3 weak dusted vittae, a median one and a paramedian pair, from neck to 2 nd post $d c$ setae, and a lateral fascia along suture to $d c$ rows; abdominal macrochaetae strong and stout, tergites $\mathrm{I}+2$ to 5 each with only I lateral discal and 2 lateral marginal setae, except for tergite $I+2$ which lacks the discal (Text-fig. 25). Scutellum with 7-9 (ô) or 9-13 (9) setulae in I-2 irregular rows descending just below the level of the strong setae. Stem-vein bare above. Mid femur with I $a$ and I $a d$ preapical setae.

ㅇ ori above the lowest pair directed inwards and forwards (Text-fig. 27). Palpi yellow, except at base in $\hat{\sigma}$. Beard with some golden setae among the black ones. Prosternum entirely pale setulose. Squamopleuron with pale to dark hairs. Hind tibia with $\mathrm{I}-2$ av setae.

D. spinuligera sp. n. (p. 263)

- $\quad \widehat{\sigma}$ : fore and mid femora without spinules; mid femur with no, or a few short, $p v$ setae; hind femur with only 2-4 av setae, before apex, and without $p v$ setae. $\quad$ : fore tarsi normal (as in fusconota, Text-fig. 28); hind femur without $p v$ setae; supra-spiracular convexity pilose only; viewed from above and behind, mesonotum completely undusted or with a lateral dusted fascia along suture to $d c$ rows; abdominal macro- 


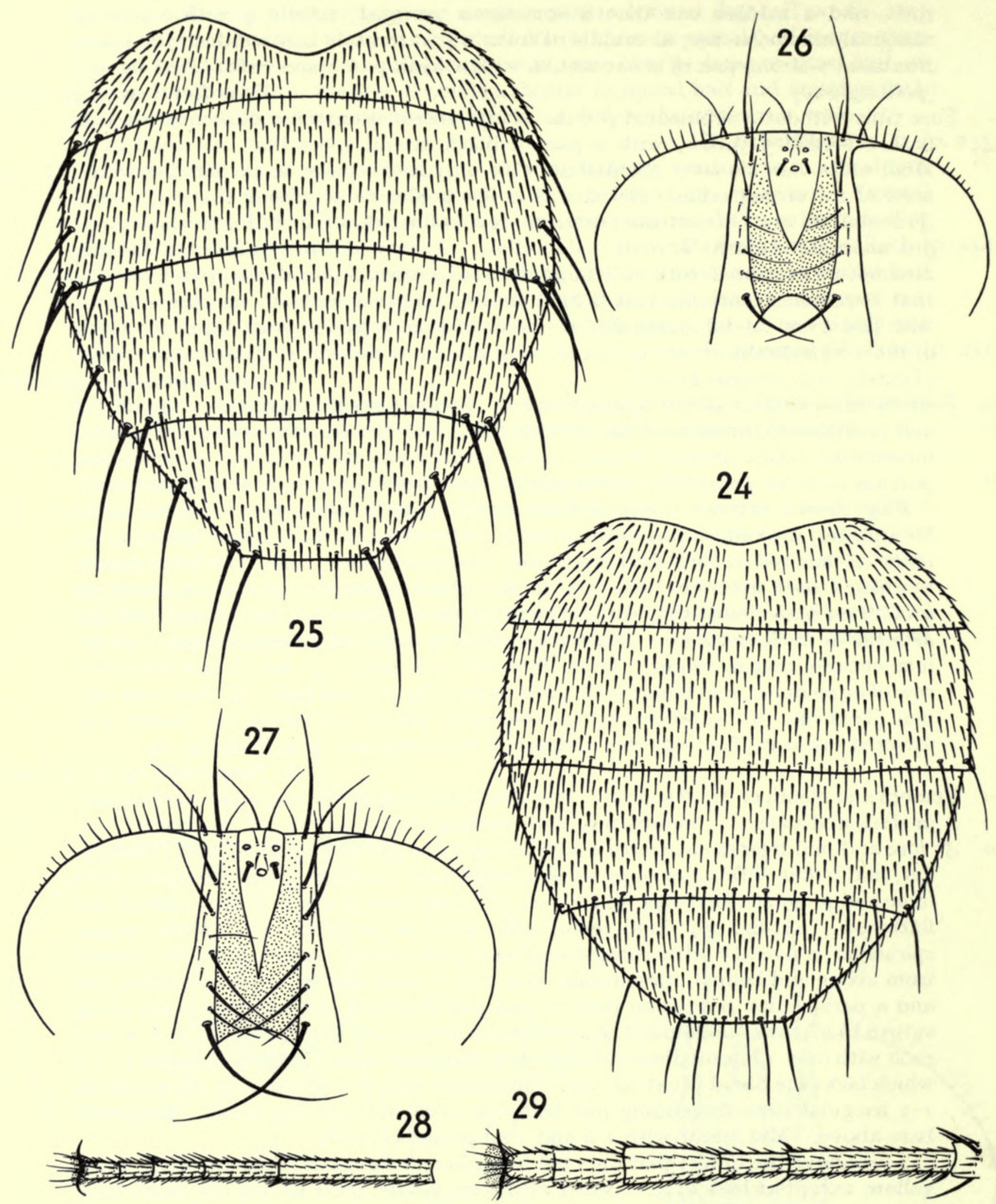

FIGs. 24-29. Dichaetomyia rufescens group. 24-25, abdomen, ㅇ, dorsal view, of: 24, D. fusconota sp. n. (Q, Kuranda, ix. Io, paratype); 25, D. spinuligera sp. n. (Q, Bamboo Ck, 25.iv.67, paratype). 26-27, frons, ㅇ, dorsal view, of: $26, D$. fusconota; $27, D$. spinuligera. 28-29, fore tarsus, o, dorsal view, of: 28, D. fusconota (right tarsus); 29, D. spinuligeva (left tarsus). 
chaetae normal and weak, tergites 4 and 5 only with some lateral discal and marginal setae (as in fusconota, Text-fig. 24). Scutellum with only $\mathrm{I}-9$ setulae descending just below the level of the strong setae. Stem-vein with a few microscopic hairs above, usually at base. Mid femur with only the $a$ preapical seta, rarely individually also with an ad in arrogans.

Palpi with at least apical half yellow, often entirely yellow. Hind tibia with 2(-3) av setae ( $\mathrm{I}$ only in $\mathrm{I} \delta^{\hat{}}$ and $\mathrm{I}$ \%). Beard with several golden setae among the black ones. Hypopleuron usually bare below the spiracle, sometimes with a few pale hairs. $\delta$ : tergite 5 with only lateral discal setae. 9 : ori above the lowest pair directed inwards and forwards, and interfrontalia with the margins almost straight (as in spinuligera, Text-fig. 27)

D. arrogans sp. n. (p. 270)

- Palpi dark, rarely with extreme tips pale. Hind tibia with I av seta (2 in I ô $^{\star}$. Beard entirely black. Hypopleuron always with some fine hairs below spiracle.

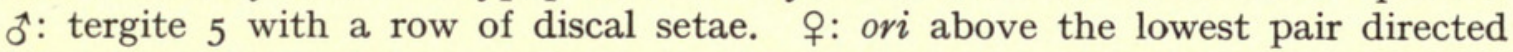
inwards, and margins of interfrontalia convex (as in fusconota, Text-fig. 26)

D. soror sp. n. (p. 273)

\section{THE QUADRATA-GROUP}

This small group includes 6 described species (with 2 subspecies) in which the scutellum is broader than long when viewed from above (as in Text-fig. 2) and possesses dark discal setulae that extend on to the lateral surfaces at all points and even invade the ventral surface, fore tibia without a submedian $p$ seta, and squamopleuron bare.

The quadrata-group possess the following additional characters:

Mentum of proboscis dusted. Prst acr setulae 9- to Io-serial. 2 strong prst dc setae; 3 or 4 post $d c$ setae. Pra seta short, about half length of 2 nd $n p l$ seta. Vallar ridge bare. Lower $s t p l$ seta longer and stronger than anterior one, closer to posterior one than to anterior one. Hypopleuron with numerous dark setulae below spiracle and on metepisternum. Stem-vein bare above. Lower squama bare. Abdominal macrochaetae strong and erect, but not strikingly strong. Male frons slender, at narrowest point eyes separated by less than width of 3rd antennal segment, ors hair-like, legs without modifications, 5th sternite normal and lobes without shining posterior prolongations. Broad squat species.

This group is most closely related to the armata-group, from which it can be distinguished by the shape of the scutellum (cf. Text-figs. 2 and 3), by the arrangement of the stpl setae, and by the secondary male characters. It is clearly a successful group and is found in all parts of the world to which Dichaetomyia has spread except for Micronesia and the remoter Pacific islands, Japan, and the Malagasy subregion.

D. nubiana nubiana (Bigot) is distributed throughout Africa and the Orient, and the subspecies aureomarginata Emden is known from Malaya and Indonesia. D. quadrata quadrata (Wiedemann) is Oriental and Papuan in distribution, and the subspecies monticola Emden is known from Malaya. D. peroe (Walker) is recorded from India and phaeocnemis Emden from Malaya. D. caucasica Pont is a Palaearctic species, from Azerbaydzhan, and johannis Pont is an Australian species.

The distribution in the Indo-Malayan region of nubiana and quadrata with their subspecies is still not clear, nor have the Melanesian species been worked out. From material I have seen, there are a number of Melanesian subspecies related to quadrata, nubiana and johannis. 


\title{
Dichaetomyia johannis Pont
}

\author{
(Text-figs. 6r, 64, 67)
}

Dichaetomyia johannis Pont, I967a:622, figs. 2, 5, 18. Holotype $\widehat{0}$, QueEnsLand : Byfield. In the Division of Entomology, C.S.I.R.O., Canberra.

Dichaetomyia setulifera (Stein); Malloch, I925: 323 [misidentification].

Dichaetomyia setulifera (Stein); Lee, Crust \& Sabrosky, I956 : 334 [misidentification].

Diagnosis: D. johannis is a broad bulky species and can be distinguished from the other Australian species with setulose lateral scutellar margins by the shape of the scutellum, which is broader than long (cf. Text-fig. 2), and by the position of the prsc acr setae well in front of the transverse level of prsc $d c$; by the simple unmodified mid and hind legs in the male, and by the absence of a submedian $p$ seta on fore tibia in the female.

To my previous description of this species (I $967 a: 622 \mathrm{ff}$.) I would add the following notes:

Male ori confined to lower half of frons. Auxiliary propleural seta occasionally absent, auxiliary propleural and prostigmatal setae situated below the strong setae. Tergites 4 and 5 shining, not contrasting.

Material examined. The following additional Australian material has been studied since my previous paper:

Northern Territory: Darwin, I ô. I $q$ (G. F. Hill), S.A. Mus.; Port Darwin, 2 q, iii-iv. I909 (Brunetti Coll.), BMNH; Arnhem Land, Maningrida, 5 m., Malaise-trap, I ㅇ, I8.iii.I96r (J. L. \& M. Gressitt), BMNH.

Queensland: Hamilton, Upp-Nth-Pine, I ô, i.r8go (Dept. of Mines and Agriculture), USNM [det. by Malloch as setulifera]; Gordonvale, coll ex window, I ô (J.F Illingworth), USNM [det. by Malloch as setulifera]; Cairns, coll ex corn, I $\sigma^{\hat{\alpha}}(\mathrm{J} . \mathrm{F}$. Illingworth), USNM [det. by Malloch as setulifera]; Eungella, via Mackay, 2,300 ft., 2 ㅇ, iii.I929 (F. H. Taylor), SPHTM; Townsville, 2 ô (F. H. Taylor), SPHTM; Mt. Molloy, I ô (F. H. Taylor), SPHTM; Watten, I ô. i.I929 (F. H. Taylor), SPHTM; Cairns, I $\sigma^{\wedge}(F . H$. Taylor), SPHTM; Thursday Is., I ô, 5 ㅇ (N. B. Tindale), I + , BMNH, I ô, 4 ㅇ, S.A. Mus.; Gordonvale, I ô, 27 .ii . I924 (G. Bates), SPHTM; Brisbane, in house, I 9 (A. J. Turner), SPHTM; West of Brisbane, Moggill Farm, 25 m., Malaise-trap, I ơ, I-5.ii. I96r (J. L. Gressitt), Bishop; Mareeba, Atherton Tableland, 300 m., I, ro.iii.I956 (J. L. Gressitt), Bishop; Sth. Pine R., I +, I7.i.I963 (T. Brooks), Bishop; Cairns, coll ex corn, 4 ô, I ex (J. F. Illingworth), I ô BMNH, 3 oै, I ex Bishop; Cairns, coll ex cane, I ô (J.F. Illingworth), Bishop; Cairns, coll ex cage, I ô (J. F. Illingworth), Bishop; Gordonvale, coll ex scrub, 2 ㅇ (J. F. Illingworth), BMNH and Bishop; Cairns, I o, I ex (J.F. Illingworth), Bishop; Cairns, coll ex scrub, I + ( $J$. F. Illingworth), Bishop; Cairns, ex corn, I ô (A. P. Dodd), BMNH; Barron Falls, I + , 2I.v.I958 (D. K. McAlpine), Aust. Mus.

Distribution and biology: Australia: Torres Strait (Davan Is.), Northern Territory, Queensland and New South Wales. A common species. 
D. johannis has been found in a variety of lowland habitats, up to $300 \mathrm{~m}$. : mainly in rain forest, but also in open farming country near rain forest, grassland savannah, savannah woodland, and scrub. It has been collected indoors, and amongst corn and cane. It has been found in buffalo-fly traps and blowfly traps (carrion-baited), and has been collected in Malaise-traps. It is attracted to human and other excrement, and to carrion.

Life-history and immature stages unknown.

Affinities: Only two other species of this group have the mesonotum yellow in ground-colour: peroe (Walker) from India (Madras), and caucasica Pont from Azerbaydzhan (Talysch). D. peroe differs from johannis in possessing 3 post $d c$ setae; and tergite 4 largely and tergite 5 entirely dark, tergite 5 glossy and contrasting with the shining but shagreened tergite 4. D. caucasica is very close to johannis but differs in the male by the thinly and inconspicuously whitish dusted mesonotum that lacks any vittae or pattern. D. quadrata quadrata (Wiedemann) is close to johannis in possessing 4 post $d c$ setae and shining but shagreened tergites 4 and 5 , but differs by the darkened mesonotum.

Discussion: Malloch's material of setulifera (Stein) has been studied and confirms that johannis is the species that he misidentified as setulifera (Stein).

\section{The ARMATA-GROUP}

This group includes ten Oriental and Australasian species and one subspecies, in which the scutellum is elongated, as broad as long (Text-fig. 3), and possesses dark discal setulae that extend on to the lateral surfaces at all points and even invade the ventral surface.

The armata-group possesses the following additional characters:

Mentum of proboscis dusted. Prst acr setulae 8- to 9-serial. 2 prst dc setae, 3 to 4 post dc setae. Pra seta short, about half length of 2 nd $n p l$ seta. Vallar ridge bare. Lower $s t p l$ seta more or less equidistant from the anterior and posterior ones. Hypopleuron with numerous dark setulae below spiracle and on metepisternum. Squamopleuron bare or setulose. Fore tibia with or without a submedian $p$ seta in male, always with this seta in female. Stem-vein usually bare above. Lower squama bare. Abdominal macrochaetae strikingly strong and erect on tergites 4 and 5. Male frons broad, at narrowest point broader than width of 3 rd antennal segment, ors strong, legs frequently with spines, tufts or long hairs, 5 th sternite with a shining prolongation to each lateral lobe. Elongate slim species.

This group is most closely related to the quadrata-group, from which it can be distinguished by the shape of the scutellum (cf. Text-figs. 3 and 2), by the arrangement of the $s t p l$ setae, and by the secondary male characters. It contains the most bizarre and striking species of the genus. The epicentre of the group is in Melanesia: two of the described species are Oriental (scutellaris Malloch, and malayana Malloch ssp. malayana s.s. and ssp. tamil Emden), three are Australian (longiseta Pont, norrisi Pont, and significans (Walker)), but the other five described species and about seven undescribed species are from New Guinea, the Bismarck Archipelago, the Solomon Islands, and Fiji. 


\title{
Dichaetomyia longiseta Pont
}

\author{
(Text-figs. $43,46,49$ )
}

Dichaetomyia longiseta Pont, I967a: 626, figs. Io, II, I6. Holotype $\widehat{\jmath}$, QueEnsland: 63 miles north of Marlborough. In the Division of Entomology, C.S.I.R.O., Canberra.

Dichaetomyia rigidiseta (Stein); Malloch, I924: I40 [misidentification].

Dichaetomyia rigidiseta (Stein); Malloch, I925 : 323 [misidentification].

Dichaetomyia rigidiseta (Stein); Lee, Crust \& Sabrosky, 1956:332 [misidentification].

Diagnosis: D. longiseta is a slender species and can be distinguished from the other Australian species with setulose lateral scutellar margins by the presence of 3 post $d c$ setae and the absence of setulae on the post-alar ridge between inner seta and scutellum.

I have found nothing to add to my original description and discussion of variation (I967a: 626-63I).

Material examined. The following additional Australian material has been studied since my previous paper:

QUeENSLAND: Eidsvold, I đૈ, 4.iv.I924 (Bancroft), USNM [det. by Malloch as rigidiseta]; Hamilton, Upp-Nth-Pine, I + , i.I890 (Dept. of Mines and Agriculture), USNM [det. by Malloch as rigidiseta]; Roberts Plateau, Macpherson Range, 2,5004,000 ft., I ㅇ, ii-iii.I929 (A. J. Turner), SPHTM; Brisbane, I đ) I7.xi.I9I4 ( $H$. Hacker), Qld. Mus.; West of Brisbane, Moggill Farm, 25 m., Malaise-trap, I + , 2327.i.r96I (J. L. Gressitt), Bishop; Mt. Edith Forest, I $\frac{1}{2}$ m. off Danbulla Road, I + , 6.v. Ig67 (D. H. Colless), CSIRO; Back Creek, Palen Creek State Forest, Rathdowney, I ô, I3.xii. I966 (T. G. Campbell), CSIRO.

New South Wales: Kuringgai, Sydney, I ㅇ, iv.I925 (Health Dept.), SPHTM; Araluen Valley, 3 우, I2.iii.I967 (Z. Liepa), I 우 BM, 2 우 CSIRO; Ulladulla, I $\sigma^{*}$ (F. H. Taylor), SPHTM; Blue Mountains, Springwood, I ㅇ, Io.i.I956 (D. K. McAlpine), Aust. Mus.; 30 miles S. of Singleton, Putty Road, I ô, I +, 6.ii. I968 (D. H. Colless), CSIRO.

Distribution and biology: Australia: Northern Territory, Queensland, New South Wales. An uncommon species.

This is primarily a species of rain forest and wet sclerophyll forest, from sea-level up to $\mathrm{I}, 300 \mathrm{~m}$., but it has also been found among the coarse grasses of savannah woodland and in stunted scrub near the sea-shore. It has been trapped near carrion, and collected in Malaise-traps.

Life-history and immature stages unknown.

Variation: The variation in leg chaetotaxy in this species was discussed and tabulated in my previous paper (I967a:630). Study of further material has convinced me that there is in fact only one species involved here, as originally suggested, and the variation observed in this further series of males is summarized in Table I.

Affinities: As previously mentioned (Pont, I967a:632), longiseta is closely related to rigidiseta (Stein) from New Guinea, which also has 3 post $d c$ setae and lacks setulae on the ridge between inner post-alar seta and scutellum. D. rigidiseta has, in the male sex, the $a v$ and $p v$ setae on hind femur less numerous, more robust and not at all 


\section{TABLE I}

Variation in some characters in males of Dichaetomyia longiseta Pont

\begin{tabular}{|c|c|c|c|c|c|}
\hline $\begin{array}{l}\text { Locality and } \\
\text { number of } \\
\text { specimens }\end{array}$ & $\begin{array}{c}\text { Fore tibia: } \\
\text { submedian } \\
\text { p seta }\end{array}$ & $\begin{array}{l}\text { Mid femur: } \\
p v \text { setae }\end{array}$ & $\begin{array}{l}\text { Hind femur: } \\
\text { start of } \\
a v \text { row }\end{array}$ & $\begin{array}{l}\text { Hind femur: } \\
\text { start of } \\
p v \text { row }\end{array}$ & $\begin{array}{l}\text { Hind tibia: } \\
\text { av setae }\end{array}$ \\
\hline Ulladulla (I) & $\begin{array}{l}\text { Fore legs } \\
\text { missing }\end{array}$ & $\begin{array}{l}2 \text { strong, } \\
\text { I moderate }\end{array}$ & $\begin{array}{c}\text { Basal } \frac{2}{5} \\
\text { to } \frac{1}{3}\end{array}$ & Apical $\frac{1}{2}$ & I \\
\hline Eidsvold (I) & 0 & $\begin{array}{l}\text { I strong, } \\
3 \text { moderate }\end{array}$ & Basal $\frac{1}{4}$ & Apical $\frac{1}{2}$ & 2 \\
\hline Brisbane (I) & $\begin{array}{l}\text { o (only one } \\
\text { foreleg) }\end{array}$ & 4 moderate & Basal $\frac{2}{5}$ & Apical $\frac{1}{3}$ & $\mathrm{I}-2$ \\
\hline Rathdowney (I) & I & $\begin{array}{l}\text { I strong, } \\
\text { I-2 moderate }\end{array}$ & Basal $\frac{1}{4}$ & Apical $\frac{1}{2}$ & 2 \\
\hline Singleton (I) & o & $\begin{array}{l}\text { I strong, } \\
2-3 \text { moderate }\end{array}$ & Basal $\frac{1}{4}$ & Apical $\frac{2}{5}$ & $I-2$ \\
\hline
\end{tabular}

curled, nowhere presenting a tuft-like appearance; and in the female sex, a complete row of $p v$ setae on fore femur.

Discussion: I have studied some of the material identified as rigidiseta (Stein) by Malloch (I924 : I40, and I925 : 323), and other material bearing Malloch's determination label, and can confirm that this is the species misidentified by Malloch as rigidiseta.

\section{Dichaetomyia norrisi Pont}

(Text-figs. 45, 48, 5I)

Dichaetomyia norrisi Pont, I967a : 636, figs. I, 3, 4, 6, 8, I2, I5, I7. Holotype ơ, QueEnsland: 63 miles north of Marlborough. In the Division of Entomology, C.S.I.R.O., Canberra.

Dichaetomyia armata (Stein); Malloch, I924: I40 [misidentification].

Dichaetomyia armata (Stein); Malloch, I925: 323 [misidentification].

Dichaetomyia armata (Stein); Lee, Crust \& Sabrosky, I956 : 307 [misidentification].

Diagnosis: D. norrisi is a slender species and can be distinguished from the other Australian species with setulose lateral scutellar margins, 4 post $d c$ setae and the scutellum shaped as in Text-fig. 3 by the presence of a submedian $p$ seta on fore tibia in the male sex and by the absence of several strong erect marginal setae on tergite 4 in the female. See Pont (I967a : figs. 8, I2 and I5 [see correction below under "Discussion "]).

I have found nothing to add to my original description of this species (I967a:636639).

Material examined. The following additional Australian material has been studied since my previous paper:

Queensland: Lake Barrine, I +, 25.ix. I937 (A. J. Turner), Vict. Mus.; Brisbane, I ㅇ, 30.x.I92I (H. Hacker), Vict. Mus.; Mt. Glorious, 2 ô, 3 오, I3.ii.Ig6r (L. \& $M$.

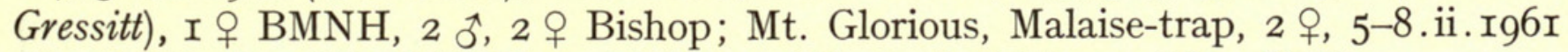
(L. \& M. Gressitt), BMNH and Bishop; West of Brisbane, Moggill Farm, $25 \mathrm{~m}$., 


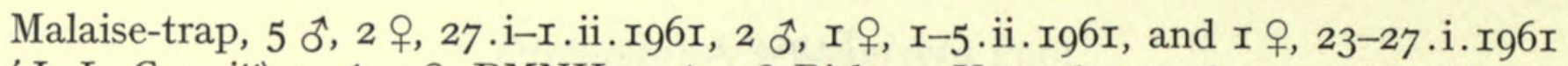
(J. L. Gressitt), 3 ठิ, I ㅇ, BMNH, 4 ô, 3 ㅇ Bishop; Yungaburra, 850 m., Ath. Tbld., Malaise-trap, I +, 9-I2.v. I96r (J. L. \& M. Gressitt), Bishop; Eidsvold, 4 o , 4.iv. I924 (Bancroft), SPHTM; Brisbane, in house, 2 ㅇ (A.J. Turner), SPHTM; Brisbane, I 우 (A. J. Turner), SPHTM; Brisbane, I ㅇ, 26.x.I908 (H. Tryon), Qld. Dept. Pr. Ind.; Brisbane, I o, I7. iii.I935, Qld. Dept. Pr. Ind.

New South Wales: Kuringai Chase, W/A Trapping, 2 +, I2-I5. viii and 23-26.ix.Ig63 (J. H. Avdley), SPHTM; Glenreagh, I +, I.ii.I923 (Health Dept.), USNM; Coramba-Dorrigo road, I,000 ft., I ô, 3r.i.r923 (Health Dept.), USNM; National Park, I + 4. vi.r955 (D. K. McAlpine), Aust. Mus.; Bronte, near Sydney, I +, v.r955 (D. K. McAlpine), Aust. Mus.

Distribution and biology: Australia: Queensland and New South Wales. The commonest and most generally distributed Australian species of the armata-group.

This species occurs from sea-level up to $850 \mathrm{~m}$., and is less restricted to rain forest than are significans and longiseta: in addition to rain forest, it has been collected in dry forest, savannah woodland, open farm land and on a sandy lawn. It has been trapped in blowfly traps over carrion and in Western Australian fly traps, and has been found indoors. It has been caught in Malaise-traps.

Life-history and immature stages unknown.

Variation: Some males have been seen in which there is a second fine submedian $p$ seta on fore tibia. One female, from Mt. Glorious, has a pair of median marginal setae on tergite 4 but otherwise has the characters of norrisi. On average, norrisi is a smaller fly than significans, but the specimens from Mt. Glorious are larger than is usual (length of wing $8.0 \mathrm{~mm}$.).

Affinities: D. norrisi is most closely related to significans from which it can be distinguished by the characters given in the key. The configuration of the male legs is unique in the armata-group, and it is the only species in the armata-group lacking marginal setae on tergite 4 in the female sex.

Discussion: I have studied some of the material identified as armata (Stein) by Malloch (I924: I40, and I925:323). Apart from the two males of significans (see below, p. 2I7), Malloch's material and published notes refer to norrisi.

Figure I4 in my previous paper (I967a:633) should bear the number I5 and not I4; of the two femora illustrated, the upper one is that of norrisi and the lower one that of significans.

\section{Dichaetomyia significans (Walker)}

(Text-figs. 3, 44, 47, 50)

Aricia significans Walker, I859: I07. Lectotype $\widehat{\sigma}$, ARU IsLAND. In the British Museum (Natural History), London. [Examined.] [Designation by Pont, I966a: 96].

Spilogaster helomyzina Stein, I900a: 384. Holotype o, NEw GuINEA: Waikunina. In the Museo Civico di Storia Naturale, Genoa. [Examined.] syn. n.

Spilogaster significans (Walker) de Meijere, I906: 90.

Mydaea spinipes Stein, I9I8: I84. Neotype of, ARU Island. In the British Museum (Natural

History), London. [See designation below.] syn. n. 
Dichaetomyia armata (Stein); Malloch, I929a: 405 [misidentification].

Mydaea spinipes Stein; Emden, I965: 492.

Mydaea spinipes Stein; Pont, r966a: 91.

Dichaetomyia significans (Walker) Pont, I966a: 96.

Dichaetomyia helomyzina (Stein) Pont, I966b : 384 .

Dichaetomyia significans (Walker); Pont, I967a:632, figs. 7, I3, I4.

Neotype designation for spinipes Stein. The names contraria Walker, significans Walker and spinipes Stein have previously been discussed in detail (Pont, I966a). It is not necessary to repeat the facts here, but a re-examination of the problem has led to the following conclusions.

The species that Stein described in I90r (p. I93) standing under the name contraria in the BMNH can only be one species, namely that now known as Dichaetomyia significans (Walker). His description fits this species in all details. My examination of all the relevant Wallace material also shews that significans is the only species that fits Stein's description. Stein doubtfully assigned these specimens under "contraria" to his rigidiseta, noting that they possessed 4 post dc setae whereas rigidiseta has but 3 such setae. He evidently decided later that this course was in error, and in I9I8 (p. I84) decided to name this species as "spinipes nov. sp. (contraria WLK, coll.) ", satisfied that the key characters and the description of Igor were sufficient validation of the name. His references to the hind femur in I9I8, conflicting with the rgor statements, must be due to some kind of error; apart from this, significans runs perfectly to spinipes in his key. Spinipes is in the section of the key with 4 post $d c$ setae and no $p$ seta on fore tibia. It cannot be rigidiseta, which is included in the section of the key with 3 post $d c$ setae and a $p$ seta on fore tibia Nor can it be a species of Eumyiospila Malloch, in which it has been placed by later authors, since Stein includes the species of this genus in a later part of the key (p. I85). It can only be significans, which fits his description (I90I : I93) and the key data (I9I8 : I79-I84) except that no mention is made of the hind femoral spine in I9I8. I am satisfied that there can be no other species involved here but for significans, and also that it was Stein's intention to name as spinipes the species now known as significans. I have previously stated my belief that Stein was in fact looking at the syntypes of significans, erroneously or for whatever reason placed under the series of contraria syntypes in the BMNH. This cannot be proved, and I am therefore forced to consider the type-series of "spinipes" as "lost " in the sense that it can no longer be located beyond any reasonable doubt.

I am therefore designating the male lectotype of significans as the male NEOTYPE of spinipes, and the name spinipes thus becomes a junior objective synonym of significans.

Diagnosis: D. significans is a slender species and can be distinguished from the other Australian species with setulose lateral scutellar margins, 4 post $d c$ setae and the scutellum shaped as in Text-fig. 3 by the absence of a submedian $p$ seta on fore tibia in the male sex and by the presence of several strong erect marginal setae on tergite 4 in the female. See Pont (I967a : figs. 7, I3 and I4 [see correction below, under "Discussion "]).

I have found nothing to add to my redescription of this species (I967a:632-636). 
Material examined. Lectotype $\hat{\delta}$ and paralectotype + of significans, and neotype $\widehat{o}$ of spinipes, Aru Island (A.R. Wallace), BMNH.

Holotype of helomyzina, New Guinea: Waikunina, vi.I89o (L. Loria), Genoa. The following material has been studied since my previous paper:

QueEnsland: Kuranda, 350 m., rain forest, I ㅇ, 6.v.rg6r (L. \& M. Gressitt), Bishop; Cape York, Top Rocky Yard, Rocky R., N.E. of Coen, I50 m., I ㅇ, 30.iv. I96I (L. \& M. Gressitt), Bishop; Cairns, I ㅇ, I2.v. I938 (F. H. Taylor), SPHTM; Kuranda, I 우 (F. P. Dodd), CSIRO; Mt. Molloy, I ơ (F. H. Taylor), SPHTM; Palm Is., I oै (F. H. Taylor), SPHTM; Claudie River near Mt. Lamond, I J, 3.vi.Ig66 (D. K. McAlpine), Aust. Mus.; Mulgrave River 4 miles W. of Gordonvale, I ㅇ, 2I.v. Ig66 (D. K. McAlpine), Aust. Mus.; Carmila, I +, I3.v.r927, Qld. Dept. Pr. Ind.

Buru Is.: Station 5, I ㅇ, iv.I92I (L. J. Toxopeus), Amsterdam [det. by Malloch as armata].

Misool Is.: i 우 (A. R. Wallace), BMNH.

West IrIAn: Merauke, I 9 , I904-I905 (Nieuw. Guinea Expeditie), Amsterdam; Manokwari, I ô, 2.v.I903, Amsterdam [det. by de Meijere as ?significans]; Sentani, $90+$ m., 2 ๙ิ, I5 \& I6. vi. I959 (T. C. Maa), Bishop; Vogelkop, Manokwari, 75 m., I ô, 2I.vii.I957 (D. E. Hardy), BMNH; Hollandia area, W. Sentani, Cyclops Mts., I50250 m., I ठै, I7.vi.I959 (J. L. Gressitt), Bishop; Nabire, S. Geelvink Bay, I-20 m., Malaise-trap, I ô, 8.vii.Ig62 (J. L. Gressitt \& J J. Sedlacek), BMNH; Nabire, S. Geelvink Bay, 0-30 m., Malaise-trap, 2 + , 2-9.vii.I962 (J. L. Gressitt), Bishop; Hollandia area, W. Sentani, Cyclops Mts., 90 m., Malaise-trap, I ô, 22.vi.r959 (Gressitt \& Maa), Bishop; Vogelkop, Fak Fak, S. coast of Bomberai, Io-Ioo m., I + , II.vi.I959 (T.C. Maa), Bishop; Lake Sentani, 50 m., I ㅇ, I2.vii.I957 (D. E. Hardy), Bishop; Biak Island, Mangrowawa, 50-I0o m., I ô, 29.v.I959 (T. C. Maa), Bishop; Baie du Geelvink, I ô, I878 (Raffray et Maindron), Paris.

N.E. New Guinea: Nineia, Morobe District, I,500 ft., I ô, v. I96o (B. McMillan), BMNH; Morobe District, Wau, 3,500-4,000 ft., 2 ㅇ, I4-23.v.I965 (R. W. Crosskey), BMNH; Wewak, I ㅇ (F. H. Taylor), SPHTM; Wewak, I ô, I 오, SPHTM; Angoram, Sepik River, I +, x.I959 (R. Pullen), CSIRO; Lower Sepik River, I + , x.I959 $(R$. Pullen), CSIRO; May R., Patrol Station, Ioo m., fresh dung, I ô, 2.vi.I963 $(R$. Straatman), Bishop; Minj, Western Highlands, I ô, I ㅇ, 8-r3.ix.I959 (T. C. Maa), ô BMNH, + Bishop; Wampit V. near Gurakor Village, 950 m., near Wau, I $q$, 7. vii. I957 (D. E. Hardy), BMNH; Wau, Morobe District, I,200 m., I + , II-I4.ix. I96I, and light-trap, I + , 2I.vii.rg6r (J. Sedlacek), Bishop.

Papua: Central District, Brown River, I ô, 7.v.I965 (R. W. Crosskey), BMNH; Central District, Kapogere, 60 m. S.E. of Port Moresby, 2 ô, I + , 3.v.rg65, and I $\sigma^{4}$,

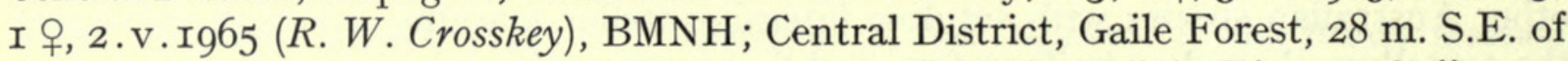
Port Moresby, I ㅇ, 5.v.I965 (R. W. Crosskey), BMNH; Vailala River, I ㅇ, ii.I922 (G. H. Murray), CSIRO; Aroana Estate, Aroa River, I o , 7.xii. I967 (D. K. McAlpine), Aust. Mus.; Eastern Highlands, South Okapa, Okasa, 4,560 ft., I ô, 25 .vi. I964 ( $R$. Hornabrook), CSIRO; Daradae Plain, $500 \mathrm{~m} ., 80 \mathrm{~km}$. N. of Port Moresby, secondary forest, I ô, 5.ix.I959, and I ô, 4.ix.I959 (T. C. Maa), Bishop; Western District, 
Oriomo Govt. Sta., Malaise-trap, 2 +, 26-28.x.Ig6o (J. L. Gressitt), BMNH and Bishop; Popondetta, 60 m., Malaise-trap, I +, 2.ix. Ig63 (J. Sedlacek), Bishop.

Bismarck ARchipelago: Manus Island, Lorengau, I-75 m., I + , 28.vi.I959 (J. L. Gressitt), Bishop; Mussau Island, Talumalaus, Malaise-traps, I + , 2I.i.I962, and I , , I.ii. I962 (Noona Dan Exped. I96I-62), BMNH and Copenhagen; New Britain, Keravat, I35 m., 2 9, 20-25.xi.I959 (T. C. Maa), BMNH and Bishop; New Britain, Vaisisi, I +, 9.vii.Ig62 (Noona Dan Exped. I96I-2), Copenhagen; New Britain, Valoka, I + , 7.vii. I962, and I + , Io.vii.Ig62 (Noona Dan Exped. I96I-62), Copenhagen.

Distribution and biology: Australia: Queensland. Buru Is., Aru Is., Misoöl Is., New Guinea (West Irian, N.E. New Guinea, Papua), and Bismarck Archipelago (New Britain, Manus and Mussau Is.). An uncommon species in Australia.

This species occurs up to $350 \mathrm{~m}$. in Australia, and is usually restricted to rain forest. It has been caught at a dairy farm, near rain forest, in a buffalo-fly trap.

In New Guinea it occurs from sea-level up to I,520 m.

Life-history and immature stages unknown.

Variation: Australian specimens of this species are very constant in structure, but some variation has been noted in non-Australian material. One male (Biak Island) has a submedian $p$ seta on each fore tibia, but is otherwise identical with significans. New Guinea females often have the ventral setulae in the basal half of hind femur very reduced or vestigial, and one female (Manus Is.: Lorengau) lacks them completely.

Affinities: D. significans is most closely related to norrisi from which it can be distinguished by the characters given in the key (p. 20I). In New Guinea and the Bismarck Archipelago it is the only species of the armata-group with a pale mesonotum and a hind femoral spine in the male, and it is replaced in the Solomon Islands by some undescribed species.

Discussion: Although the characters ascribed by Malloch (I924 : I40, and I925 : 323) to armata (Stein); Malloch in his key and notes are those of the species I have described as norrisi, I have seen two Australian males of significans identified as armata by Malloch.

I have seen the male doubtfully identified by de Meijere as significans (I906 : 90) and can confirm that this identification is correct. I have also seen the female from Buru identified by Malloch as armata (I929a: 405) and find that it is significans.

Figure 15 in my previous paper (I967a:633) should bear the number I4 and not I5: of the two femora illustrated, the upper one is that of norrisi and the lower one that of significans.

\section{THE IMPAR-GROUP}

This small group includes six Oriental and Australasian species in which there are 4 post $d c$ setae, the first of which is very reduced and only about twice as long as a ground-setula; consequently the first strong post $d c$ seta (the true second) is closer to the $d c$ behind it than to suture or, occasionally, midway between this $d c$ and the suture; and, at the same time, squamopleuron bare and fore tibia without a submedian $p$ seta. 
The impar-group possess the following additional characters:

Hypopleuron bare on beret and below spiracle, with hairs on metepisternum. Disc of scutellum with a few (up to six) setulae descending just below the level of the strong setae, otherwise bare laterally and ventrally. Pra seta well-developed but short, half length of 2nd $n p l$ seta. Stem-vein bare above. 2 prst $d c$ setae. Prst acr setulae $5^{-}$to 7 -serial. Vallar ridge bare. Lower squama bare on disc. Mentum of proboscis dusted.

The group contains only three described species, and the three new species that are described below. D. parimpar is confined to Australia; D. breviseta is distributed from Australia, through southern New Guinea and New Britain to the Solomon Islands, as far east as Malaita Is.; $D$. parviseta is confined to the extreme eastern islands of the Solomon group, Ugi and San Cristobal. These three Australasian species are described below, and parviseta is described as new in this paper because it is so closely related to the other two that its relationship and distinctive characters are best emphasized comparatively by reference to the other species.

The other three species in this group differ from parimpar, breviseta and parviseta as follows:

D. impar (Stein), known only from the syntypic series from Java, resembles breviseta most closely in having mesonotum yellow, and abdomen with tergites 4 and

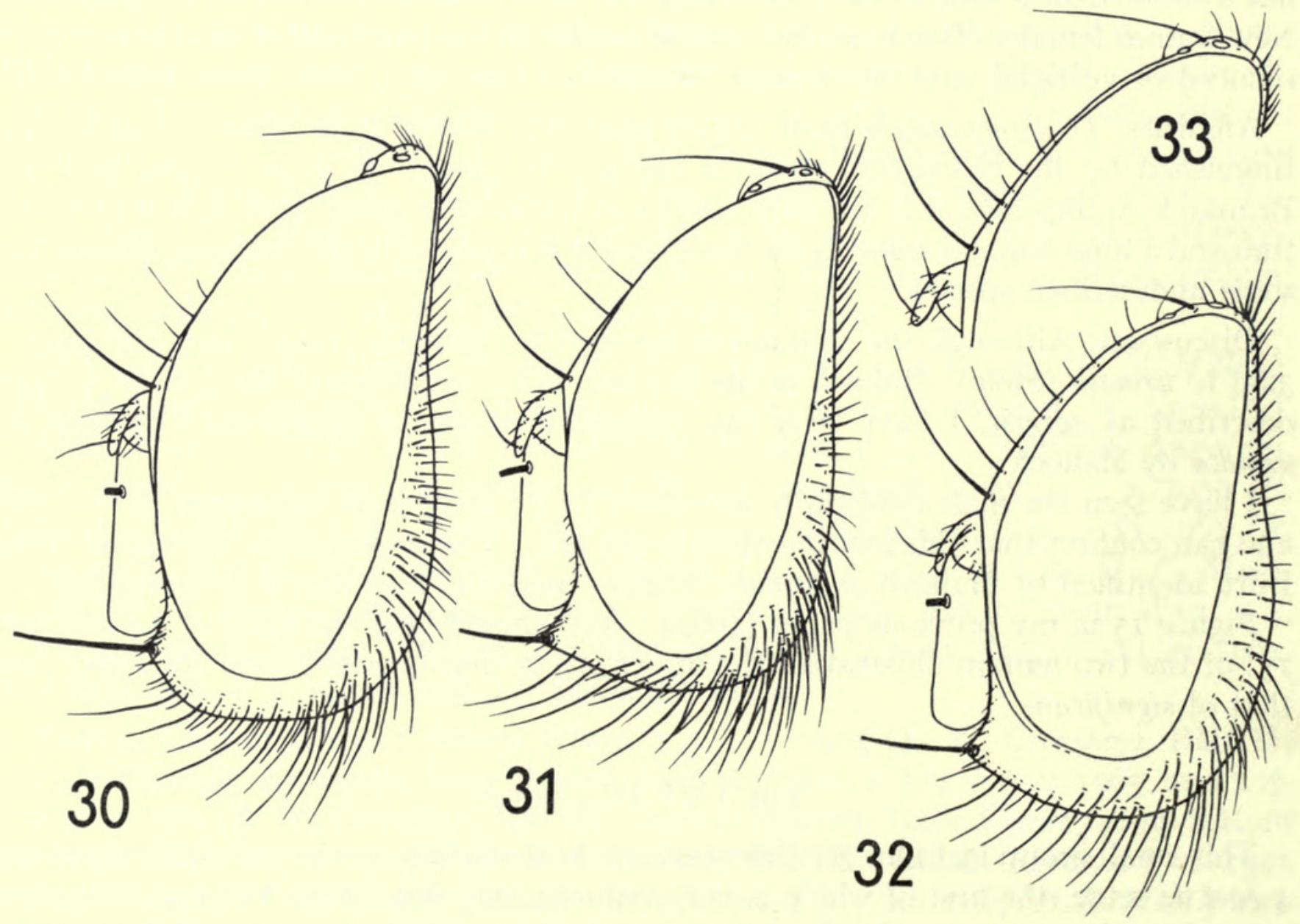

Figs. 30-33. Dichaetomyia impar group, head, ô, lateral view, of: 30, D. parimpar sp. n. (holotype); 3I, D. parviseta sp. n. (holotype); 32, D. breviseta sp. n. (Q, Yeppoon Io.v. 55 , paratype); $33, D$. breviseta, frons only (holotype). 
5 infuscated but basal tergites yellow. Females differ from breviseta by the absence of $a v$ and $p v$ setae or setulae in the basal half of mid and hind femora, but it is anticipated that the male of impar, when discovered, will differ rather more significantly from that of breviseta.

D. canivitta (Walker), known only from the female holotype from Aru Island, has the mesonotum largely infuscated, with a conspicuous broad light grey dusted median vitta from neck to well behind suture; mainly yellow pteropleural setulae; brown femora and tibiae; creamy white squamae; hind femur with some strong av setae in basal half.

D. pallens (Stein), from India and Ceylon, has the mesonotum except for humeri, pleura and scutellum dark in ground-colour and densely yellowish grey dusted, the mesonotum with a pair of thinly dusted paramedian vittae from neck to 3 rd post $d c$ seta; abdomen partly dark in ground-colour and densely yellowish grey dusted; hind femur of male with a complete row of $a v$ setae.

\section{Dichaetomyia impar (Stein)}

Mydaea impar Stein, I909 : 229. Lectotype , JAVA: Batavia, Moeara Antjol. In the Zoölogisch Museum der Universiteit van Amsterdam. [See designation below.]

Lectotype designation: Stein described this species from two females, one of which is now in the Zoölogisch Museum der Universiteit van Amsterdam and the other in the Zoologisches Museum der Humboldt-Universität zu Berlin. I have been able to study both syntypes. Both are in excellent condition, and each bears the data "E. Jacobson, Moeara Antjol, Batavia, Dec. I907" and Stein's determination label. I have labelled, and designate herewith, the Amsterdam female as LECTOTYPE and the Berlin female as paralectotype.

Malloch (I925: 327) has recorded impar from Australia. I have studied a number of Australian specimens so identified by him, and find that they are referable to parimpar sp.n. True impar is in fact most closely related to breviseta sp. n. and differs principally by the absence of $a v$ and $p v$ setae or setulae in the basal half of mid and hind femora. D. impar is still known only from the type-series from Java.

\section{Dichaetomyia parimpar sp. $\mathrm{n}$.}

$$
\text { (Text-figs. 30, 34, 35, 36, 37, 52, 55, 58) }
$$

Dichaetomyia impar (Stein); Malloch, I925 : 327 [misidentification].

Dichaetomyia impar (Stein); Lee, Crust \& Sabrosky, I956 : 32 I [misidentification].

Diagnosis: D. parimpar can be distinguished from other species of the impar-group with a yellow mesonotum by the ground-colour of the abdomen, in which tergites $\mathrm{I}+2$ and 3 may be yellow or black fasciate or entirely black but in which tergites 4 and 5 are always yellow, and by the weaker abdominal macrochaetae. In addition the male can be distinguished by the white-dusted prst markings on mesonotum and by the narrow frons, at narrowest point less than diameter of anterior ocellus, with interfrontalia completely obsolete on median third or more. The female can be 
reliably separated from that of breviseta by the abdominal characters, but is otherwise almost indistinguishable.

o. Head: Profile as in Text-fig. 3o. Eyes virtually bare, with only the usual microscopic pubescence. Ocellar setae quite weak, only half length of anterior prst dc. Vertical setae short, only slightly longer than the adjacent post-ocular setulae. Post-ocular setulae very short, with several scattered setulae below the upper row, most of which are black. Parafrontalia, parafacialia and face silvery white pruinose; genae black in ground-colour, brownish grey pruinose. Interfrontalia, viewed from below, with the visible parts grey pruinose. Parafrontalia slender throughout, at lunula equal to a little over diameter of anterior ocellus. Interfrontalia reduced, two small triangles visible before ocellar tubercle and at lunula. 4-5 pairs of rather weak inclinate ori on lower two-fifths of frons, the upper pair hair-like; I-2 pairs of hair-like reclinate ors just before ocellar tubercle. Antennae and basal third of arista yellow; 3rd segment weakly to conspicuously infuscated beyond arista, white pruinose. 3rd segment three times as long as broad, in frontal view reaching epistoma. Arista with long regular plumosity, the longest of which almost equals length of 3 rd antennal segment. Parafacialia slender, opposite insertion of arista equal to diameter of anterior ocellus. Parafacialia and genae bare. In lateral view, parafrontalia and parafacialia largely invisible; vibrissal angle projecting slightly beyond profrons. Genae slender; the depth below lowest eye-margin almost equal to width of 3rd antennal segment. Peristomal setae rather dense, especially behind. Beard black, with some golden setae. Facial ridges with short hairs ascending to midway level of 3 rd antennal segment. Mentum of proboscis light brown to brown. Palpi yellow, brown in basal third to half, entirely yellow in some males; compressed, quite slender, weakly clavate towards tips. Thorax: Thorax and scutellum entirely yellow in ground-colour. Scutellum undusted, pleura virtually undusted. Anterior spiracle pale yellow. Mesonotum with the ground-setulae rather short and sparse, except those between the $d c$, black unless otherwise stated; some pleural ground-setulae paler towards tips. $A c r o+\mathrm{I}$, the single ( $p r s c)$ pair well developed, slightly closer to each other than to the $d c$. $2 h$, the outer one one and a half times length of the inner one. $2 p h$, the posterior one twice length of the anterior one. $2 \mathrm{ia} .2 \mathrm{sa}$, the posterior one weak. Post-alar callus with 2 setae, with setulae present on the ridge between inner seta and scutellum. Post-alar declivity with or without a few golden hairs. Supra-squamal ridge bare. Prosternum golden setulose, rarely with a few brown setulae in front. Propleural depression bare. I propleural and I prostigmatal seta, each with an auxiliary seta below; the former surrounded by few, the latter by numerous, entirely or predominantly dark setulae. Ist $n p l$ longer and stronger than 2nd; disc of notopleuron with setulae. Mesopleuron with 4 strong setae in caudal row, and a conspicuous black setula in upper anterior corner. Infra-alar bulla yellow, bare. Pteropleuron with the setulae on sub-alar ridge confined to anterior part, a few descending down to sternopleural and hypopleural margins and becoming paler towards tips, the lowest ones apparently dark yellow or brown at bases but none wholly yellow. $S t p l \mathrm{I}+2$, the lower one usually weaker than anterior one, and only slightly closer to posterior one than to anterior one. Hypopleuron with the hairs on metepisternum pale, rarely brown. Metathoracic spiracle small, subtriangular, with a row of black setulae on lower margin. Scutellum with a very strong apical and sub-basal lateral pair of setae. Disc with rather short dense setulae, a few stronger ones apically and laterally. Legs: Yellow; tarsi yellow, $5^{\text {th }}$ and rarely $4^{\text {th }}$ segments brown. Tarsi unremarkable. Fore femur without $a v$ setae, with a complete row of $p v$ setae. Mid femur with or without a few fine $p v$ setae in basal third, none of which is as long as femoral depth, otherwise without $a v$ or $p v$ setae; I $a$ and $3 d-p$ preapical setae. Mid tibia with $2 p$ setae. Hind femur with 3-5 longer $a v$ and $p v$ setulae in basal third, and with 4-5 preapical av setae, the basal ones may be so reduced as to be almost absent, or may be well developed and numerous, in some cases almost forming a complete row on the $a v$ surface; $a d$ row complete; I $d$ and I $p d$ preapical setae. Hind tibia with I $a d$ and I (rarely 2) $a v$ seta slightly apicad of it; some of the $p d$ ground-setulae more erect in apical half; $a d$ and $d$ preapical setae subequal, and subequal to tibial depth. Wings: Yellowish tinged. Epaulet and basicosta yellow. Subcostal sclerite bare. Costa setulose ventrally as far as the apex of vein 2, the spine inconspicuous. Stem-vein with a few dark hairs below. Small cross-vein placed 
below or slightly apicad of the point where vein I enters costa. Hind cross-vein oblique, bowed to weakly sinuate. Vein I bare. Vein 3 bare above; below with a few setulae on the node at base and just beyond. Vein 4 inclined weakly forward towards vein 3 in apical section. Squamae rather deep yellow, margins of upper one concolourous with disc, margins of lower one creamy or concolourous, fringes pale. Knob of halteres yellow. Abdomen: Sternites yellow. In posterior view, tergites hardly dulled by dust, subshining; finely shagreened and not glossy, this being particularly noticeable on the black areas. Genitalia: Text-figs. 52, 55, 58. Measurements: Length of body, 7·0-7.5 $\mathrm{mm}$. Length of wing, $6 \cdot 5-7 \cdot 0 \mathrm{~mm}$.

․ Differs from the male as follows. Head: Eyes broadly separated; frons at middle slightly less than an eye-width, broadening gradually towards lunula. Upper inner eye-facets not enlarged. Ocellar setae strong, almost equal to 2 nd prst $d c$ seta, directed forwards and slightly outwards. The incurved vti not much longer than the outcurved vte; pvt weak, outcurved. Parafrontalia silvery white pruinose below, the pruinosity thinner and then greyer or even yellowish grey in upper half, subshining black alongside ocellar tubercle; parafacialia whitish grey, face more grey, genae brownish grey. Interfrontalia black in ground-colour, reddish in immature specimens; viewed from below, wholly brownish grey pruinose; frontal triangle visible as a subshining black streak extending $\frac{3}{5}$ distance from anterior ocellus to lunula. Parafrontalia slender, broadening gradually towards lunula; at middle almost twice diameter of anterior ocellus, at lunula as broad as width of 3 rd antennal segment. Interfrontalia with the margins weakly convex, broadest at middle of frons, at lunula broader than a parafrontale, bare. 4-5 pairs of well developed inclinate ori on lower two-thirds of frons, with a few interstitials, the lowest pair very strong; 2 pairs of reclinate ors, the upper stronger than the lower and placed closer to it than to vti; parafrontalia otherwise with short proclinate setulae on whole length. Parafacialia broader, opposite insertion of arista slightly broader than diameter of anterior ocellus, hardly tapering below. Thorax: Viewed from above and behind, mesonotum and scutellum undusted except for very faint traces of the white-dusted vittae of the male at neck. Lower stpl slightly weaker than the anterior one. Scutellum with 4-6 setulae below the level of the strong setae. Legs : Mid femur with 3-4 $d-p$ preapical setae. Hind femur with 2-5 preapical av setae. Measurements: Length of body, 6.5-7.5 $\mathrm{mm}$. Length of wing, $6 \cdot 0-7 \cdot 0 \mathrm{~mm}$.

Holotype ot. Queensland: Mount Spec, 2,900 feet, 22.iv.I955 (K. R. Norris), CSIRO.

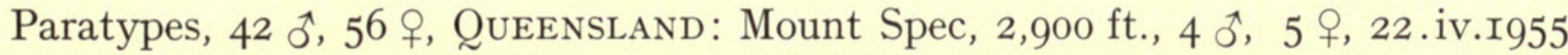

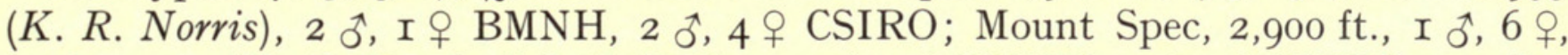
22.iv. I955 (K. R. Norris \& I. F. B. Common), 2 ㅇ BMNH, I ô, 4 + CSIRO; 4 miles S. of Atherton, I ô, 2.v.I955 (K. R. Norris), CSIRO; I mile E. of Kuranda, I o, I9.iv. I964 (I. F. B. Common \& M. S. Upton), BMNH; 3 miles N. of Kuranda, I + , 24.iv. I955 (K. R. Norris), CSIRO; Daintree, at light, 8 p.m., I ô, 3.ix.I959 (R. Laird), CSIRO; Coomera River, Lamington Nat. Park, I,200 ft., I ô, 28.v. I966 ( $Z$. Liepa), CSIRO; Highvale, I4 miles N.W. of Brisbane, I đో, 27 .xii. I959 (R. Straatman), CSIRO; I2 miles S. of Ravenshoe, 8 ㅇ, 4.v.I955 (K. R. Norris), 3 BMNH, 5 CSIRO; Byfield, I ㅇ, Io.v.I955 (Common \& Norris), CSIRO; I4 miles S.W. of Sarina, I ㅇ, 8.v.I955 (K. R. Norris), CSIRO; Palm Is., I ㅇ, 20.xii.I930-6.i.I93I (I. M. Mackerras), CSIRO; Mt. Bartle Frere, east base, 80 ft., 2 \%, 24 and 25.iv. I955 (K. R. Norris), CSIRO; I \& (Bancroft), BMNH [det. by Malloch as impar]; Tambourine Mts., I ㅇ, I8-25.v. I935 (R. E. Turner), BMNH; Kuranda, I + (F. P. Dodd), BMNH; Kuranda, 3 ô, ix.IgIo (Brunetti Coll.), BMNH; Kuranda, I ô, x. I9Io (Brunetti Coll.), BMNH; Mt. Tambourine, I ô (A. M. Lea), S.A. Mus.; Mt. Glorious, 2 , I3.ii.I96I (L. \& M. Gressitt), BMNH and Bishop; Mt. Glorious, 2 f, I + , Malaisetrap, 5-8.ii.rg6r (J. L. \& M. Gressitt), Bishop; Mt. Glorious, sclerophyll forest, I $q$, 
I6-20.ii.rg6r (L. \& $M$. Gressitt), Bishop; Mt. Glorious, 600 m., rain forest, I ㅇ, 28.ii-6.iii.Ig6r (L. \& M. Gressitt), BMNH; Mt. Glorious, rain forest, I §ै, I +, I3I6.ii.Ig6r (L. \& $M$. Gressitt), ô BMNH, ㅇ Bishop; Hamilton, Upp-Nth-Pine, I ô, xii.I889 (Dept. of Mines and Agriculture), USNM [det. by Malloch as impar]; Malanda, I + $(G . F$. Hill), USNM [det. by Malloch as impar]; Eungella, via Mackay,

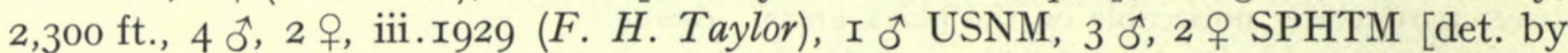
Malloch as impar]; Roberts Plateau, Macpherson Range, 2,500-4,000 ft., I o, iiiii.I929 (J. Turner), SPHTM; Canungra, I + , 20.ii.I955 (Standfast), CSIRO; Mossman Gorge, I ô, 24.iv. I967 (D. H. Colless), CSIRO; 5-8 m. Mt. Lewis Road off Mossman-Mt. Mulloy Road, I $\hat{0}$, I + , 22.iv. I967 (D. H. Colless), CSIRO; Whitfield Range Forest Reserve, Cairns, I ô, I9.iv. I967 (D. H. Colless), CSIRO; Kuranda, I o (F. P. Dodd), SPHTM; Brisbane, in house, 2 ㅇ (A. J. Turner), SPHTM; Brisbane, in house, I +, xii.I928 (A.J. Turner), SPHTM; Mount Spec, 2 ô, 2 ㅇ, I.iv.rg65 (D. E. Havenstein), CSIRO; Mulgrave River, 4 miles W. of Gordonvale, I +, 2.i.I967 (D. K. McAlpine), Aust. Mus.; Goondi Hill, Innisfail, I đૈ, 7.x.I955 (R. Dobson), Aust. Mus.

New South Wales: Manly Reservoir, Sydney, I ô, 24.iv.rg6r (D. H. Colless), CSIRO; Kangaroo Valley, $2 \hat{\jmath}, 2$ 우, 23. iii.I96I (D. H. Colless), ô 우 BMNH, ô 우 CSIRO; Palm Creek, Royal National Park, I ô, 2 ㅇ, 2.i.I962, CSIRO; Clyde Mt., east slope, I ô, 5.iv. I96o (Z. Liepa), BMNH; Killara, I ô, 27.i.I936 (M. F. Day), CSIRO; Dorrigo, I ô, I o (W. Heron), S.A. Mus.; Kuringai Chase, I ㅇ, 23-26.ix. I963 (J. H. Avdley), SPHTM; Upper Allyn, near Eccleston, I J, 4.v.Ig67 (D. K. McAlpine), Aust. Mus.; Springwood, Blue Mountains, larva in rotting wood, 30.i. I956, adult em. Ir.ii.I956, I $\sigma^{\wedge}$ with puparium (D. K. McAlpine), Aust. Mus.; N. Bondi, I 0 , 4.vi.rg62 (K. Kota), Aust. Mus.; Mt. Gibraltar, National Park, eastern scarp, $c$. 3,000 ft., I + , 24.ii. 1965 (D. K. McAlpine), Aust. Mus.; Minnamurra Falls, I ô, 29.i. I968 (Z. Liepa), CSIRO; Dorrigo Nat. Park, I ô, I +, I2.ii. I968 (D. H. Colless),

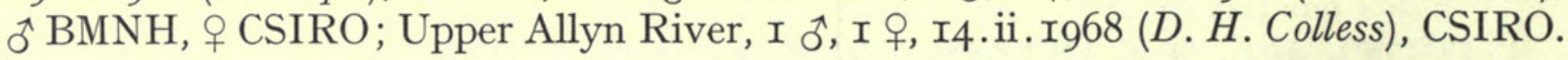

Not paratypes, QueEnsland: Atherton, I đ^, 6.x.I959 (G. Ettershank), Qld. Dept. Pr. Ind. New South Wales: Sydney, I +, 6.xi.rg22 (Health Dept.), SPHTM.

Distribution and biology: Australia: Queensland and New South Wales. A common species.

This species is most common in rain, sclerophyll and eucalyptus forest, and occurs from sea-level up to about $\mathrm{I}, 200 \mathrm{~m}$. It has also been found in dry forest and in open agricultural country. It has been trapped in carrion-baited blowfly traps, and collected in Malaise-traps. It has been attracted to light and been caught indoors.

The puparium has been found in rotting wood: the larva was found by D. K. McAlpine in a rotting log in wet sclerophyll forest just above rain forest. The larva is apparently saprophagous (description below).

Puparium (Text-fig. 34): $6 \mathrm{~mm}$. Dark reddish brown. Anterior spiracles small, conical; posterior spiracles apical (Text-fig. 34). Perianal plate as in Text-fig. 36. Posterior spiracle (Text-fig. 37) with 3 slits, weakly curved; 4 very inconspicuous perispiracular glands; distance factor $2 \cdot 8$.

Larval mouth-hooks as in Text-fig. 35. Anterior rods present. Dental sclerites separate, not fused to form a median ventral arch. Anterior dorsal bridge on basal piece absent. Lateral 
hooks joined basally by a narrow chitinized bridge, from which a chitinized strip is produced cephalad.

The mouth-hooks and spiracles agree in basic structure with those of nubiana as illustrated and keyed by Emden (1965 : I9, figs. Io h and II o), with the following differences:

(I) The dental sclerites are stated by Emden to be fused to form a median ventral bridge. This is not so in parimpar.

(2) The narrow bridge connecting the lateral hooks, with its associated chitinized strip, is absent in nubiana.

(3) The distance factor for the posterior spiracles is 4.4 in mubiana whereas it is only 2.8 in parimpar.

Variation: The abdominal colour pattern is very constant and of specific value. It should be borne in mind that tergites 4 and 5 may be partially or largely discoloured by the effects of post-mortem decay of the viscera, but with care such discolouration can be distinguished from a true black ground-colour and females can be reliably separated from those of breviseta using the abdominal characters given in the key above. Vein 3 is always bare above in the female. Hind tibia usually has I av seta, but in ten of the ror specimens examined a second seta is present but only on one leg.

The colour of the palpi varies, and is broadly correlated with geographic distribution. In general the palpi are yellow, with the basal third to half brown, but some specimens have them entirely yellow and these tend to be the southern ones though a few Queensland specimens have also been seen with palpi almost entirely yellow.
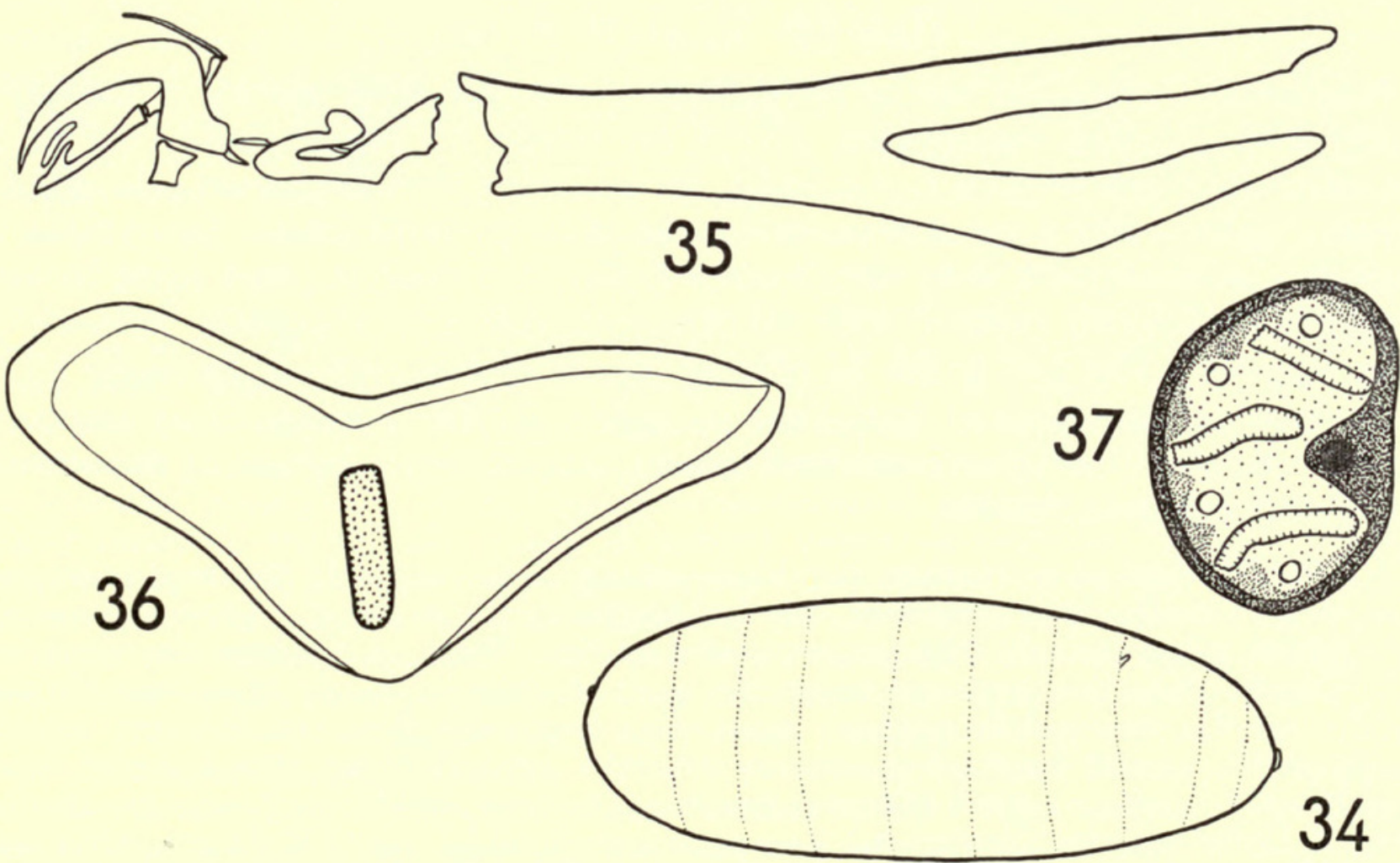

Figs. 34-47. Dichaetomyia parimpar sp. n., immature stages (N.S.W., Blue Mts, Springwood, II.ii.56, ot paratype): 34, puparium, lateral view (head to the right, dorsum above); 35 , larval mouth-hooks, lateral view; 36 , perianal plate; 37 , posterior spiracle (spiracle distance factor $=2 \cdot 8$ ). 
In leg setae, the following variation has been observed. Mid femur in basal half usually has a few $p v$ setae almost as long as femoral depth, but these vary in number and strength and may be virtually indistinguishable from the ground-setulae. The $a v$ and $p v$ setulae in basal third of hind femur also vary. In general there are three to four on each surface, quite distinct from the ground-setulae and about half femoral depth in length; sometimes they are vestigial and hardly developed, whilst in others they are very well developed, well over half femoral depth in length, quite numerous, and, on the $a v$ surface, almost forming a complete $a v$ row of setae.

The male interfrontalia is usually entirely obsolete on median third or more of frons, without even a seam indicated. In some males the seam is weakly indicated.

Affinities: $D$. parimpar is closely related to both breviseta and parviseta but may be distinguished from both by the characters given in the key and in the diagnoses of the three species. The male genitalia are more like those of breviseta than those of parviseta.

Discussion: This species was identified by Malloch (I925:327) as impar (Stein), but I have studied the syntypes of this latter species (see above, p. 2I9) and am satisfied that a distinct species is involved. I have also studied the male from Hamilton and female from Malanda, recorded as impar by Malloch (I925 : 327), and further Australian specimens so identified by him: these all belong to the present species.

\section{Dichaetomyia breviseta sp. $\mathrm{n}$.}

$$
\text { (Text-figs. 32, 33, 53, 56, 59) }
$$

Diagnosis: $D$. breviseta can be distinguished from the other species of the impargroup with a yellow mesonotum, except for impar, by the ground-colour of the abdomen, in which tergites $I+2$ and 3 are entirely yellow in ground-colour but in which tergites 4 and 5 are always entirely black in ground-colour. In addition the male can be distinguished by the broader frons, at narrowest point equal to twice diameter of anterior ocellus, with interfrontalia distinct throughout between the parafrontalia. The female can be reliably separated from that of parimpar by the abdominal colouration and from that of impar by the presence of av setulae or setae in the basal half of mid and hind femora, but otherwise females of these species are almost indistinguishable.

o. Head: Profile as in Text-fig. 32. Eyes virtually bare, with only the usual microscopic pubescence. Ocellar setae quite weak, only half length of anterior prst $d c$. Vertical setae short, only slightly longer than the adjacent post-ocular setulae. Post-ocular setulae very short, with several scattered setulae below the upper row, most of which are black. Parafrontalia, parafacialia and face silvery white pruinose; genae black in ground-colour, brownish grey pruinose. Interfrontalia, viewed from below, grey or brownish grey pruinose. Parafrontalia slender throughout, at lunula equal to a little over diameter of anterior ocellus. 4-5 pairs of inclinate ori on lower half of frons in holotype and some paratypes (Text-fig. 33), with a few hair-like interstitials, the upper I-2 pairs hair-like; in other paratypes the ori continuing as far as the ors, no gap present between them (Text-fig. 32); I pair of weak fine but distinct reclinate ors just before ocellar tubercle. Antennae and basal third of arista yellow; 3rd segment infuscated towards apex, white pruinose. 3rd antennal segment three times as long as broad, in frontal view reaching epistoma. Arista with long regular plumosity, the longest of which almost equals length of 
3rd antennal segment. Parafacialia slender, opposite insertion of arista equal to diameter of anterior ocellus. Parafacialia and genae bare. In lateral view, parafrontalia and parafacialia visible though slender; vibrissal angle projecting slightly beyond profrons. Genae slender; the depth below lowest eye-margin almost equal to width of 3 rd antennal segment. Peristomal setae rather dense, especially behind. Beard black, with some golden setae. Facial ridges with short hairs ascending to midway level of 3 rd antennal segment. Mentum of proboscis brown. Palpi yellow, sometimes brown in basal quarter; compressed, quite slender, weakly clavate towards tips. Thorax: Thorax and scutellum entirely yellow in ground-colour. Scutellum undusted, pleura virtually undusted. Anterior spiracle pale yellow. Mesonotum with the ground-setulae rather short and sparse, except those between the $d c$, black unless otherwise stated; some pleural ground-setulae paler towards tips. $A c r$ o $+\mathrm{I}$, the single (prsc) pair well developed, slightly closer to each other than to the $d c .2 h$, the outer one one and a half times length of the inner one. $2 p h$, the posterior one twice length of the anterior one. 2 ia. 2 sa, the posterior one weak. Post-alar callus with 2 setae, with setulae present on the ridge between inner seta and scutellum. Post-alar declivity usually with hairs. Supra-squamal ridge bare. Prosternum golden setulose. Propleural depression bare. I propleural and I prostigmatal seta, each with an auxiliary seta below; the former surrounded by few, the latter by numerous, dark setulae. Ist $n p l$ longer and stronger than 2nd. Mesopleuron with 4 strong setae in caudal row, and a conspicuous black setula in upper anterior corner. Infra-alar bulla yellow, bare. Pteropleuron with the setulae on sub-alar ridge confined to anterior part, a few descending down to sternopleural and hypopleural margins and becoming paler towards tips, the lowest ones apparently dark yellow or brown at base but none wholly yellow. Stpl I +2 , the lower one weaker than anterior one, sometimes subequal to it, and only slightly closer to posterior one than to anterior one. Hypopleuron with the hairs on metepisternum pale or dark. Metathoracic spiracle small, subtriangular, with a row of black setulae on lower margin. Scutellum with a very strong apical and sub-basal lateral pair of setae. Disc with rather short dense setulae, a few stronger ones apically and laterally. Legs: Yellow; tarsi yellow, $5^{\text {th }}$ and usually $4^{\text {th }}$ segments brown. Tarsi unremarkable. Fore femur without $a v$ setae, with a complete row of $p v$ setae. Mid femur with a few fine $p v$ setae in basal third, none of which is as long as femoral depth, sometimes very reduced, otherwise without $a v$ or $p v$ setae; I $a$ and $3 d$-p preapical setae. Mid tibia with $2 p$ setae. Hind femur with $3-5$ longer $a v$ and $p v$ setulae in basal quarter, and with 2-4 preapical $a v$ setae; $a d$ row complete; I $d$ and I $p d$ preapical setae. Hind tibia with I $a d$ and I (rarely 2) weaker $a v$ seta slightly apicad of it; some of the $p d$ ground-setulae more erect in apical half; $a d$ and $d$ pre-apical setae subequal, and subequal to tibial depth. Wings: Yellowish tinged. Epaulet and basicosta yellow. Subcostal sclerite bare. Costa setulose ventrally as far as the apex of vein 2, the spine inconspicuous. Stem-vein with a few dark hairs below. Small cross-vein placed below the point where vein I enters costa. Hind cross-vein oblique, bowed to sinuate. Vein I bare. Vein 3 bare above; below with a few setulae on the node at base and just beyond. Vein 4 inclined weakly forward towards vein 3 in apical section. Squamae rather deep yellow, margins of upper one concolourous with disc, margins of lower one creamy or concolourous, sometimes squamae and margins largely brownish, fringes pale. Knob of halteres yellow, or sometimes brown. Abdomen: Sternites yellow. In posterior view, tergites hardly dulled by dust, subshining; finely shagreened and not glossy, this being particularly noticeable on the apical black areas. Macrochaetae poorly developed and short, but rather stronger than in parimpar, especially the median marginals of tergite 4 , and tergite 5 with more numerous discals than in parimpar. Genitalia: Text-figs. 53, 56, 59. Measurements: Length of body, 6.5-7.5 $\mathrm{mm}$. Length of wing, $6 \cdot 0-7 \cdot 0 \mathrm{~mm}$.

ㅇ. Differs from the male as follows. Head: Eyes broadly separated; frons at middle slightly less than an eye-width, broadening gradually towards lunula. Upper inner eye-facets not enlarged. Ocellar setae strong, almost equal to 2 nd prst $d c$ seta, directed forwards and slightly outwards. The incurved $v t i$ not much longer than the outcurved $v t e$; pvt weak, outcurved. Parafrontalia silvery white pruinose below, almost entirely brownish grey pruinose above part at lunula or above lower third, subshining black alongside ocellar tubercle; face more grey, genae brownish grey. Interfrontalia black in ground-colour, sometimes reddish at lunula; viewed from below, wholly brownish grey pruinose; frontal triangle visible as a subshining black streak ex- 
tending three-fifths distance from anterior ocellus to lunula. Parafrontalia slender, broadening gradually towards lunula; at middle almost twice diameter of anterior ocellus, at lunula as broad as width of 3 rd antennal segment. Interfrontalia with the margins weakly convex, broadest at middle of frons, at lunula broader than a parafrontale, bare. 4 pairs of well developed inclinate ori on lower two-thirds of frons, with a few interstitials, the lowest pair very strong; 2 pairs of reclinate ors, the upper one stronger than the lower and placed closer to it than to vti; parafrontalia otherwise with short proclinate setulae along most of length. Parafacialia broader, opposite insertion of arista slightly broader than diameter of anterior ocellus, hardly tapering below. Thorax: The Howard Springs + have the disc of scutellum partially to largely infuscated. Legs : $4^{\text {th }}$ and $5^{\text {th }}$ tarsal segments brown. Fore tibia in a Yeppoon o with a small $p$ seta on each side. Hind femur with the basal $a v$ and $p v$ setulae scarcely developed, rather long or even longer than in male in some ㅇ. Wings: Hind cross-vein sinuate. Abdomen: Only tergite I +2 yellow in Howard Springs ㅇ. Measurements: Length of body, 5.5-7.0 mm. Length of wing, 5.0$6.5 \mathrm{~mm}$.

\section{Holotype ô. Queensland: Yeppoon, Io.v.r955 (K. R. Norris), CSIRO.}

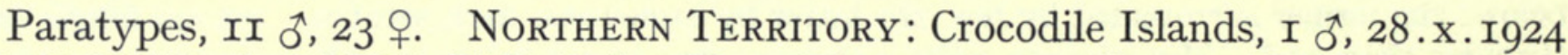
(G. H. Wilkins), BMNH; Bill's Point, Mary River, I +, 3.viii. I929 (I. M. Mackerras \& T. G. Campbell), CSIRO; Howard Springs, 3 ㅇ, I2.vi.rg64 (K. R. Norris), I

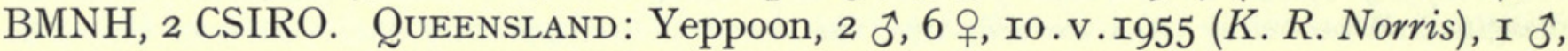

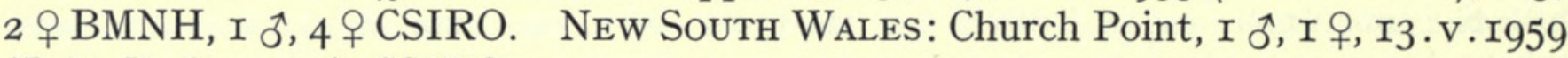
(I. F. B. Common), CSIRO.

West Irian: Merauke, sea level, r ㅇ, 26.i-ro.ii. I96o (T. C. Maa), Bishop; Biak Island, Mangrowawa, 50-Ioo m., I ô, 29.v. I959 (T. C. Maa), Bishop. N.E. NEw Guinea: Ajbom, Sepik River, I ô, 7.iii.rg64 (D. H. Colless), CSIRO. Papua: Port Moresby, Boroko, Malaise-trap, I ô, 6-7.xi.I96o (J. L. Gressitt), Bishop; Moitaka, Port Moresby, in trap, I q, iii. I962 (K. R. Norris), CSIRO.

New Britain: Keravat, I q, 23-30.vi.rg65 (R. W. Crosskey), BMNH.

Solomon Islands: Russell Is., Kaylan, I ô, 8.xi.r934 (R. A. Lever), BMNH; Nggela, Halalu, I ô, 28.x. I934 (R. A. Lever), BMNH; Vella Lavella, Pusisama, I ㅇ, xi.I964 (P. Shanahan), Bishop; Guadalcanal, Lunga River (mouth), I ô, 26.v. I944, and I + , 9.vi. I944 (H. E. Milliron), Bishop; Guadalcanal, Lunga River (bridge), I ô, 4.ix. I96o (C. W. O’Brien), Bishop; Guadalcanal, Tenaru R., 30-6o m., I o, 25 . vi. I964 (J. \& M. Sedlacek), Bishop; Malaita, Su'u, I q, iv. I933 (R. J. A. W. Lever), BMNH; New Georgia Group, Rendova Is., N.E. end, I ㅇ, r6. vii. 959 (J. L. Gressitt), BMNH; New Georgia Group, Kolombangara Is., Kukunda, S.W. coast, I-I2 m., ex fresh human excrement, 3 ㅇ, 8-II.vii. I959 (J. L. Gressitt), I BMNH, 2 Bishop; Bougainville, Arawa, 4-7 m. N. of Kieta, I +, 9-I3. vii. I965 (R. W. Crosskey), BMNH.

Distribution and biology: Australia: Northern Territory, Queensland and New South Wales. New Guinea (West Irian, N.E. New Guinea, Papua), New Britain, and Solomon Islands (eastwards to Malaita Is.). A rare species in Australia.

This is a lowland species in Australia, and has been collected in riverine rain forest and in open country.

In New Guinea it occurs up to roo $\mathrm{m}$. and has been collected in Malaise-traps. In the Solomon Islands it has been found on fresh human excrement.

Life-history and immature stages unknown. 
Variation: The description given above is based on Australian material, and the variation in Australian specimens will be briefly discussed here. New Guinea, New Britain and Solomon Islands specimens show rather more striking variation: this has not been taken into account in the description and is discussed in detail below.

In the holotype the ori are separated from the ors by a considerable gap (Text-fig. $33)$; in the male paratype from Crocodile Island, there is one setula in this gap; in the male paratypes from Yeppoon and Church Point, this gap is completely filled with fine setulae (Text-fig. 32). The male from Church Point also has the frons slightly broader than in other males, with the interfrontalia a little broader than diameter of anterior ocellus; it also has the squamae broadly brown and the knob of halteres brown. One female from Yeppoon has a short $p$ seta on each fore tibia, the only specimen in about I6o specimens of the impar-group studied by me to be aberrant in this way. The females from Howard Springs have the disc of the scutellum partially to largely infuscated, the abdomen with only tergite $I+2$ yellow, knob of halteres very infuscated, and the basal $a v$ and $p v$ setulae on hind femur stronger and more numerous than usual; this latter character links the usual condition of these setulae in Australia and the Solomon Islands breviseta with the rather hypertrophied condition in New Guinea, New Britain and Bougainville females.

The New Guinea males have the pteropleural setulae golden or golden-tipped below, and the setulae around propleural and prostigmatal setae golden (Boroko) or black; palpi wholly yellow, 3rd antennal segment weakly to distinctly infuscated, $4^{\text {th }}$

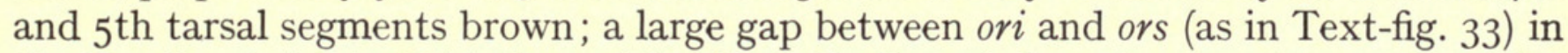
the Boroko o ; in the Biak Is. and Sepik 0 , the frons is broader, equal to 3 times diameter of anterior ocellus, interfrontalia equal to twice diameter of anterior ocellus, with 6-7 ori and no gap between ori and ors; tergites 4 and 5 black, tergite 3 with or without a dark hind-margin and median line; prosternum golden or dark setulose; hind tibia with I av seta. The females have the prosternal setulae mainly dark, palpi yellow or brown at base, and hind tibia with I av seta; tergite 3 yellow or largely infuscated. Both males and females may have the $p v$ and $a v$ setulae in the basal half of hind femur weak or well developed, half or more femoral depth.

The females from Keravat and Bougainville have the hind femoral setulae well developed as in the New Guinea females; prosternal setulae mainly dark, colour of palpi and antennae typical; abdomen wholly yellow (Keravat), only apical half of tergite 5 and hind-margin of tergite 4 black (Bougainville).

Variation in material from the Solomons is more marked. The males vary as follows: 3rd antennal segment wholly yellow to only faintly infuscated at tip. The gap between ori and ors not bridged (Russell), feebly bridged (Nggela) or entirely bridged (Lunga mouth); in the Lunga Bridge male the frons is slender, at narrowest point separated by only a little over diameter of anterior ocellus, but the interfrontalia is distinct throughout and the ori and ors are not connected. Facial ridges without hairs above the cluster at vibrissal angle, except in the Lunga Bridge male. Palpi dark with the apical half to quarter yellow, wholly yellow in the Lunga Bridge male. Pteropleural setulae pale below in the Lunga Bridge male. The last 3, sometimes 4, tarsal segments brown. Hind femur rather more hairy ventrally, except in the 
Lunga males. Hind tibia more frequently with a second $a v$ seta, often on both legs. Tergite 4 yellow except for hind-margin and a broad median triangle.

Solomon Islands females are rather uniform and differ less strikingly from the typical form. The Malaita female has the apical half of tergite 4 infuscated, and the last 3-4 tarsal segments dark. Lunga River and Vella Lavella females are typical except for the dark tarsal segments $2-5$ in the latter. The Tenaru female is typical except that anterior half of tergite 4 is yellow. The Rendova female is typical, but the posterior half of tergite 3 and all of tergites 4 and 5 except for the antero-lateral corners of tergite 4 are dark. The Kolombangara females have the tarsi brown, with only the metatarsi rather yellow, and the abdominal pattern more or less as in the Rendova female.

Affinities: This species is closely related to parimpar and parviseta, but is closest to impar which it replaces in the Australasian region. The differences between breviseta and impar, of which only the female is known, are slight but such differences are in my view sufficient to justify the description of breviseta as new, and are supported by the enormous gap separating Java and New Guinea and the complete absence of records of the species from the intervening territories. It is also certain that more significant differences will be found when the male of impar is discovered.

\section{Dichaetomyia parviseta sp. n.}

(Text-figs. 3I, 54, 57, 60)

Diagnosis: D. parviseta can be distinguished from the other species of the impargroup in the male sex by the yellow undusted mesonotum, entirely black abdomen, yellow pteroplural setulae, deep yellow wing-base and squamae, 2 av setae on hind tibia, and $2 d$ preapical setae on hind femur. The female is at present unknown.

o. Head: Frons slender, at narrowest point eyes separated by a little over, to almost twice, diameter of anterior ocellus. Eyes virtually bare, with only the usual microscopic pubescence; upper inner facets not much enlarged. Ocellar setae quite weak, half to three-quarters length of anterior prst $d c$. Vertical setae short, only slightly longer than the adjacent post-ocular setulae. Post-ocular setulae very short, with several scattered setulae below the upper row, most of which are black. Parafrontalia, parafacialia and face silvery white pruinose; genae black in groundcolour, brownish grey pruinose. Interfrontalia, viewed from below, with the visible parts grey pruinose. Parafrontalia slender throughout, at lunula equal to a little over diameter of anterior ocellus. Interfrontalia reduced, two small triangles visible before ocellar tubercle and at lunula, visible only as a seam on median third of frons. 3-4 pairs of inclinate ori on lower two-fifths of frons, with I-2 hair-like interstitials; I pair of fine hair-like ors just before ocellar tubercle (Textfig. 3I); in the San Cristobal of there are 2 pairs of hair-like setulae bridging the gap between ori and ors. Antennae and basal third of arista yellow; $3^{\text {rd segment white pruinose. } \quad 3^{\text {rd }} \text { antennal }}$ segment 3 times as long as broad, in frontal view reaching epistoma. Arista with long regular plumosity, the longest of which almost equals length of 3 rd antennal segment. Parafacialia slender, opposite insertion of arista equal to diameter of anterior ocellus. Parafacialia and genae bare. In lateral view, parafrontalia and parafacialia largely invisible; vibrissal angle projecting slightly beyond profrons. Genae slender; the depth below lowest eye-margin almost equal to width of 3 rd antennal segment. Peristomal setae rather dense, especially behind. Beard black, with numerous golden setae. Facial ridges with short hairs ascending to midway level of 3 rd antennal segment. Mentum of proboscis brown. Palpi brown, the tips yellow; compressed, quite slender, weakly clavate towards tips. Thorax: Thorax and scutellum entirely yellow in 
ground-colour. Viewed from above and behind, mesonotum undusted, without traces of any white dust at neck or along prst $d c$ rows. Scutellum undusted, pleura virtually undusted. Anterior spiracle pale yellow. Mesonotum with the ground-setulae rather short and sparse, except those between the $d c$, black unless otherwise stated; those on pleura golden unless otherwise stated. $A c r o+\mathrm{I}$, the single $(p r s c)$ pair well developed, placed behind the transverse level of prsc $d c$ and slightly closer to each other than to the $d c .2 h$, the outer one one and a half times length of the inner one. $2 p h$, the posterior one twice length of the anterior one. $2 i a .2 s a$, the posterior one weak. Post-alar callus with 2 setae, with setulae present on the ridge between inner seta and scutellum. Post-alar declivity with a few pale hairs. Supra-squamal ridge bare. Prosternum golden setulose. Propleural depression bare. I propleural and I prostigmatal seta, each with an auxiliary seta below; the former surrounded by few, the latter by numerous golden setulae. Ist $n p l$ longer and stronger than 2 nd; disc of notopleuron bare or with I-3 dark or golden setulae around the bases of both setae. Mesopleuron with 4 strong setae in caudal row, and a conspicuous black setula in upper anterior corner. Infra-alar bulla yellow, bare. Pteropleuron with the setulae on sub-alar ridge confined to anterior part, a few descending down to sternopleural and hypopleural margins, all of them golden, only a few of those on sub-alar ridge sometimes brown. Stpl I +2 , the lower one slightly shorter than the anterior one and only slightly closer to posterior one than to anterior one. Hypopleuron with the hairs on metepisternum golden. Metathoracic spiracle small, subtriangular, with a row of black setulae on lower margin. Scutellum with a very strong apical and sub-basal lateral pair of setae. Disc with rather short dense setulae, a few stronger ones apically and laterally. Legs: Yellow, tarsal segments $3-5$ brown. Tarsi unremarkable. Fore femur without av setae, with a complete row of $p v$ setae. Mid femur with a few fine $p v$ setae in basal third, none of which is as long as femoral depth, otherwise without $a v$ or $p v$ setae; I $a$ and $3-4 d$-p preapical setae. Mid tibia with $2 p$ setae. Hind femur with 3-4 longer $a v$ and $p v$ setulae in basal third, and with 3-4 preapical $a v$ setae; $a d$ row complete; $2 d$ and I $p d$ preapical setae. Hind tibia with I $a d$ and 2 weaker $a v$ setae; some of the $p d$ ground-setulae more erect in apical half; $a d$ and $d$ preapical setae subequal, and subequal to tibial depth. Wings: Yellowish tinged, intensely so at base. Epaulet and basicosta yellow. Subcostal sclerite bare. Costa setulose ventrally as far as the apex of vein 2, the spine inconspicuous. Stem-vein with a few golden hairs below. Small cross-vein placed basad of or below the point where vein I enters costa. Hind cross-vein oblique, weakly sinuate. Vein I bare. Vein 3 bare above; below with a few setulae on the node at base and just beyond. Vein 4 inclined weakly forward towards vein 3 in apical section. Squamae and margins deep yellow, fringes pale. Knob of halteres brown. Abdomen: Ground-colour entirely black. Sternite I yellow, sternites $2-5$ black. In posterior view, tergites hardly dulled by dust, subshining; finely shagreened and not glossy. Macrochaetae quite well developed, rather stronger and more erect than in breviseta: tergites 4 and 5 each with a marginal row, tergite 4 with $\mathrm{I}-2$ lateral discals and tergite 5 with a discal row. Sternite I golden setulose. Genitalia: Text-figs. 54, 57, 6o. Measurements: Length of body, $7 \cdot 0-8 \cdot 0 \mathrm{~mm}$. Length of wing, $6 \cdot 5-7 \cdot 5 \mathrm{~mm}$.

ㅇ. Unknown.

Holotype ô. Solomon Islands: Ugi, 6.v.I934 (R. A. Lever), BMNH.

Paratypes, 3 o. Solomon Islands: Ugi, $2 \hat{o}$, 6.v.I934 (R. A. Lever), BMNH; San Cristobal, Kira-Kira, 0-50 m., swept, I ô, Io.xi.rg64 (R. Straatman), Bishop.

Distribution and biology: Known only from the most eastern islands of the Solomons group, Ugi and San Cristobal. Life-history and immature stages unknown; one adult was swept, habits otherwise unknown.

Affinities: D. parviseta is more closely related to breviseta than to parimpar or impar, as the broader frons and more strongly developed abdominal macrochaetae indicate. The male $5^{\text {th }}$ sternite has however much shorter lobes than any of these species. The entirely dark abdomen, pale pleural setulae, and deep yellow wing-base 
and squamae give it a very characteristic appearance and separate it immediately from the other species. The unknown female may be expected to have these characters too. Certain characters that are constant in the small series available, such as colour of antennae and palpi, few $n p l$ setulae and $2 a v$ setae on hind tibia, may be found to vary when further material is studied.

Discussion: It seems to be more likely that this is an island species that has evolved in the eastern Solomon Islands from proto-breviseta-parimpar stock, than that it is a species of formerly wide distribution that has gradually been superseded and replaced by breviseta, penetrating from the west, and now restricted to what were previously the outer limits of its distribution.

\section{THE VICARIA-GROUP}

This group includes fourteen described Oriental and Australasian species in which there are 4 post $d c$ setae, fore tibia without a submedian $p$ seta, and scutellum without black or pale setulae on the lateral or ventral surfaces, at most with a few setulae descending just below the level of the strong setae.

The vicaria-group possesses the following additional characters:

Mentum of proboscis dusted. 2 prst dc setae. Prst acr setulae 7- to 9-serial. Pra welldeveloped but short, about half length of 2 nd $n p l$. Vallar ridge haired anteriorly or bare. Hypopleuron bare on beret, haired below spiracle and on metepisternum, rarely bare individually. Squamopleuron haired. Scutellum with up to ro setulae descending just below the level of the strong setae. Stem-vein usually bare above, sometimes with a few fine short pale hairs at base. Lower squama bare.

So far as I know there are fourteen described species and three subspecies in this group, most of which are Australasian. I have also seen a number of undescribed species from Melanesia and the Pacific. Apart from the eight Australian species discussed in this paper, the following species belong to this group:

D. prolixa (Walker) from Makasar, with its subspecies bioculata Emden (Thailand, Malaya) and pallidorsis Emden (Thailand, Ceylon). D. prolixa prolixa has a broad black vitta on the mesonotum from neck to scutellum, between the $d c$ setae, tergites 3 and 4 with broad black fasciae, tergite 5 with a pair of black lateral spots. D. prolixa bioculata has the mesonotum almost entirely dark, pteropleural and prosternal setulae dark, male hind femur with a few $p v$ setae confined to basal $\frac{2}{3}$. D. prolixa pallidorsis has the mesonotum immaculate, abdomen immaculate except for a pair of black lateral spots on tergite 5 , and hind femur with some $p v$ setae in basal half; it differs from australis sp. $\mathrm{n}$. by the black prosternal setulae among other characters.

The following Micronesian species, described and keyed by Snyder (I965: $296 \mathrm{ff}$.), belong to this group: mariana Snyder, yapensis Snyder, trukensis Snyder, and saperoi Bohart and Gressitt. To judge from the descriptions, they are all most closely allied to australis sp. n. and megophthalma Malloch.

D. fumicosta fumicosta Malloch and fumicosta savaii Malloch from Samoa both have the wings very conspicuously infuscated. Otherwise they are closely related to australis and megophthalma; see below under australis (p. 24I). 


\title{
Dichaetomyia terraereginae Malloch
}

\author{
(Text-figs. 4, 6, 62, 65, 68)
}

Dichaetomyia terraereginae Malloch, I925: 325. Holotype $₫$, QueEnsLAnd: Dawson River. In the School of Public Health and Tropical Medicine, Sydney. [Examined.]

Dichaetomyia terraereginae Malloch; Lee, Crust \& Sabrosky, I956 : 337.

Note on types: Malloch (l.c.) described the "type and allotype" as from the Dawson River, Queensland, I923 (Bancroft). Lee, Crust \& Sabrosky (1.c.) state that the holotype male is in the BM, but this BM male, labelled as type by Malloch, is from S. Queensland. The holotype, from Dawson River, is actually in the SPHTM, and is also labelled as type by Malloch. Evidently the error in Lee, Crust \& Sabrosky is due to Malloch's labelling two different males as type. I have studied the holotype (SPHTM), allotype (SPHTM) and 12 paratypes (8 in BM, 2 in SPHTM, 2 in USNM). One male paratype, from Loowanna, E. Dorrigo, 30.i.I923 (in SPHTM), is certainly not terraereginae and is probably vicaria (Walker). Otherwise all the type-material belongs to my concept of this species.

Diagnosis: $D$. terraereginae can be distinguished from all other species of the vicariagroup except for rufaeformis and megophthalma by the entirely black prosternal and pteropleural setulae, and by the absence of setulae on the ridge between inner postalar seta and scutellum (as in Text-fig. 2). In the male sex, terraereginae differs from both these species by the long preapical $a v$ and $p v$ setae on hind femur (Text-figs. 4 and 6), but the female cannot be distinguished from that of rufaeformis.

๙. Head: Eyes virtually bare, with only the usual microscopic pubescence. Ocellar setae quite strong, but not as long as anterior prst $d c$. Vertical setae short, only slightly longer than the adjacent post-ocular setulae. Post-ocular setulae very short, with several scattered setulae below the upper row, which are almost entirely black. Parafrontalia and parafacialia silvery white pruinose, face more thinly so; genae brownish grey pruinose. Interfrontalia, viewed from below, with the visible parts brownish grey pruinose. Parafrontalia slender, at lunula equal to diameter of anterior ocellus. Interfrontalia reduced, two small triangles visible before ocellar tubercle and at lunula, visible as a line or obsolete and not even visible as a seam on median third of frons. I pair of strong ori at lunula, with a weaker pair and 3-5 hair-like pairs above them, all on lower two-fifth to half of frons; I pair of tiny reclinate ors just before ocellar tubercle. Antennae and basal third of arista yellow, the first two segments sometimes dull yellow, 3rd segment largely darkened beyond arista, grey pruinose. 3rd segment three and a half times as long as broad, in frontal view almost reaching epistoma. Arista with long regular plumosity, the longest of which almost or quite equals length of 3 rd antennal segment. Parafacialia slender, opposite insertion of arista equal to slightly less than diameter of anterior ocellus. Parafacialia and genae bare. In lateral view, parafrontalia and parafacialia visible though slender, or only partially visible; vibrissal angle projecting slightly beyond profrons. Genae slender; the depth below lowest eye-margin equal to slightly less than width of 3 rd antennal segment. Peristomal setae rather dense, especially behind. Facial ridges without short hairs above the usual cluster at vibrissal angle, or a few ascending to level of lower third of 3 rd antennal segment. Mentum of proboscis black. Palpi wholly brown, to yellow in apical half and brown in basal half, to wholly dull yellow; compressed, slender, weakly clavate towards tips. Thorax: Thorax and scutellum entirely yellow in ground-colour. Viewed from above and behind, mesonotum uniformly whitish grey dusted, more densely so before suture where a pair of narrow undusted paramedian vittae is indicated mesad of the $d c$; sometime also with a pair of undusted patches indicated 
before suture between $p h$ and $d c$, and behind suture between $i a$ and $d c$. Scutellum thinly white dusted, more conspicuously so in basal lateral corners; pleura virtually undusted. Spiracles pale yellow. Mesonotum with the ground-setulae quite numerous and erect, especially between the $d c$, all thoracic ground-setulae black unless otherwise stated. $A c r o+\mathrm{I}$, the single (prsc) pair quite strong, closer to each other than to the $d c$. All $d c$ setae strong. $2 h$, the outer one one and a half times length of the inner one. $2 p h$, the posterior one almost twice length of the anterior one. $2 i a$, the anterior one fine. $2 s a$, the posterior one weak. Post-alar callus with 2 setae. Post-alar declivity with a few scattered pale or dark hairs. Supra-squamal ridge bare. Propleural depression bare. I propleural and I prostigmatal seta, the former with an auxiliary seta; the former surrounded by few, the latter by numerous setulae. Ist $n p l$ longer and stronger than 2nd; disc of notopleuron with several setulae around the bases of both setae though fewer around the anterior one. Mesopleuron with 4 strong setae in caudal row, and a conspicuous black setula in upper anterior corner. Infra-alar bulla yellow, bare. Pteropleuron with the setulae on subalar ridge confined to anterior part, descending down to sternopleural and hypopleural margins. $S t p l$ I +2 , the lower one weaker than anterior one and much closer to posterior one than to anterior one. Hypopleuron with the hairs on metepisternum sometimes absent. Metathoracic spiracle quite large, subtriangular, with a row of black setulae on lower margin. Scutellum with very strong apical and sub-basal lateral setae. Disc with rather fine setulae, a few stronger ones apically and laterally. Legs: Yellow; tarsal segments 4 and 5 brown, often also segment 3 , sometimes only segment 5. Tarsi unremarkable. Fore femur without av setae, with a complete row of $p v$ setae. Mid femur without setae except for I $a$ and $3 d-p$ preapical setae, but the $a v$ and $p v$ ground-setulae rather denser in basal half. Mid tibia with $2 p$ setae. Hind femur with the $a d$ row complete; I $d$ and I $p d$ preapical setae. Hind tibia with I strong $a d$ and (o-) I (-2) fine $a v$ setae slightly apicad of it; some of the $p d$ ground-setulae more erect in apical half; $d$ preapical seta subequal to tibial depth, slightly shorter than the ad. Wings: Rather yellowish tinged, especially at base, sometimes quite intensely so; the veins pale. Epaulet and basicosta yellow. Subcostal sclerite bare. Costa setulose ventrally as far as the apex of vein 2, the spine inconspicuous. Stem-vein bare above, with a few pale or dark hairs below. Small cross-vein placed below or slightly beyond the point where vein I enters costa. Hind cross-vein oblique, rather sinuate. Vein I bare. Vein 3 usually with a few setulae on the node at base above; below with setulae on the node at base extending about halfway to small cross-vein. Vein 4 inclined weakly forward towards vein 3 in apical section. Squamae rather dirty yellow, margins concolourous. Knob of halteres dull yellow. Abdomen: Ground-colour yellow, tergites 4 and 5 usually darkened. Sternites yellow. In posterior view, tergites rather dulled by dust. Macrochaetae quite erect: tergite 3 with some lateral marginals, tergite 4 with some lateral discals and a marginal row, tergite 5 with a discal row, interrupted medially, and a marginal row. Genitalia: Text-figs. 62, 65, 68. Measurements: Length of body, 6.0-7.0 mm. Length of wing, 5.5-6.5 mm.

․ Differs from the male as follows. Head: Eyes broadly separated; frons at middle less than an eye-width, broadening gradually to lunula. Upper inner eye-facets not enlarged. Ocellar setae strong, almost equal to and prst $d c$ seta, directed forwards and slightly outwards. The incurved $v t i$ not much longer than the outcurved vte; pvt outcurved, over half length of vte. Parafrontalia silvery white pruinose on lower quarter to third, otherwise grey pruinose, usually subshining black alongside ocellar tubercle. Interfrontalia black in ground-colour; viewed from below, brownish grey pruinose with the frontal triangle contrasting brown; frontal triangle otherwise visible as an ill-defined black streak extending three-quarters or almost the entire distance from anterior ocellus to lunula. Parafrontalia slender, broadening gradually towards lunula; at middle equal to twice diameter of anterior ocellus, at lunula broader than width of 3 rd antennal segment. Interfrontalia with the margins convex, broadest at middle of frons, at lunula broader than a parafrontale, bare. 3-4 pairs of inclinate ori on lower two-thirds of frons, only the lowest pair really strong, with a few interstitials; 2 pairs of reclinate ors, the upper pair stronger than lower and placed closer to it than to vti; parafrontalia otherwise with short proclinate setulae on whole length. Parafacialia slightly broader, opposite insertion of arista slightly broader than diameter of anterior ocellus. In lateral view, parafrontalia and parafacialia visible but slender. Facial ridges with the hairs ascending to midway level of 3 rd antennal segment. Palpi brown. Thorax: 
Viewed from above and behind, mesonotum and scutellum undusted except on humeri and a small median patch of white dust at neck. Prsc acr placed on, behind or in front of the transverse level of prsc dc. Auxiliary prostigmatal seta well developed, sometimes weak. Notopleuron with very few setulae, often bare around ist seta. Legs: Sometimes all tarsi yellow except for the brownish 5 th segment. Mid femur without denser erect $a v$ and $p v$ ground-setulae. Hind femur with 4 preapical $a v$ setae, none equal to femoral depth. Abdomen: In posterior view virtually undusted. Macrochaetae reduced: tergite 4 with $\mathrm{I}-2$ lateral discals and a few lateral marginals, tergite 5 with a few lateral discals and a weak marginal row. Ovipositor: Indistinguishable from that of rufaeformis. Measurements: Length of body, $6 \cdot 0-6.5 \mathrm{~mm}$. Length of wing, $5.5-$ $6 \cdot 0 \mathrm{~mm}$.

Material examined. Holotype $\widehat{0}$. Queensland: Dawson River, I923 (Bancroft), SPHTM.

QueEnsland: Dawson River, I923 (Bancroft), $q$ allotype, SPHTM; 8 ô paratypes

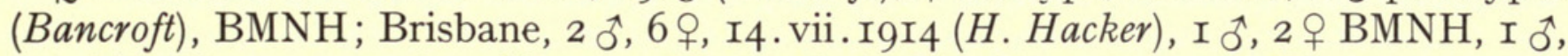
4 ㅇ Qld. Mus.; I đૈ, I ㅇ, 7.iii.I925 (H. Hacker), Qld. Mus.; Dawson River, I ㅇ, I923 (Bancroft), SPHTM; Tinaroo Falls Dam, open savannah, I ô, 5 ㅇ, 27.iv. I967 (D.H.

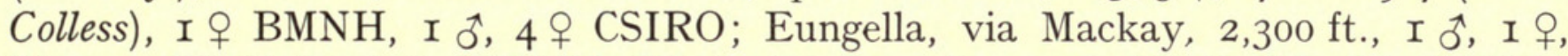
iii.I929 (F. H. Taylor), SPHTM; Nindooinbah, I ô, v.I954 (K. R. Norris), CSIRO; II miles N. of Yeppoon, I ô, Io.v. I955 (K. R. Norris), CSIRO; 63 miles N. of Marlborough, I ô, 9.v.I955 (K.R. Norris), BMNH; Mt. Tambourine, I ठ, I क, 9.iv. I955 (K. R. Norris), CSIRO; Fassifern Valley, I ô, 23.ii.I954 (K. R. Nurris), CSIRO; Numinbah Valley, I ô, 3 ㅇ, 5.xi. 954 (R. Meyers), I + BMNH, I ㅅ․ 2 우 CSIRO; Highvale, I4 miles N.W. of Brisbane, I ô, 3.i.Ig6o (R. Straatman), CSIRO; Clayton Gully, $2 \frac{1}{2}$ miles E. of Cunningham's Gap, I ô, I ㅇ, I.vi. Ig66 (Z. Liepa), ô BMNH, ㅇ CSIRO; Beerburrum Creek, Beerburrum, I ô, 23.v.Ig66 (Z. Liepa), CSIRO; Mitchell Gully, 2 miles E. of Cunningham's Gap, I ô, 5 우, 2.vi. Ig66 (Z. Liepa), 2 우 BMNH, I ô, 3 ㅇ CSIRO.

New South Wales: Coramba-Dorrigo Road, I,00o ft., I ô paratype, 3r.i.I923 (Health Dept.), USNM; Lisarow, on human faeces, 2 ô paratypes, I.v.I9I5, USNM and SPHTM; Cessnock, I ô, 2I.iv.I955 (I. G. Filmer), Qld. Mus.; Waterfall, by sweeping, I ô, 23.xi.I959 (M. Nikitin), BMNH; Ryde Road [near Sydney], on Aralia flowers, I ô, 6. vi. I963 (J. H. Ardley), SPHTM; Sydney University, W/A Trapping, 2 ơ, I2-I5.iv. I963 ( $J$. H. Ardley), SPHTM; Maroubra, Sydney, I ô, 24.v.I925 (Health Dept.), SPHTM; Allowrie, Killara, I ô, I5.iii.I922, SPHTM; Glenbrook, I ô, 5.v.I93I (F. Gay), CSIRO; Gordon, I ô, 7.ii.I934 (D.F. Waterhouse), BMNH; Colo Vale Bottom, I7I2-30, to man, I ô, 24.iv.r956 (A. Dyce), SPHTM; Springwood, Blue Mountains, 2 ô, Io.i.I956, and I +, 30.i.I956 (D. K. McAlpine), Aust. Mus.; N. Bondi, I ô, I q, 22.iv. Ig62, I +, 4.vi.I962, and I 9, 5.v.I962 (K. Kota), Aust. Mus.; Whian Whian State Forest, near Lismore, m.v. lamp, I đૈ, 25.ii. I965 (McAlpine and Lossin), Aust. Mus.; 30 miles S. of Singleton, Putty Road, I ô, 3 ㅇ, 6.ii. I968 (D. H. Colless), I ㅇ BMNH, I ô, 2 ㅇ CSIRO; Scotts Head, near Warrell Creek, I ô, I3.ii.rg68 (D. H. Colless), CSIRO; Upper Allyn River, I ô, I4.ii. I968 (D. H. Colless), BMNH.

Distribution and biology: Australia: Queensland and New South Wales. A common species. 
This species is found quite commonly up to $330 \mathrm{~m}$. in mainly dry habitats: open dairy country, open savannah, and savannah woodlands. It is found less commonly in wet eucalyptus forest, residual rain forest, and subtropical rain forest. It has been collected on Aralia flowers and by sweeping, in carrion-baited blowfly traps and in Western Australian fly traps. It has been caught on human faeces and on man.

Life-history and immature stages unknown.

Variation: Some specimens lack the hairs on metepisternum, and a few possess a single setula on the vallar ridge.

Affinities: D. terraereginae is unique among males of the vicaria-group in possessing long preapical $a v$ and $p v$ setae on hind femur. Several species have $p v$ setae on hind femur, but these are always arranged in a complete or partially complete row, before the apical third, and are never as long and strong as they are in this species.

\title{
Dichaetomyia rufaeformis sp. $\mathrm{n}$.
}

\author{
(Text-figs. 2, 5, 7, 63, 66, 69)
}

Diagnosis: D. rufaeformis can be distinguished from all other species of the vicariagroup except for terraereginae and megophthalma by the entirely black prosternal and pteropleural setulae and by the absence of setulae on the ridge between inner post-alar seta and scutellum (Text-fig. 2). In the male sex, rufaeformis differs from both species by the lack of strong $p v$ setae on hind femur except for a short submedian one (Text-fig. 5), but the female cannot be distinguished from that of terraereginae.

o. Head: Eyes virtually bare, with only the usual microscopic pubescence. Ocellar setae quite strong, but not as long as anterior prst dc. Vertical setae short, only slightly longer than the adjacent post-ocular setulae. Post-ocular setulae very short, with several scattered setulae below the upper row, which are almost entirely black. Parafrontalia and parafacialia silvery white pruinose, face more thinly so; genae greyish pruinose. Interfrontalia viewed from below, with the visible parts brownish grey pruinose. Parafrontalia slender, at lunula equal to diameter of anterior ocellus. Interfrontalia reduced, two small triangles visible before ocellar tubercle and at lunula, obsolete on median third of frons and not even visible as a seam. 3 pairs of inclinate ori, with 3-4 fine interstitials, all on lower two-fifths of frons; I pair of tiny reclinate ors just before ocellar tubercle. Antennae and basal third of arista yellow; 3rd segment weakly to conspicuously infuscated beyond arista or just before tip, whitish pruinose. 3rd segment three and a half times as long as broad, in frontal view almost reaching epistoma. Arista with long regular plumosity, the longest of which exceeds length of 3 rd antennal segment. Parafacialia slender, opposite insertion of arista equal to slightly less than diameter of anterior ocellus. Parafacialia and genae bare. In lateral view, parafrontalia and parafacialia visible though slender; vibrissal angle projecting slightly beyond profrons. Genae slender; the depth below lowest eye-margin equal to slightly less than width of 3 rd antennal segment. Peristomal setae rather dense, especially behind. Facial ridges with short hairs ascending to level of lower third of 3 rd antennal segment. Mentum of proboscis black. Palpi usually wholly brown, sometimes yellow at apex and grading to brown at base; compressed, slender, weakly clavate towards tips. Thorax: Thorax and scutellum entirely yellow in ground-colour. Viewed from above and behind, mesonotum uniformly whitish grey dusted, more densely so before suture where a pair of narrow undusted paramedian vittae is usually indicated mesad of the $d c$; usually also an undusted patch indicated before suture between $p h$ and $d c$, and, after suture, between $i a$ and $d c$. Scutellum quite densely dusted, thinning out towards tip. Pleura virtually undusted. Spiracles pale yellow. Mesonotum with the ground-setulae quite numerous and erect, especially between the $d c$, all thoracic ground-setulae black unless otherwise stated. $A c r o+\mathrm{I}$, the single $(p r s c)$ pair quite strong and 
closer to each other than to the $d c$. All $d c$ setae strong. $2 h$, the outer one one and a half times length of the inner one. $2 \mathrm{ph}$, the posterior one almost twice length of the anterior one. $2 \mathrm{ia}$, the anterior one fine. $2 \mathrm{sa}$, the posterior one weak. Post-alar callus with 2 setae. Post-alar declivity with a few scattered pale or dark hairs. Supra-squamal ridge bare. Propleural depression bare. I propleural and I prostigmatal seta, each with an auxiliary seta below; the former surrounded by few, the latter by numerous, setulae. Ist $n p l$ longer and stronger than 2nd; disc of notopleuron with several setulae around the bases of both setae. Mesopleuron with 4 strong setae in caudal row, and a conspicuous black setula in upper anterior corner. Infra-alar bulla yellow, bare. Pteropleuron with the setulae on sub-alar ridge confined to anterior part, descending down to sternopleural and hypopleural margins. Stpl I +2 , the lower one weaker than anterior one and much closer to posterior one than to anterior one. Metathoracic spiracle quite large, subtriangular, with a row of black setulae on lower margin. Scutellum with a very strong apical and sub-basal lateral pair of setae. Disc with rather fine setulae, a few stronger ones apically and laterally. Legs: Yellow, tarsal segments 3 to 5 brown. Tarsi unremarkable. Fore femur without $a v$ setae, with a complete row of $p v$ setae. Mid femur without setae except for I $a$ and $3 d-p$ preapical setae, but the $a v$ and $p v$ ground-setulae rather denser in basal half. Mid tibia with $2 p$ setae. Hind femur with the $a d$ row complete; I $d$ and I $p d$ preapical setae. Hind tibia with I strong $a d$ seta, and I fine $a v$ slightly apicad of it; some of the $p d$ ground-setulae more erect in apical half; $d$ preapical seta subequal to tibial depth, slightly shorter than the $a d$. Wings: Rather yellowish tinged, especially at base; the veins pale. Epaulet and basicosta yellow. Subcostal sclerite bare. Costa setulose ventrally as far as the apex of vein 2, the spine inconspicuous. Stem-vein bare above, with several short dark hairs below. Small cross-vein placed slightly basad to apicad of the point where vein I enters costa. Hind cross-vein oblique, rather sinuate. Vein I bare. Vein 3 often with a few setulae on the node at base above; below with setulae on the node at base extending about halfway to small cross-vein. Vein 4 inclined weakly forward towards vein 3 in apical section. Squamae rather dirty yellow, margins concolourous. Knob of halteres dull yellow. Abdomen: Ground-colour mainly yellow, but rather variable in extent of infuscation: tergite $I+2$, most of tergite 3 and part or apical half of tergite 5 yellow; hind-margin of tergite 3 , tergite 4 and anterior part or half of tergite 5 dark; but sometimes much lighter, with dark areas very reduced. Sternites yellow to dark. In posterior view, tergites uniformly dusted grey to brownish grey, without an undusted median vitta or undusted hindmargins. Macrochaetae quite erect: tergite 3 with some lateral marginals, tergite 4 with some lateral discals and a marginal row, tergite 5 with a discal row that is interrupted medially and a marginal row. Genitalia: Text-figs. 63, 66, 69. Measurements: Length of body, 5.5-6.5 mm. Length of wing, $5 \cdot 0-6 \cdot 0 \mathrm{~mm}$.

․ Differs from the male as follows. Head: Eyes broadly separated; frons at middle less than an eye-width, broadening gradually to lunula. Upper inner eye-facets not enlarged. Ocellar setae strong, almost equal to and prst $d c$ seta, directed forwards and slightly outwards. The incurved $v t i$ not much longer than the outcurved $v t e$; pvt outcurved, weak, usually over half length of vte but sometimes shorter. Parafrontalia silvery white pruinose on lower quarter only, otherwise grey pruinose, subshining black alongside ocellar tubercle. Interfrontalia black in groundcolour; viewed from below, greyish pruinose with the frontal triangle not usually contrasting brownish; frontal triangle otherwise visible as an ill-defined black streak extending threequarters distance from anterior ocellus to lunula. Parafrontalia slender, broadening gradually towards lunula; at middle equal to twice diameter of anterior ocellus, at lunula broader than width of 3 rd antennal segment. Interfrontalia with the margins convex, broadest at middle of frons, at lunula subequal to or broader than a parafrontale, bare. 3-4 pairs of inclinate ori on lower two-thirds of frons, only the lowest pair really strong, with a few interstitials; 2 pairs of reclinate ors, the upper pair stronger than lower and placed closer to it than to vti; parafrontalia otherwise with short proclinate setulae on whole length. 3rd antennal segment more strongly infuscated, dark beyond insertion of arista. Parafacialia slightly broader, opposite insertion of arista slightly broader than diameter of anterior ocellus. Facial ridges with the hairs ascending to midway level of 3 rd antennal segment. Palpi brown, yellow at apex. Thorax: Viewed from above and behind, mesonotum and scutellum undusted except on humeri and a small median 
patch of white dust at neck. Prsc acr placed on or behind the transverse level of prsc dc. Auxiliary prostigmatal present, sometimes absent. Notopleuron with fewer setulae, often bare around Ist seta. Legs: Sometimes only $4^{\text {th }}$ and $5^{\text {th }}$ tarsal segments brown. Mid femur without denser erect $a v$ and $p v$ ground-setulae. Hind femur with 3-4 preapical $a v$ setae, only I equal to femoral depth. Abdomen: In posterior view virtually undusted. Macrochaetae reduced: tergite 4 with I-2 lateral discals and a few lateral marginals, tergite 5 with a few lateral discals and a weak marginal row. Ovipositor: Indistinguishable from that of terraereginae. Measurements: Length of body, 5.5-6.5 mm. Length of wing, 5.o-6.o $\mathrm{mm}$.

Holotype $\widehat{0}$. QueEnsland: I mile E. of Kuranda, 4.v.I955 (K. R. Norris), CSIRO.

Paratypes, 25 ๙ิ, 20 우. QueEnsland: Byfield, 2 ๙ै, I 우, ro.v. I955 (K. R. Norris),

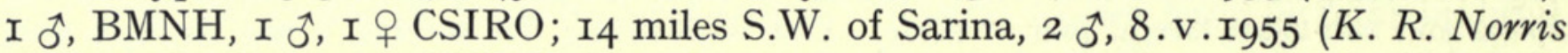
ㅇ I. F. B. Common), CSIRO; Iron Range, 2 ô, 5 q, II and I3.iv. I964 (I. F. B. Common 의 M. S. Upton), I §ิ, 2 ㅇ BMNH, I ô, 3 우 CSIRO; 4 miles E. of El Arish, I $\hat{\jmath}$, I + , I.v. I958 (T. G. Campbell), CSIRO; Forest Road, near Ingham, I ô, 20.iii.I96I (R. Straatman), CSIRO; 4 miles W. of Kuranda, I ㅇ, 4.v.I955 (K. $R$. Norris), CSIRO; Bamaga, Cape York, I , 4.iv. I964 (I. F. B. Common \& M. S. Upton), CSIRO; Cairns, ex corn, I ơ (A. P. Dodd), Bishop; Kuranda, 200 m., I 우, I4.iii.r956 (J. L. Gressitt), Bishop; 3 miles W. of Kuranda, Mareeba Road, I ô, 3.v. Ig67 (D. H. Colless), CSIRO; Earl Hill, N. of Cairns, 2 ơ, I ㅇ, 8.v. I967 (D. H. Colless), CSIRO; Bramston Beach, near Innisfail, rainforest fringe, I ô, 30.iv. I967 (D. H. Colless), BMNH; Bramston Beach, near Innisfail, open savannah, I ô, I o, 30.iv. Ig67 (D. H. Colless), CSIRO; Claudie River near Mt. Lamond, I $\boldsymbol{\sigma}^{\text {, I } ~}$, I.vi.rg66, and I +, 29.v.rg66 (D. K. McAlpine), Aust. Mus.; Kuranda, I ô, 28. xii.I958, and I $\widehat{o}, 2 \mathrm{I} . \mathrm{v} \cdot \operatorname{I958}$ (D. K. McAlpine), Aust. Mus.; Mulgrave River, 4 miles W. of Gordonvale, I ô, 29.xii. I958 (D. K. McAlpine), Aust. Mus.; Mt. Spec, 2 ô, I ㅇ, r.iv.rg65 (D. E. Havenstein).

Northern Territory: Lee Point, Darwin, 5 ô, 5 ㅇ, 7.iii.rg67 (M. S. Upton), I ô, I ㅇ BMNH, 4 ô, 4 우 CSIRO.

Not paratypes. Queensland: Cape York, Bamaga, I ô, I5.ii.rg62 (D. B. Copeman), CSIRO; Kuranda, 200 m., I ô, 4 ㅇ, I4.iii.I956 (J. L. Gressitt), I 우 BMNH, I ô, 3 ㅇ Bishop; Kuranda, I ㅇ, I3.iii. I956 (J. L. Gressitt), Bishop; Kuranda, 350 m., I ㅇ, 7.v. Ig6r (L. \& M. Gressitt), Bishop; Kuranda, $35^{\circ}$ m., rain forest, I $\sigma^{\star}$, 6.v.rg6r (L. \& M. Gressitt), Bishop; Stanthorpe, I ô, 3I.v.r927 (H. Jarvis), Qld. Dept. Pr. Ind.; Springsure, 2 ș, I +, 2.iii.I965 (D. E. Havenstein), CSIRO.

Not paratypes. WEST IRIAN: Eramboe, $80 \mathrm{~km}$. ex Merauke, 3 $\widehat{\jmath}, 2$ 우, 5.ii. Ig6o

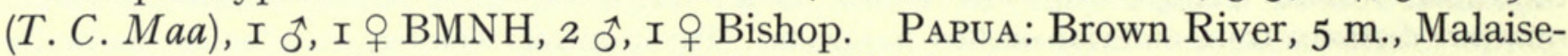
trap, I ô, 23.x. I96o (J. L. Gressitt), Bishop; W. District, Oriomo Govt. Sta., Malaisetrap, I ㅇ, 26-28.x. I960 (J. L. Gressitt), Bishop.

Distribution and biology: Australia: Northern Territory and Queensland. New Guinea (West Irian and Papua). A common species.

This species is found quite commonly up to $350 \mathrm{~m}$. in rain forest and open country: tropical rain forest, residual rain forest in dairy land and cane areas, open savannah and farming country. It has been trapped in carrion-baited blowfly traps, and collected on corn. 
In New Guinea it has been collected in Malaise-traps.

Life-history and immature stages unknown.

Variation: A very consistent species in colour and structure. The minor variations are noted in the description.

Affinities: In Australia, this species is very closely related to terraereginae, and females of the two cannot be separated. At first, however, I considered rufaeformis to be a form of vicaria, possessing the hind femoral setae of vicaria but the dark thoracic setulae of terraereginae. Further study and dissection of the genitalia showed quite clearly that a distinct species is involved close to terraereginae (Text-figs. 62-63, $65-66,68-69$, compare $72,75,78)$. D. rufaeformis can be separated from vicaria by the characters given in the key above, and these structural and chromatic characters are remarkably constant.

It is also very closely related to yapensis Snyder, from Yap Island in the Caroline group, but this species differs from rufaeformis by the different mesonotal pattern (dusted only presuturally, along the $d c$ rows and on a median patch), only I ia seta, mid and hind femora largely darkened, and vein 3 bare above.

\section{Females of Dichaetomyia terraereginae Malloch and rufaeformis sp. n.}

Females of these species cannot be distinguished. According to the males studied, the species are allopatric so that females collected at the same localities as males are listed under each species above. Females collected without associated males could not be named and are listed below.

Characters such as the position of prsc acr setae and absence of auxiliary prostigmatal seta, and characters on the frons, are not apparently of any value in this sex and could not be used. Repeated study of external colour and structure, and of the structure of the ovipositor, failed to reveal any differences.

Several females in the series below lack the white spot of dust on the mesonotum at neck, and also lack the fine hairs on metepisternum.

Queensland: Bell Bird L'out, Lamington Nat. Park, I +, 30.v. Ig66 (Z. Liepa), CSIRO; Woombye, near Nambour, I 9 , II-I6.x.I965 (D. H. Colless), CSIRO; Mount Spec, 2 ㅇ, 22.iv.I955 (K. R. Norris), BMNH and CSIRO; Mingela, 2 우, 2I.iv. I955 (K. R. Norris), BMNH and CSIRO; 63 miles N. of Marlborough, I + , 9.v.I955 (K. R. Norris), CSIRO; Currumbin, 2 ㅇ, 9.iv.I954 (K. R. Norris), CSIRO; I2 miles S. of Ingham, 2 +, 24.iv. I955 (K.R. Norris), CSIRO; Io miles S. of Daintree, I + , 29.iv.I955 (K.R. Norris), CSIRO; I2 miles S. of Ravenshoe, I ㅇ, 4.v.I955 (K. R. Norris), CSIRO; Kalbar, I ㅇ, 5.v.I954 (K. R. Norris), CSIRO; Eungella, $2,400 \mathrm{ft}$., I + , 7.v.I955 (K.R. Norris), CSIRO; 5 miles W. of Tully, I + , 23 .iv. I955 (K. R. Norris), CSIRO; Noosa Heads, I 으. 2I.ix.I963 (D. E. Havenstein), CSIRO; 50 miles W. of Miles, I + , Ir.i.I963 (D. E. Havenstein), CSIRO; Lamington National Park, I ㅇ, 20.v.Ig64 (R. A. McLachlan), Bishop; Mt. Glorious, I ㅇ, I3.ii. I96I (L. \& M. Gressitt), Bishop; Cape York Peninsula, Rocky R., N.E. of Coen, 500 m., 2 ㅇ, I2.v.I96I (L. \& M. Gressitt), Bishop; Upper Mulgrave River, Io m. Goldsborough Road, 3 ㅇ, 9.v. I967 (D. H. Colless), I BMNH, 2 CSIRO; 5 m. Tinaroo Falls-Danbulla 
Road, at light, I ㅇ, 26.iv. I967 (D. H. Colless), CSIRO; Wongabel State Forest, I ㅇ, 7.v.I967 (D. H. Colless), CSIRO; Gillies Highway, 2 m. W. of Little Mulgrave, I + I8.iv. Ig67 (D. H. Colless), CSIRO; 5-8 m. Mt. Lewis Road off Mossman-Mt. Mulloy Road, I + , 22.iv. I967 (D. H. Colless), CSIRO; Beaudesert, I + , 4.iii.I956, CSIRO; Claudie River near Mt. Lamond, I , 5 vi.rg66 (D. K. McAlpine), Aust. Mus.

New South Wales: Grafton, I ㅇ, I926 (W. W. Froggatt), CSIRO; 4 miles S. of Coolongalook, near Nabiac, I ㅇ, 2I.v.Ig66 (Z. Liepa), CSIRO; Manly Reservoir, Sydney, I ㅇ, 3.iv.I96I, and 2 +, 2 r.vii.rg63 (D. H. Colless), I BMNH, 2 CSIRO; North Coast Walloroo State Forest, I +, Io.x.I962 (D. H. Colless), BMNH; North Coast, Wootton, I 우 Io.x.I962 (D. H. Colless), BMNH; Io miles S. of Bateman's Bay, I + , 3.ix.I948 (E. F. Riek); CSIRO; Hawkesbury River, round human faeces, I +, 6.iv. I9ro (J. B. Cleland), BMNH; Sydney, I ㅇ, 6.xi.r92I, and I ㅇ, 23.x. I922 (Health Dept.), SPHTM; Sydney, I +, 5.xi.I926 (Ferguson), SPHTM; Hornsby, light trap, I + , Io.iv. I956 (D. J. Lee), SPHTM; Galston Gorge, W/A Trapping, I + , I2-I5. viii. I963 (J. H. Ardley), SPHTM; Kuringai Chase, 2 ㅇ, 23-26.ix.I963 (J.H. Ardley), SPHTM; Kuringai Chase, W/A Trapping, 3 ㅇ, 3-6.vi and I5-I8.vii. I963 (J. H. Ardley), SPHTM; Church Point, I + 9. 9.v.I959 (I. F. B. Common), CSIRO; Katoomba, I +, 8.i.I959 (G. H. Hardy), Aust. Mus.; National Park, I +, 6. viii. I955 (D. K. McAlpine), Aust. Mus.; Huonbrook near Mullumbimby, I +, 2.iii.1965 (McAlpine \& Lossin), Aust. Mus.; Goulburn River, near Baerami, I o, 29. viii. I956 (D. K. McAlpine), Aust. Mus.; Wollombi, near Cessnock, I ㅇ, 27.viii.r956 (D. K. McAlpine), Aust. Mus.; Ballengarra State Forest, 2 ㅇ, r3.ii.rg68 (D. H. Colless), CSIRO.

Australian Capital Territory: Black Mountain, light trap, I 9 , I4.iv. I956 (I. F. B. Common), CSIRO.

\section{Dichaetomyia megophthalma Malloch}

Dichaetomyia megophthalma Malloch, I925:325. Holotype đ. QueEnsLand: Cairns. In the United States National Museum, Washington. [Not examined.]

Dichaetomyia megophthalma Malloch; Lee, Crust \& Sabrosky, r956 : 324.

Diagnosis: D. megophthalma can be distinguished from all other species of the vicaria-group except for terraereginae and rufaeformis by the entirely black pteropleural setulae and the almost entirely black prosternal setulae, and by the absence of setulae on the ridge between inner postalar seta and scutellum (as in Text-fig. 2). In the male sex, megophthalma differs from both these species by the pale setulae on hypopleuron and sternite I, and by the strong median $p v$ setae on hind femur. Female unknown.

Malloch's original description of this species is as follows:

"Male.-Head fuscous, face paler, antennae yellow, third segment brownish apically, palpi fuscous. Thorax yellow, the grey pruinescence when viewed from behind forming a broad vitta anteriorly which is separated from the outer one on each side by a narrow line mesad of the dorsocentrals. Abdomen yellow. Apices of tarsi very slightly darkened. Wings, calyptrae, and halteres yellow. Fine thoracic hairs yellow. 
" Frons reduced to a mere line; facets of eyes suddenly enlarged at middle, those of upper half in large part individually as large as anterior ocellus and distinctly wider than frons at middle. Dorso-centrals $2+4$, all long; anterior intra-alar short. Hind femur with two or three preapical anteroventral bristles, and a series of fine bristles on basal half or more of posteroventral surface some of which are at least as long as diameter of femur; tibiae normal. Fourth vein curved.

" Length, $5.5 \mathrm{~mm}$.

“ Type, Cairns, North Queensland (J. F. Illingworth).

This species is known only from the holotype in the USNM, which I have been unable to study. Mr. G. C. Steyskal however has studied it on my behalf, and was kind enough to locate the species in my draft key to the vicaria-group and to supply some additional notes. I am most grateful to him for the care taken in ensuring that accurate data on this species are published.

Distribution and biology: Known only from North Queensland (Cairns). Biology, life-history and immature stages unknown.

Affinities: This species is most closely related to the Micronesian species mariana Snyder, yapensis Snyder, trukensis Snyder and saperoi Bohart and Gressitt, all of which possess some $p v$ setae in the basal half of hind femur in the male sex, and to the Samoan fumicosta fumicosta Malloch and fumicosta savaii Malloch. The data in my key above and Malloch's original description should be adequate for the recognition of megophthalma.

\title{
Dichaetomyia australis sp. $\mathrm{n}$.
}

\author{
(Text-figs. 8, I0, I2, 7I, 74, 77)
}

Diagnosis: D. australis can be distinguished in the male sex from other Australian species of the vicaria-group with black and yellow pteropleural setulae by the enlarged upper inner eye-facets and by the long $p v$ setae in basal half of hind femur (Textfig. 8). The female can be distinguished from all other Australian species of the vicaria-group by the $p v$ setae on hind femur (Text-fig. I2).

o. Head: Eyes virtually bare, with only the usual microscopic pubescence. Ocellar setae quite strong, but not as long as anterior prst $d c$. Vertical setae short, only slightly longer than the adjacent post-ocular setulae. Post-ocular setulae very short, with a few scattered setulae below the upper row that include some pale ones. Parafrontalia and parafacialia silvery white pruinose, face more thinly so; genae reddish in ground-colour, brownish grey pruinose. Interfrontalia, viewed from below, with the visible parts grey pruinose. Parafrontalia very slender, at lunula equal to diameter of anterior ocellus. Interfrontalia reduced, two small triangles visible before ocellar tubercle and at lunula, obsolete on median half of frons and not even visible as a seam. I pair of inclinate ori at lunula, with 3-4 hair-like pairs above, all on lower two-fifths of frons; o-I pair of tiny reclinate ors just before ocellar tubercle. Antennae and basal third of arista yellow; 3rd segment white pruinose. 3rd segment three times as long as broad, in frontal view almost reaching epistoma. Arista with long regular plumosity, the longest of which slightly exceeds length of 3 rd antennal segment. Parafacialia slender, opposite insertion of arista equal to diameter of anterior ocellus. Parafacialia and genae bare. In lateral view, parafrontalia and parafacialia largely invisible; vibrissal angle projecting slightly beyond profrons. Genae slender; the depth below lowest eye-margin almost equal to width of 3 rd antennal segment. Peristomal setae rather dense, especially behind. Facial ridges with short hairs ascending to level of about lower third of 3 rd antennal segment. Mentum of proboscis dark brown. Palpi brown, tips 
sometimes paler; compressed, weakly clavate towards tips. Thorax: Thorax and scutellum entirely yellow in ground-colour. Viewed from above and behind, mesonotum thinly but uniformly white dusted, with traces of undusted markings as follows: a pair of paramedian vittae before suture mesad of the $d c$; a pair of prst patches between $p h$ and $d c$; and a pair of post vittae between $i a$ and $d c$. Pleura virtually undusted. Spiracles pale yellow. Mesonotum with the ground-setulae short and numerous, especially between the $d c$, all thoracic ground-setulae black unless otherwise stated. Acr o $+\mathrm{I}$, the single $(p r s c)$ pair quite strong, closer to each other than to the $d c$. All $d c$ setae strong. $2 h$, the outer one one and a half times length of the inner one. $2 \mathrm{ph}$, the posterior one twice length of the anterior one. $2 i a$, the anterior one fine. $2 s a$, the posterior one weak. Post-alar callus with 2 setae. Post-alar declivity with a few scattered pale hairs. Supra-squamal ridge bare. Propleural depression bare. I propleural and I prostigmatal seta, each with a dark auxiliary seta below; the former surrounded by few, the latter by numerous, setulae. Ist $n p l$ longer and stronger than $2 \mathrm{nd}$; disc of notopleuron with several setulae around the bases of both setae. Mesopleuron with 4 strong setae in caudal row, and a conspicuous black setula in upper anterior corner. Infra-alar bulla yellow, bare. Pteropleuron with the setulae on sub-alar ridge confined to anterior part, descending down to sternopleural and hypopleural margins. Stpl I +2 , the lower one weaker than the anterior one and much closer to posterior one than to anterior one. Metathoracic spiracle moderate, rather oval, with a row of black setulae along lower margin. Squamopleuron with pale hairs. Scutellum with a very strong apical and sub-basal lateral pair of setae. Disc with rather short dense setulae, a few stronger ones apically. Legs: Yellow; fore tibia brown, mid and hind tibiae and all tarsi black; tibiae and tarsi yellow in Cairns $\widehat{\jmath}$. Tarsi unremarkable. Fore femur without av setae, with a complete row of $p v$ setae. Mid femur without $a v$ or $p v$ setae except for the usual erect setulae basally and the $p v$ in basal third; I $a$ and $3 d-p$ preapical setae. Mid tibia with $2 p$ setae. Hind femur with 3-4 preapical $a v$ setae; $a d$ row complete; I $p d$ preapical seta. Hind tibia with I $a d$ and I weaker $a v$ setae; sometimes some of the $p d$ ground-setulae more erect in apical half; $d$ preapical seta subequal to tibial depth, shorter than the ad. Wings: Clear; the veins brown. Epaulet and basicosta yellow. Subcostal sclerite bare. Costa setulose ventrally as far as the apex of vein 2, the spine inconspicuous. Stem-vein bare above, with some inconspicuous pale hairs below. Small cross-vein placed basad of the point where vein I enters costa. Hind crossvein oblique, strongly sinuate. Vein I bare. Vein 3 bare above; below with a few setulae on the node at base extending a little way to small cross-vein. Vein 4 inclined weakly forward towards vein 3 in apical section. Squamae whitish, margins yellow, fringes pale. Knob of halteres yellow. Abdomen: Tergite 5 wholly dark, or yellow with a pair of black lateral spots. Sternites yellow. Macrochaetae poorly developed: tergite 4 with lateral discals, the marginal row interrupted medially; tergite 5 with a marginal row and some lateral discals. Genitalia: Text-figs. 7I, 74, 77. Measurements: Length of body, $6.5 \mathrm{~mm}$. Length of wing, $6 \cdot 0 \mathrm{~mm}$.

ㅇ. Differs from the male as follows. Head: Eyes broadly separated; frons at middle less than an eye-width, broadening gradually to lunula. Upper inner eye-facets not enlarged. Ocellar setae strong, equal to 2nd prst $d c$ seta, directed forwards and slightly outwards. The incurved vti not much longer than the outcurved vte; pvt outcurved, weak, about half length of vte. Parafrontalia silvery white pruinose on lower quarter only, otherwise grey pruinose, subshining black alongside ocellar tubercle; genae sometimes black in ground-colour, in which case grey pruinose. Interfrontalia, in mature specimens, black in ground-colour; viewed from below, greyish pruinose but rather brownish tinged on frontal triangle; frontal triangle otherwise visible as an ill-defined black streak extending half distance from anterior ocellus to lunula. Parafrontalia slender, broadening gradually towards lunula; at middle equal to about twice diameter of anterior ocellus, at lunula broader than width of 3 rd antennal segment. Interfrontalia with the margins convex, broadest at middle of frons, at lunula subequal to a parafrontale, bare. 3-4 pairs of inclinate ori on lower three-fifths of frons, only the lowest pair really strong, with a few interstitials; 2 pairs of reclinate ors, the upper pair twice as long as lower and placed closer to it than to vti; parafrontalia otherwise with short proclinate setulae on most of length. 3rd antennal segment weakly infuscated in apical half. Parafacialia slightly broader, opposite insertion of arista slightly broader than diameter of anterior ocellus. Beard often with rather numerous pale setae among the black 
ones. Thorax: Viewed from above and behind, mesonotum and scutellum undusted except on humeri. Prsc acr placed on the transverse level of prsc dc. Notopleuron with fewer setulae. Squamopleuron with some dark hairs. Legs : Yellow, fore tibia yellow, mid and hind tibiae and all tarsi brown to black. Mid femur with only 3-4 short pv setae in basal third, none as long as femoral depth. Hind femur with 2 preapical av setae, with a few longer setulae on this surface. Wings: Clear or rather yellowish tinged. Vein 3 bare above or with a setula on the node at base. Squamae yellowish. Abdomen: Colour as in male. Macrochaetae reduced and very weak. Measurements: Length of body, 6.5-7.0 $\mathrm{mm}$. Length of wing, 6.0-6.5 $\mathrm{mm}$.

Holotype ô. QueEnsland: 6 miles N. of Kuranda, ir.i.rg67 (D. K. McAlpine E G. Holloway), Aust. Mus.

Paratypes, 4 ô, 9 ㅇ. Queensland: Bamaga, Cape York, 2 fิ, I + , 28.iii. I964 (I. F. B. Common and M. S. Upton), I ô BMNH, I ô, I ㅇ, CSIRO; I 9 (Brunetti Coll.), BMNH; Kuranda, I ô, x. I9Io (Brunetti Coll.), BMNH; Kuranda, I, Ioo ft., I + , 3.v-20.vi.IgI3 (R. E. Turner), BMNH; Mt. Molloy, I ㅇ (F. H. Taylor), SPHTM; Crystal Cascades, Cairns, I ㅇ, I9.iv. Ig67 (D. H. Colless), CSIRO; Whitfield Range Forest Reserve, Cairns, I + I9.iv. I967 (D. H. Colless), CSIRO; Upper Mulgrave River, Io m. Goldsborough Road, I 9, 9.v.I967 (D. H. Colless), CSIRO; Kuranda, 350 m., rain forest, I ô, 6.v. I96I (L. \& $M$. Gressitt), Bishop; Mulgrave River 4 miles W. of Gordonvale, 2 + 2 and I2.i.rg67 (D. K. McAlpine), Aust. Mus.

Two females have rather aberrant features and may be either aberrant australis or vicaria, or hybrids between the two. Hind femur with a few $p v$ setae in basal third, not as strong as in other females of australis but stronger than in vicaria, and with only the single $d$ preapical seta of vicaria. The abdominal pattern is that described for australis. These are not paratypes of australis:

Not paratypes, Queensland: Iron Range, I + , Ir.iv. I964 (I. F. B. Common \& M. S. Upton), CSIRO; Lake Barrine, I +, 25.ix.I937 (A.J. Turner), Qld. Mus.

Distribution and biology: Australia: Queensland. A rare species.

This species occurs up to $350 \mathrm{~m}$. and has been found exclusively in rain forest. Life-history and immature stages unknown.

Affinities: This species is very close to several species of the vicaria-group that also possess $p v$ setae on hind femur and enlarged upper inner eye-facets in the male sex: mariana Snyder, trukensis Snyder and saperoi Bohart and Gressitt, all from Micronesia and known to me only from descriptions, and fumicosta fumicosta Malloch and fumicosta savaii Malloch, both from Samoa and known to me from material in the BMNH. D. fumicosta s.l. has proternal setulae yellow and pteropleural setulae as in australis (savaii) or entirely black (fumicosta); the wings are very conspicuously darkened, and the stem-vein has a few pale hairs on dorsal surface.

It differs from megophthalma Malloch by the characters given in the key and by the dark fasciae on abdominal tergites 3 and 4 .

Discussion: The female from Kuranda (Turner) bears Malloch's determination label "Dichaetomyia decipiens Stein?", but this record was not published. Mydaea decipiens was distinguished by Stein (I9I8 : I85) from vicaria (as rufa Stein) by the presence of $p v$ setae on hind femur. This, and Malloch's discussion of rufa and decipiens (I929b : I7I-I72), account for this determination. My identification of the 
female of australis is based upon a small series of both sexes from the same population, and I have previously shown (Pont, I968: I69) that decipiens is a species of the Mydaeine genus Papuaia Malloch and not of Dichaetomyia.

\section{Dichaetomyia vicaria (Walker)}

(Text-figs. I, 9, II, I3, 72, 75, 78)

Aricia vicaria Walker, 1859 : 130. Holotype 9 , Key Island (= KaI Island). In the British Museum (Natural History), London. [Examined.]

Spilogaster rufa Stein, 1900b : I32. Lectotype $\hat{\jmath}$, NEw Guinea: Friedrich Wilhelmshafen (= Madang). In the Zoologisches Museum der Humboldt-Universität zu Berlin. [Examined.] [Designation by Pont, in press.] syn. n.

Dichaetomyia rufa (Stein) Malloch, I925: 326 .

Dichaetomyia rufa var. personata Bezzi, I928: 176. Lectotype ô, Fijı: Suva. In the British Museum (Natural History), London. [See designation below.] syn. n.

Dichaetomyia rufa (Stein); Malloch, I929a: 405 .

Dichaetomyia rufa (Stein); Malloch, 1929b : 169-172.

Dichaetomyia rufa var. personata Bezzi; Malloch, I929b : I70-172.

Dichaetomyia rufa (Stein); Lee, Crust \& Sabrosky, 1956 : 332.

Dichaetomyia rufa (Stein); Snyder, 1965: 301.

Dichaetomyia vicaria (Walker) Pont, I966a : 98.

Dichaetomyia rufa (Stein); Given, I968: 42.

Dichaetomyia rufa (Stein); Pont, in press.

Lectotype designation for var. personata Bezzi. Bezzi described his rufa var. personata from "Type ô and + , Suva, 8.ix.I920 (H.W. Simmonds), Natova, Nadi, ix. I9I4 (R. Veitch)". This statement does not restrict the name to one specimen, and so lectotype designation is necessary. I have labelled, and designate herewith, the male from Suva as LECTOTYPE and the female from Natova, Nadi, as paralectotype. Both specimens are in the BMNH. A male syntype from Natova in Milan has been labelled as paralectotype.

Diagnosis: $D$. vicaria can be distinguished from the other Australian species of the vicaria-group with black and yellow pteropleural setulae by the absence of $p v$ setae on hind femur, the ground-setulae never exceeding half femoral depth (Text-figs. 9 and I3) and by the absence of dark fasciae on tergites 3 and 4 .

o. Head: Eyes virtually bare, with only the usual microscopic pubescence. Ocellar setae quite strong, but not as long as anterior prst $d c$. Vertical setae short, only slightly longer than the adjacent post-ocular setulae. Post-ocular setulae very short, with several scattered setulae below the upper row that usually include some pale ones, sometimes entirely black. Parafrontalia and parafacialia silvery white pruinose, face more thinly so; genae reddish to black in ground-colour, brownish grey to grey pruinose. Interfrontalia, viewed from below, with the visible parts grey pruinose. Parafrontalia slender, at lunula equal to just under twice diameter of anterior ocellus. Interfrontalia reduced, two small triangles visible before ocellar tubercle and at lunula, visible as a line or even obsolete on median third of frons. 2-3 pairs of inclinate ori, only the lowest pair really strong, with several hair-like interstitials, all on lower two-fifths of frons; I pair of hair-like reclinate ors just before ocellar tubercle. Antennae and basal third of arista yellow; 3rd segment white pruinose. 3rd antennal segment three times as long as broad, in frontal view almost reaching epistoma. Arista with long regular plumosity, the longest of which equals or slightly exceeds length of 3rd antennal segment. Parafacialia slender, opposite insertion of arista equal to just over diameter of anterior ocellus. Parafacialia and genae bare. In 
lateral view, parafacialia and parafrontalia visible though slender; vibrissal angle projecting slightly beyond profrons. Genae slender; the depth below lowest eye-margin equal to slightly less than width of 3 rd antennal segment. Peristomal setae rather dense, especially behind. Facial ridges with short hairs ascending to level of about lower third of 3 rd antennal segment. Mentum of proboscis brown. Palpi usually wholly brown, sometimes yellow in apical half and only weakly infuscated in basal half; compressed, weakly clavate towards tips. Thorax: Thorax and scutellum entirely yellow in ground-colour. Viewed from above and behind, mesonotum whitish dusted, more densely so before suture, with a pair of slender undusted paramedian vittae before suture, mesad of the $d c$, continued a short distance behind suture, a pair of undusted prst patches between $p h$ and $d c$, and a pair of weakly dusted post vittae between $i a$ and $d c$. Pleura virtually undusted. Spiracles pale yellow. Mesonotum with the ground-setulae short and numerous, especially between the $d c$, all thoracic ground-setulae black unless otherwise stated. $A c r$ o $+\mathrm{I}$, the single (prsc) pair quite strong, closer to each other than to the $d c$. All $d c$ setae strong. $2 h$, the outer one one and a half times length of the inner one. $2 p h$, the posterior one twice length of the anterior one. $2 \mathrm{ia}$, the anterior one short and fine, sometimes absent. $2 \mathrm{sa}$, the posterior one weak. Post-alar callus with 2 setae. Post-alar declivity with a few scattered pale hairs. Supra-squamal ridge bare, in some specimens with some dark or pale setulae at anterior (outer) end, near wing-base; this area often obscured by the wing. Propleural depression bare. I propleural and I prostigmatal seta, each with a well-developed black auxiliary seta below; the former surrounded by few, the latter by numerous, setulae. Ist $n p l$ longer and stronger than 2nd; disc of notopleuron with several pale or dark setulae around the bases of both setae. Mesopleuron with 4 strong setae in caudal row, and a conspicuous black setula in upper anterior corner. Infra-alar bulla yellow, bare. Pteropleuron with the setulae on sub-alar ridge confined to anterior part, descending down to sternopleural and hypopleural margins. Stpl I +2 , the lower one weaker than anterior one, occasionally subequal to it, and much closer to posterior one than to anterior one. Metathoracic spiracle moderate, subtriangular, with a row of black setulae along lower margin. Squamopleuron with a number of dark, dark and pale, or pale hairs. Scutellum with a very strong apical and sub-basal lateral pair of setae. Disc with rather short dense setulae, a few stronger ones apically. Legs: Yellow, tarsi brown; fore tibia yellow, mid tibia dull yellow, hind tibia brown, or mid and hind tibiae dull yellow or brown, or all tibiae yellow. Tarsi unremarkable. Fore femur without av setae, with a complete row of $p v$ setae. Mid femur without $a v$ or $p v$ setae; I $a$ and $3 d-p$ preapical setae. Mid tibia with $2 p$ setae. Hind femur with $a v$ surface bare except, in apical two fifths, for I-3 strong setae that are as long as femoral depth and 2-3 weak short ones before them; $a d$ row complete; i pd preapical seta. Hind tibia with I (-2) ad and I-2 av setae; sometimes some of the pd ground-setulae more erect in apical half; $d$ preapical seta subequal to tibial depth, shorter than the ad. Wings: Very weakly yellow tinged, sometimes quite strongly so basally and costally; the veins pale. Epaulet and basicosta yellow. Subcostal sclerite bare. Costa setulose ventrally as far as the apex of vein 2, the spine inconspicuous. Stem-vein with a few fine pale inconspicuous hairs on lower, and often also on basal part of upper, surfaces. Small cross-vein placed basad to apicad of the point where vein I enters costa. Hind cross-vein oblique, strongly sinuate. Vein I bare. Vein 3 bare or with I setula on the node at base above; below with a few setulae on the node at base and just beyond. Vein 4 inclined weakly forward towards vein 3 in apical section. Squamae pale yellow to yellow. Knob of halteres pale yellow. Abdomen: Ground-colour yellow, most of tergites 4 and 5 usually discoloured by post-mortem decay. Sternites yellow. Macrochaetae quite well developed: tergite 3 with some lateral marginals, tergites 4 and 5 each with a complete marginal row, tergite 4 with some lateral discals, and tergite 5 with a discal row. Genitalia: Text-figs. 72, 75, 78. Measurements : Length of body, $6 \cdot 0-7 \cdot 0 \mathrm{~mm}$. Length of wing, 5.5-6.5 mm.

ㅇ. Differs from the male as follows. Head: Eyes broadly separated; frons at middle less than an eye-width, broadening gradually to lunula. Upper inner eye-facets not enlarged. Ocellar setae strong, equal to 2nd prst dc seta, directed forwards and slightly outwards. The incurved $v t i$ not much longer than the outcurved vte; pvt outcurved, about half length of vte. Parafrontalia silvery white pruinose on lower third only, otherwise grey pruinose, subshining black alongside ocellar tubercle. Interfrontalia black in ground-colour, sometimes reddish towards 
lunula; viewed from below, grey pruinose but weakly brownish tinged on frontal triangle; frontal triangle otherwise visible as an ill-defined black streak extending a little over half distance from anterior ocellus to lunula. Parafrontalia slender, broadening gradually towards lunula; at middle equal to about twice diameter of anterior ocellus, at lunula broader than width of 3 rd antennal segment. Interfrontalia with the margins convex, broadest at middle of frons, at lunula slightly broader than a parafrontale, bare. 3-4 pairs of inclinate ori on lower half of frons, only the lowest pair really strong, with few interstitials; 2 pairs of reclinate ors, the upper pair twice as long as lower and placed closer to it than to vti; parafrontalia otherwise with short proclinate setulae on most of length. 3rd antennal segment infuscated in apical half. Parafacialia slightly broader, opposite insertion of arista slightly broader than diameter of anterior ocellus. Thorax: Viewed from above and behind, mesonotum and scutellum undusted except on humeri. Anterior $i a$ sometimes absent. Notopleuron with fewer setulae, occasionally a few pale ones, sometimes almost absent. Hypopleuron sometimes without the pale hairs below spiracle. Legs : Mid femur without denser erect $a v$ and $p v$ ground-setulae, in basal half with a few short $p v$ setae that are not more than half femoral depth. Hind femur with $\mathrm{I}-2$ strong and $\mathrm{I}-2$ weak av setae in apical third. Wings: Stem-vein with the dorsal hairs often hardly discernible. Abdomen: Colour as in male. Virtually undusted in posterior view, even on the darkened areas, but appearing matt. Macrochaetae reduced, weak, confined to lateral parts of tergites. Measurements: Length of body, $5 \cdot 5-7 \cdot 0 \mathrm{~mm}$. Length of wing, $5 \cdot 0-6 \cdot 5 \mathrm{~mm}$.

Material examined. Holotype + of vicaria. Key Island (= KaI IsLand) (A.R. Wallace), BMNH.

Lectotype $\sigma^{\wedge}$ of $r u f a$, N.E. New Guinea: Friedrich Wilhelmshafen (= Madang), I896 (L. Biró), ZMB.

Lectotype ô of rufa var. personata, Fiji Islands: Suva, 8.ix.I920 (H. W. Simmonds), BMNH.

Torres Strait: St. Paul Moa Is., I ô, I2.ii.rg62 (D. W. Lavers), CSIRO; Saibai Is., I 9 , ro.ii. I962 (D. W. Lavers), CSIRO.

Northern TERritory : 4 mile Marrakai, I ô, I3.ix. I933 (T. G. Campbell), CSIRO; Humpty Doo, I우 2 2iv. I959 (I. F. B. Common), CSIRO; Darwin Harbour, I 우 I4.vi.rg64 (K. R. Norris), CSIRO; Brock's Creek, I ㅇ, i.I933 (T. G. Campbell), CSIRO; Bill's Point, Mary River, I +, 3.viii.I929 (I. M. Mackerras and T. G. Campbell), CSIRO; Brock's Creek, I ㅇ, 8.iii.I933 (F. Don), CSIRO; East Point, Darwin, I ô, I ㅇ, I2.vi.Ig64 (K. R. Norris), CSIRO; Howard Springs, I2 ô, I5 ㅇ, I2.vi. I964 (K. R. Norris), 3 ô, 4 ㅇ BMNH, 9 ô, II ㅇ CSIRO; Burnside, attracted to and feeding in human excrement, I ô, 28. iii.I929 (T. G. Campbell), CSIRO; Brock Creek, Burnside, I ㅇ, 29.iii.I929 (T. G. Campbell), CSIRO; Katherine, $2 \hat{0}, 6$ ㅇ, I5-

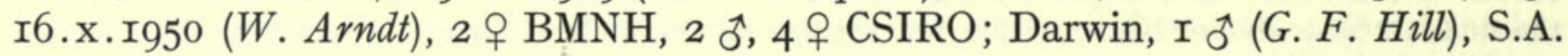
Mus.; Koolpinah, 4 ㅇ (G. F. Hill), S.A. Mus.; Batchelor, I + (G. F. Hill), Vict. Mus.; Crocodile Islands, 7 ㅇ, 28.xi.I924 (G. H. Wilkins), BMNH; Arnhem Land, Maningrida, I ô, 20-2r.iii.rg6r (L. \& $M$. Gressitt), Bishop; Arnhem Land, Maningrida, 5 m., Malaise-trap, I ô, 2 오 I7.iii. I96r (J. L. \& M. Gressitt), Bishop; Holmes Jungle, Palm Creek, I5 km. N.E. of Darwin, 5 m., light trap, I ㅇ, Ir.iii.I96r (J. L. \& $M$.

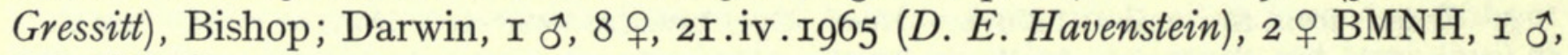
6 오 CSIRO.

Queensland: Ayr, 2 ô, 2 ㅇ, 4.ix.I950 (E. F. Riek), CSIRO; Mt. Bartle Frere, East base, $80 \mathrm{ft}$., I ô $^{2} 24$.iv. I955 (K.R. Norris), CSIRO; I2 miles S.E. of Bowen, I +, 6.v.I955 (K.R. Norris), CSIRO; 4 miles S. of Atherton, I +, 2.v.I955 (K.R. Norris), 
CSIRO; Yeppoon, I 이 Io.v.I955 (K. R. Norris), CSIRO; Kairi, I ㅇ, 2.v.I955 (K. R. Norris), CSIRO; 8 miles E. of Netherdale, I +, 6.v.I955 (K.R. Norris), CSIRO; Kuranda, I ô, I7.v.I958 (D. K. McAlpine), Aust. Mus.; River Bank, rain forest, Silkwood, Innisfail District, I +, 25.v.I958 (D. K. McAlpine), Aust. Mus.; Bramston Beach, near Innisfail, open savannah, I +, 30.iv. I967 (D. H. Colless), CSIRO; Springsure, I + , 2.iii.I965 (D. E. Havenstein), CSIRO; Kuranda, I 9 , 2I.viii.I95I (A.H. Wetherley), CSIRO; I4 miles S.W. of Sarina, 4 ô, I o, 8.v.I955

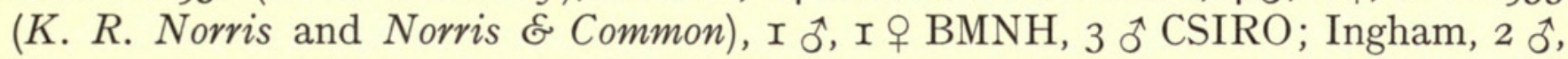
I + , II.vii.I959 (K. L. Harley), CSIRO; Ingham, trapped over dead cattle ticks, 5 ô, 2 ㅇ, 9-I3. vii. I959 (K. L. Harley), I ô BMNH, 4 ô, 2 क CSIRO; Ingham, trapped over

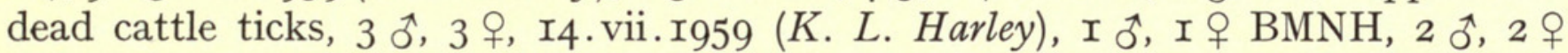
CSIRO; Ingham, I ㅇ, I3.iii.I958 (K. L. Harley), CSIRO; Ingham, 4 + , 22.v.I958 (K. L. Harley), I + BMNH, 3 ㅇ CSIRO; Ingham, light trap, I ㅇ, 3.v.Ig6r $(R$. Straatman), CSIRO; Cannonvale, near Proserpine, I ô, 24.vi.I958 (T. G. Campbell), CSIRO; Innisfail, I ô, 2I.iv. I958 (T. G. Campbell), CSIRO; Rockhampton, I ô, 6 q, I9.ix.I963 (D. E. Havenstein), 2 ㅇ BMNH, I ô, 4 ㅇ CSIRO; Redlynch, 2 đૈ, 4 ㅇ, I4. viii.I938, and 40ิ, I우, Io-I7.viii.I938 (R. G. Wind), BMNH; Burpengary, I우 (T. L. Bancroft), BMNH; Cairns, ex corn, I ơ (A. P. Dodd), USNM; Mt. Glorious, 2 으, I3.ii. I96r (L. \& M. Gressitt), BMNH and Bishop; Hambledon, I 우 xii.rg2I (Pemberton), Bishop; Cairns, ex corn, $2 \sigma^{\star}(J . F$. Illingworth), BMNH and Bishop; Cairns, coll ex cage, I $\hat{\sigma}$, I + ( $J$. F. Illingworth), Bishop; Cairns, coll ex window, I $\hat{\sigma}(J . F$. Illingworth), Bishop; Cairns, coll. ex castor oil plant, I + (J. F. Illingworth), Bishop; Brisbane, in house, I $\sigma^{\star}(A . J$. Turner), SPHTM; Townsville, I + (Taylor), SPHTM; Big Mitchell Creek, Mareeba-Molloy Road, I ô, 4.v.I967 (D. H. Colless), CSIRO; Hyacinth Pool, Ingham, 2 ô, 27.viii.I955, CSIRO; Earl Hill, N. of Cairns, I + , 8.v.I967 (D. H. Colless), CSIRO; Jungle swamp, Vorkey's Knob, near Cairns, I ㅇ, 20. viii. I955, CSIRO.

Amboina Is. (= Ambon Is.): I $\hat{\jmath}$ (F. Muir), Bishop.

BuRu Is.: Station I, 2 ㅇ, I3.xii.I92I and 8.i.I922 (L. J. Toxopeus), Amsterdam [det. by Malloch as rufa].

WeST IRIAN : Vogelkop, Fak Fak, S. coast of Bomberai, ro-Ioo m., I f^, II. vi. I959 (T. C. Maa), Bishop; Vogelkop, Manokwari, 75 m., I ô, 20.vii.I957 (D. E. Hardy), Bishop; Hollandia, I ㅇ, 24.i. I96o (T. C. Maa), Bishop; Eramboe, 8 km. ex Merauke, I +, 5.ii.rg6o (T. C. Maa), Bishop; Hollandia, I đૈ, vii.r957 (G. den Hoed), Amsterdam.

N.E. New Guinea: Morobe District, Lae area, Busu River Forest, I ô, I7 .vi.r 965 (R. W. Crosskey), BMNH; Madang District, near Madang, I ô, 9-I4.vi.I965 (R. W. Crosskey), BMNH; Dreikikir, Sepik District, 350 m., Malaise-trap, I ô, 23.vi. I96I (J. L. \& M. Gressitt), BMNH; Wampit V., near Gurakor Village, 950 m., near Wau, I ô, 7.vii.I957 (D. E. Hardy), BMNH; Maprik, I50 m., I ô, 29.xii.I959-I7.i.I960 (T. C. Maa), Bishop; May R./Patrol Station, roo m., swept near stream, I +, 30.v. I963 (R. Straatman), Bishop; Lae., I ㅇ, vii.I944 (F. E. Skinner), Bishop; Aitape, 3 ô, 4 우 (F. H.Taylor), SPHTM; Wau, Morobe District, I, 200 m., Malaise-trap, I ô, I4 . vi. I96r (J. L. Gressitt), Bishop; Wau, Morobe District, I,Ioo m., I ô, I9.ix.I96r (J. Sedlacek), Bishop; Wau, Morobe District, I,200 m., M.V. Light Trap, I +, 7-I6.xii.rg6r ( . 
Sedlacek), Bishop; Wau, Morobe District, I,200 m., M.V. Light Trap, I $9,26-$ 29.ix. I96I (J. Sedlacek), Bishop; Lae, Io m., 2 of 6. vii.I957 (D. E. Hardy), BMNH and Bishop; Lae, ro m., 2 ऊ, I +, Io.vii.I957 (D. E. Hardy), Bishop; Lae, Bubia Agric. Sta., I5 m., I ㅇ, 6. vii.I957 (D. E. Hardy), Bishop; Finsch Haven, 4 ㅇ (L. Wagner), I BMNH, 3 S.A. Mus.; Lae, I +, 24.xii. I963 (D. K. McAlpine), Aust. Mus.; Kandanggei, Sepik River, I ô, 2.iii.rg64 (D. H. Colless), CSIRO; Angoram, Sepik River, I ô, X.I959 (R. Pullen), CSIRO.

PAPuA: Mafulu, 4,000 ft., I ô, xii.I933 (L. E. Cheesman), BMNH; Cape Rodney, Malaise-trap, 2 ô, 3 ㅇ, 2-4.xi. I96o (J. L. Gressitt), I ㅇ BMNH, 2 đ, 2 ㅇ Bishop; Cape Rodney, Malaise-trap, I +, 2.xi. I96o (J. L. Gressitt), Bishop; Cape Rodney, ro m., Malaise-trap, I +, 2-4.xi.rg6o (J. L. Gressitt), Bishop; Central District, Otomata

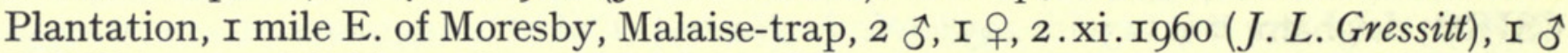
BMNH, I $\widehat{o}$, I $q$ Bishop; Central District, Otomata Plantation, I mile E. of Moresby, Malaise-trap, I + , 9.30-I8.00 (J. L. Gressitt), BMNH; Kapogere, near Rigo, I ô, I +, I4-I9.v.I959 (C. D. Michener), Bishop; West District, Oriomo Govt. Sta., Malaisetrap, I $9,26-28$. x. I96o (J. L. Gressitt), Bishop; Normanby Is., Wakiuna, Sewa Bay, I +, 25-30.x.I956 (W.W. Brandt), BMNH; Port Moresby, Boroko, Malaise-trap, I ô, 6-7.xi.rg6o (J. L. Gressitt), Bishop; Central District, Kapogere, 60 miles S.E. of Port Moresby, 4 ㅇ, 2.v.I965, and I ㅇ, 4.v.I965 (R. W. Crosskey), BMNH; Moitaka, Port

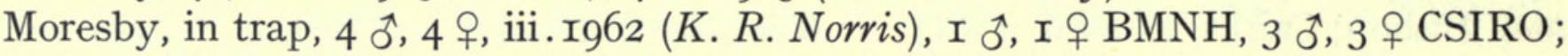
Moitaka, Port Moresby, I ô, iii.I962 (K. R. Norris), CSIRO; West District, Maderi Plantation, I ô, x.I96I (M. G. Meadows), CSIRO.

Bismarck Archipelago: New Britain, Linden, I ô (Heydon), S.A. Mus.; Rabaul, on damaged corn cobs, I $\widehat{0}$, I8.vi. I94I (J. L. Froggatt), BMNH; Keravat, I $\hat{o}$, I5.v.I94I (J. L. Froggatt), BMNH; Keravat, I +, 4-5.vii.rg65 (R. W. Crosskey), BMNH; Keravat, I +, 23.vii.I953 (G. S. Dun), BMNH; Malmalwan-Vunakanau, Gazelle Peninsula, 2 ㅇ, 5-I2 \& I4.v.I956 (J. L. Gressitt), Bishop; south of Cape Hoskins Aerodrome, 8 ô, I q, 6. vii. I962 (Noona Dan Exped. I96I-62), 2 ô BMNH, 6 ô, I ㅇ Copenhagen; Valoka, I ô, 8. vii. I962 (Noona Dan Exped. I96I-62), Copenhagen; Yalom, I,000 m., 4 ô, 8.v.I962, 4 ô, Io.v.I962, I +, I3.v.I962, and I + , 20.v.I962 (Noona Dan Exped. I96I-2), 2 o BMNH, 6 o , 2 ㅇ Copenhagen. New Ireland, "Camp Bishop ", I2 km. up Kait River, 240 m., I ô, ro.vii.I956 (E. J. Ford), Bishop; Gilingil Plain, 2 m., 2 ㅇ, 6.vii.r956, light trap, I ㅇ, 4.vii.r956, and I ㅇ, 5.vii. I956 (J. L. Gressitt), I BMNH, 3 Bishop; Lemkamin, I ô, Ir.iv. I962 (Noona Dan Exped. I96I-62), Copenhagen; Danu, Kalili Bay, 7 ô, 2 ㅇ, 29.iv. I962 (Noona Dan Exped. Ig6I-62), 2 ô, I $ᄋ$ BMNH, 5 ô, I $q$ Copenhagen. Manus Is., Lorengau, I-75 m., I ô, 28.vi.I959 (J. L. Gressitt), BMNH. Lavongai, Banatam, caught in Malaise-traps, 2 + , 25.iii.I962, and I + , I9.iii. I962 (Noona Dan Exped. I96I-62), I BMNH, 2 Copenhagen. Mussau Is., Boliu, 2 ô, 3.vi. I962 (Noona Dan Exped. I96I-62), Copenhagen; Malakata, 2 ơ, 9.vi.I962 (Noona Dan Exped. I96I-62), BMNH and Copenhagen. Duke of York, Manuan, 4 ô, 4 ㅇ, I8. vii.I962 (Noona Dan Exped. I96I-62), I 소. I 오 BMNH, 3 oै, 3 우 Copenhagen.

Louisiade Archipelago: Misima Island, i + (R. J. Andrere), S.A. Mus.

Solomon IsLANDS: I ㅇ, vii-viii. I909 (Froggatt), CSIRO; Bougainville (S.), Kieta, I ô, 26.xi.I959 (T. C. Maa), Bishop; Kolombangara Is., Kukundu, S.W, coast, 
I-I2 m., ex fresh human excrement, I ô, 8-Ir.vii.I959 (J. L. Gressitt), Bishop; Kolombangara Is., I-I2 m., I ô, 8.vii.I959 (J. L. Gressitt), Bishop; Vella Lavella, Kundurumbangara, 80 m., Malaise-trap, I ô, 23.xi.I963 (J. L. Gressitt), Bishop; Vella Lavella, Pusisama, Malaise-trap, I ô, xi.I963, and I +, 25.xi.rg63 (P. Shanaham), ô BMNH, ㅇ Bishop.

New Hebrides: Pentecost Is., I ô, 20 .vi. I925 (P. A. Buxton), BMNH; Espiritu Santo, Hog Harbour, I ㅇ, viii. I925 (P. A. Buxton), BMNH; Malekula, I ㅇ, I4 . vi. I925 (P. A. Buxton), BMNH; Malekula, Ounua, 2 + , ii \& iii-iv.I929 (L. E. Cheesman), BMNH.

Fiji Is. : Natova, Nadi, I +, ix.I9I4 (R. Veitch), BMNH, paralectotype of personata; Natova, I $\hat{o}(R$. Veitch), Milan, paralectotype of personata; Suva, I 9,24 . iii. I924 (H. W. Simmonds), BMNH; Ovalau, 2 + (A. M. Lea), S.A. Mus.; Taveuni, I + , May (A. M. Lea), S.A. Mus.; I ô, I9I3 (J.F. Illingworth), Bishop; Kadavu, I + (R. A. Gibbons), SPHTM.

SAmoA: Apia, Upolu, I ô, 3.iii.I924 (P. A. Buxton \& G. H. E. Hopkins), BMNH [det. by Malloch as rufa]; Apia, Upolu, I ô, 9.vi.I924 (Buxton \& Hopkins), BMNH; Apia, I ô, I9.ii.rg23 (J.S. Armstrong), BMNH.

Tonga: Fofoa Is., in trap baited with decaying meat, 2 ㅇ, 29.iv.I949 (B.A. O'Connor), BMNH; Vavan, I + (C. L. Edwards), BMNH.

Distribution and biology: Australia: Torres Strait (St. Paul Moa and Saibai Is.), Northern Territory, Queensland. Kai Is., Ambon Is., Buru Is., New Guinea (West Irian, N.E. New Guinea, Papua), Bismarck Archipelago, Louisiade Archipelago, Solomon Is., New Hebrides, Fiji, Samoa, Tonga. Also recorded from Micronesia (Snyder, I965: 30I) and Niue Is. (Given, I968:42).

In Australia this is the most abundant and generally distributed species of Dichaetomyia, occurring from sea-level to $330 \mathrm{~m}$. It is most commonly found in rain forest, even in narrow riverine rain forest in dry savannah or residual rain forest in agricultural land, but is also found less commonly in eucalyptus forest, open savannah or open country, even near the sea-shore. It has been collected on corn, castor oil plants, dead cattle ticks and human excrement, and has been found indoors. It has been trapped in Malaise-traps, light traps, and carrion-baited blowfly traps.

In New Guinea it occurs up to I,300 m., and has been caught in Malaise-traps and blowfly traps. In New Britain it occurs up to I,000 $\mathrm{m}$. and has been found on damaged corn cobs. In the Solomon Islands it has been found on human excrement, and in Tonga in a fly-trap baited with rotten meat. Life-history and immature stages unknown.

Variation: D. vicaria is remarkably constant in colour and structure throughout its range. The following notes are based on all the material studied (over 300 specimens).

The beard and post-ocular setulae are sometimes almost entirely black in nonAustralian populations. The palpi only rarely have more than the tips yellow. The anterior ia seta is always poorly developed, and may be absent on one side or totally absent. The anterior (outer) end of the supra-squamal ridge, near wing-base, sometimes bears setulae, as in the subgenus Eumusca Townsend of Musca Linnaeus, but this character is not even of specific value in Dichaetomyia. These setulae may be 
black, as in the lectotype of rufa Stein, or pale. The hairs below spiracle on hypopleuron are sometimes absent in the female. The colour of the tibiae varies between yellow and brown even within the same population. In the male, the mid femur may have some short but distinct setae among the $p v$ ground-setulae near base, and the hind femur also may have a few stronger $p v$ setulae around middle. The stem-vein often has a few fine pale inconspicuous hairs on basal part of upper wing-surface.

Discussion: Malloch was always in some doubt as to the identity of this species (I929b : I7I-I72) but his identification has been checked and found to be correct: the male from Apia, Samoa, 3.iii.I924, to which he refers as $r u f a$, is in the BMNH and is conspecific with the species discussed here as vicaria. I have also studied the two females from Buru (I929a:405) doubtfully referred by Malloch to rufa, and find these identifications to be correct.

Bezzi (I928 : I76) described his var. personata as differing from typical rufa by the dark palpi and black interfrontalia. These characters are in my opinion of no importance in this species and vary according to the degree of maturation. His four syntypes possess the characters of vicaria and I have no hesitation in placing his name in synonymy.

Snyder (I965: 30I-303) has redescribed this species, as $r u f a$, from Micronesian material. His identification is probably correct, but he does not mention any pale setulae among the pteropleurals; he writes " scutellar setulae descend scarcely on to lateral margins ", whereas I find that there are usually 5-7 (range 3-9); he writes " occasionally with one or more short hairs on pleuratergite [= squamopleuron]", whilst I have found such hairs to be invariably present, usually numerous, either dark or pale and dark or pale.

I have seen the specimens recorded by Stein (I920: 80) from the islands of Waigeo and Seram, and do not consider them to be this species.

Affinities: $D$. vicaria is closely related to the other species of this group, but can be clearly separated by the shape of the male 5 th sternite, with its characteristic deep median notch on the surface between the lobes, and by the absence of $p v$ setae on hind femur. Females may sometimes be confused with females of flavohirta and reversa with a few brownish pteropleural setulae on sub-alar ridge, but can be distinguished from these species by the absence of the median spot of white dust on the mesonotum at neck.

\section{Dichaetomyia flavohirta Malloch}

(Text-figs. I4, I7, 20, 79, 82, 85)

Dichaetomyia flavohirta Malloch, I925:326. Holotype $\hat{\delta}$, QueEnsLand: Cairns. In the United States National Museum, Washington. [Not examined.]

Dichaetomyia flavohirta Malloch; Lee, Crust \& Sabrosky, I956 : 317.

Note on type-location: Malloch described this species from the male holotype, female allotype, and $7 \hat{\sigma}, 6$ o paratypes, all from Cairns; and I $\hat{o}$ paratype, from Townsville. Lee, Crust \& Sabrosky (l.c.) give the location of this material as follows: holotype USNM, allotype USNM, 3 paratypes USNM, 2 paratypes SPHTM. 
I was unable to study the holotype, but Mr. G. C. Steyskal kindly checked its identity against my draft key to the vicaria-group, and I have also studied two paratypes from Cairns (USNM) and the paratype from Townsville (SPHTM). In the Bishop Museum and the BM there are $6 \sigma^{\pi}$ and 7 o of this species collected at Cairns by Illingworth. Some, but not all, of these are paratypes.

Diagnosis: D. flavohirta can be distinguished from the other Australian species of the vicaria-group with entirely yellow pteropleural and prosternal setulae in the male sex by the conspicuously enlarged upper inner eye-facets and linear frons, and in the female sex by the stronger and more numerous av setae on hind femur (Text-fig. 20).

๙. Head: Eyes virtually bare, with only the usual microscopic pubescence. Ocellar setae quite weak, a little over half length of anterior prst $d c$. Vertical setae short, only slightly longer than the adjacent post-ocular setulae. Post-ocular setulae very short, with several scattered setulae below the upper row that include some pale ones. Parafrontalia, parafacialia and face silvery white pruinose; genae reddish in ground-colour, brownish grey pruinose. Interfrontalia, viewed from below, with the visible parts grey pruinose. Parafrontalia very slender, at lunula equal to diameter of anterior ocellus. Interfrontalia reduced, two small triangles visible before ocellar tubercle and at lunula. I pair of strong inclinate ori at lunula, with 5-6 moderate to hairlike pairs above them, all on lower two-fifths of frons; I pair of hair-like reclinate ors just before ocellar tubercle. Antennae and basal half of arista yellow; 3rd segment white pruinose. 3 rd segment three times as long as broad, in frontal view almost reaching epistoma. Arista with long regular plumosity, the longest of which slightly exceeds length of 3 rd antennal segment. Parafacialia and genae bare. In lateral view, vibrissal angle projecting slightly beyond profrons. Genae slender; the depth below lowest eye-margin equal to slightly less than width of 3rd antennal segment. Peristomal setae rather dense, especially behind. Facial ridges with only $\mathrm{I}-2$ short hairs above the usual cluster of setulae at vibrissal angle. Mentum of proboscis dark brown. Palpi dull yellowish to brown; compressed, slender, weakly clavate towards tips. Thorax: Thorax and scutellum entirely yellow in ground-colour. Viewed from above and behind, mesonotum whitish dusted, more densely so before suture, with a pair of slender undusted paramedian vittae before suture mesad of the $d c$, sometimes continued a short distance behind suture, a pair of undusted prst patches between $p h$ and $d c$, and a pair of weakly dusted post vittae between $i a$ and $d c$. Scutellum thinly dusted, more densely so in basal lateral corners, usually virtually undusted in apical half. Pleura virtually undusted. Spiracles pale yellow. Mesonotum with the ground-setulae rather fine and erect, dense between the $d c$, black unless otherwise stated; pleural ground-setulae pale unless otherwise stated. $A c r o+\mathrm{I}$, the single ( $p r s c)$ pair strong, closer to each other than to the $d c$. All $d c$ setae strong. $2 h$, the outer one not much longer than the inner one, with a 3 rd (inner) seta. 2 ph, the posterior one twice length of the anterior one. $2 \mathrm{ia}$, the anterior one fine, sometimes absent. 2 sa, the posterior one weak. Post-alar callus with 2 setae. Post-alar declivity with a few scattered pale hairs. Supra-squamal ridge bare. Propleural depression bare. I propleural and I prostigmatal seta, each with a well-developed black auxiliary seta below; the former surrounded by few, the latter by numerous setulae. Ist $n p l$ longer and stronger than 2nd; disc of notopleuron with several setulae around the bases of both setae. Mesopleuron with 4 strong setae in caudal row, and a conspicuous black setula in upper anterior corner. Infra-alar bulla yellow, bare. Pteropleuron with the setulae on subalar ridge confined to anterior part, descending down to sternopleural and hypopleural margins. $S t p l$ I +2 , the lower one weaker than anterior one and much closer to posterior one than to anterior one. Metathoracic spiracle moderate, subtriangular, with a few black setulae on lower margin. Squamopleuron with a number of fine pale hairs. Scutellum with a very strong apical and sub-basal lateral pair of setae. Disc with rather fine setulae, a few stronger ones apically. Legs: Yellow; all tarsi brown to black, metatarsi sometimes yellowish. Tarsi unremarkable. Fore femur without $a v$ setae, with a complete row of $p v$ setae. Mid femur with or without a few 
long fine $p v$ setae in basal third, as long as femoral depth, otherwise without $a v$ or $p v$ setae except for the usual erect ground-setulae in basal half; $1 ~ a$ and $3 d-p$ preapical setae. Mid tibia with $2 p$ setae. Hind femur with the $a d$ row complete; I $d$ and I $p d$ preapical setae. Hind tibia with I strong $a d$ and I-2 weaker $a v$ setae; some of the $p d$ ground-setulae more erect in apical half; $d$ preapical a little longer than tibial depth, shorter than the ad. Wings: Rather yellowish, especially at base; the veins brownish. Epaulet and basicosta yellow. Subcostal sclerite bare. Costa setulose ventrally as far as the apex of vein 2, the spine inconspicuous. Stem-vein bare above, with a few pale hairs below. Small cross-vein placed below the point where vein I enters costa. Hind cross-vein oblique, strongly sinuate. Vein I bare. Vein 3 bare above; below with a few setulae on the node at base and just beyond. Vein 4 inclined weakly forward towards vein 3 in apical section. Squamae and margins pale yellow, fringes pale. Knob of halteres yellow. Abdomen: Ground-colour of tergites and sternites yellow, the apical tergites sometimes discoloured. In posterior view, tergites with some whitish dust, with a narrow undusted median vitta. Macrochaetae quite strong and erect: tergite 3 with some lateral marginals, tergite 4 with several lateral discals and a marginal row, tergite 5 with a marginal and partially double discal row. Genitalia: Text-figs. 79, 82, 85. Measurements: Length of body, $6 \cdot 0-7 \cdot 0 \mathrm{~mm}$. Length of wing, $5 \cdot 5-6 \cdot 5 \mathrm{~mm}$.

ㅇ․ Differs from the male as follows. Head: Eyes broadly separated; frons at middle less than eye-width, broadening gradually to lunula. Upper inner eye-facets not enlarged. Ocellar setae strong, slightly longer than anterior prst $d c$ seta, directed forwards and slightly outwards. The incurved $v t i$ one and a half times as long as the outcurved vte; pvt outcurved, almost as long as vte. Parafrontalia silvery white pruinose on lower third, otherwise grey pruinose, subshining black alongside ocellar tubercle. Genae sometimes black in ground-colour, in which case grey pruinose. Interfrontalia black in ground-colour; viewed from below, grey pruinose with the frontal triangle tinged with brownish; frontal triangle otherwise visible as an ill-defined black streak extending three-quarters distance from anterior ocellus to lunula. Parafrontalia slender, broadening gradually towards lunula; at middle equal to almost twice diameter of anterior ocellus, at lunula broader than width of 3 rd antennal segment. Interfrontalia with the margins convex, broadest at middle of frons, at lunula slightly broader than a parafrontale, bare. 4 pairs of inclinate ori on lower three-fifths of frons, only the lowest pair really strong, with few interstitials; 2 pairs of reclinate ors, the lower pair a little over half length of upper pair, upper pair closer to lower than to $v t i$; parafrontalia otherwise with short proclinate setulae on most of length. Parafacialia slightly broader, opposite insertion of arista slightly broader than diameter of anterior ocellus. In lateral view, parafrontalia and parafacialia visible but slender. Thorax: Viewed from above and behind, mesonotum and scutellum undusted except for a small median patch of white dust at neck. Anterior ia seta sometimes vestigial, or rarely absent. Anterior prosternal setulae sometimes brownish. Prostigmatal and propleural ground-setulae all pale. Hypopleuron sometimes bare below spiracle. Scutellum with o-I setulae below the level of the strong setae. Legs : Mid femur without denser erect $a v$ and $p v$ ground-setulae in basal half, without $v$ setae except for 2-3 short $p v$ setae. Hind femur without $p v$ setae. Wings: Vein 3 sometimes with a setula above on the node at base. Abdomen: Ground-colour yellow, tergites 4 and 5 often mainly to partly infuscated. In posterior view tergites undusted. Macrochaetae reduced and weak: tergites 4 and 5 each with only weak lateral discal and marginal setae. Measurements: Length of body, $6 \cdot 5-7 \cdot 0 \mathrm{~mm}$. Length of wing, $6 \cdot 0-6 \cdot 5 \mathrm{~mm}$.

Material examined. Northern TERritory: Burnside, attracted to and feeding in human excrement, I ô, 28.iii. I929 (T. G. Campbell), CSIRO; Darwin, I + , 2I.iv. I965 (D. E. Havenstein), CSIRO.

Queensland: Cairns, coll ex corn, $3 \hat{\jmath}, 7$ ㅇ (J.F. Illingworth), $2 \hat{\jmath}, 2$ ㅇ BMNH, I $\widehat{0}$, 5 + Bishop; Cairns, coll ex cane, I $\sigma^{t}(J$. F. Illingworth), Bishop; Cairns, coll ex cage, I $\hat{\sigma}$ (J.F. Illingworth), Bishop; Cairns, coll ex window, I ô (J.F. Illingworth), Bishop; Bamboo Station, Coen, I ô, I ㅇ, 2.v.Ig62 (J.R. Byrne), CSIRO; Townsville, I ô paratype, I $q$ (G.F. Hill), SPHTM; Cairns, I o (F. H. Taylor), SPHTM; Big Mitchell 


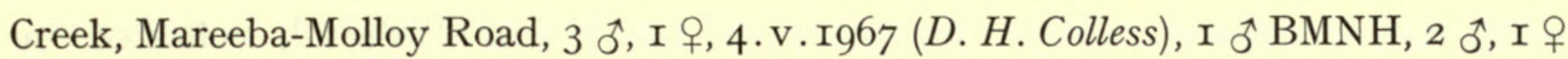
CSIRO; 7-I4 miles W. of Herberton, via Watsonville, 6 ô, 4 ㅇ, I.v.I967 (D. H. Colless), I $\hat{\jmath}$, I 9 BMNH, 5 ô, 3 우 CSIRO; 2 ô (Wainwright Coll.), BMNH; Tolga, near Atherton, I +, 3.i. I959 (D. K. McAlpine), Aust. Mus.; Cairns, coll ex corn, I oิ and I $q$ paratypes ( $J$. F. Illingworth), USNM.

Distribution and biology: Australia: Northern Territory and Queensland. An uncommon species.

This is a lowland species that has been found in tall rain forest, in dry savannah country near watercourses, and in scrub near the seashore. It has been collected on human faeces, and amongst corn and cane. It has also been found indoors.

Life-history and immature stages unknown.

Variation: The species shows some variation in colour, which may be due to differences in age among the specimens examined: the palpi and basal tarsal segments vary from brown to yellowish. In some females the anterior few prosternal setulae may be brown: such females can be distinguished from vicaria and australis by the presence of a median spot of white dust on the mesonotum at neck. The hairs on hypopleuron below metathoracic spiracle are absent in some females. The anterior ia seta is sometimes vestigial, or more rarely, totally absent. In the male the pv setae on mid femur may be well developed or so atrophied as to be scarcely distinguishable from the ground-setulae.

Affinities: D. flavohirta is very similar to reversa and fulvohirta, but males can be easily separated by the conspicuously enlarged upper inner eye-facets and the linear frons. The female is very difficult to separate from reversa, and isolated females of this complex can only be named occasionally by direct comparison with named specimens. The series of females associated with males that I have studied has enabled me to establish the identity of Walker's species and to find small differences between females of the two species.

\section{Dichaetomyia reversa (Walker)}

(Text-figs. I5, I8, 2I, 80, 83, 86)

Sciomyza reversa Walker, I849: ro69. Holotype + , New Holland. In the British Museum (Natural History), London. [Examined.]

Dichaetomyia luteohirta Malloch, $1925: 326$. Holotype of, QueEnsLand: Townsville. In the School of Public Health and Tropical Medicine, Sydney. [Examined.] syn. n.

Dichaetomyia luteohirta Malloch; Lee, Crust \& Sabrosky, 1956 : 346.

Dichaetomyia reversa (Walker) Steyskal, I965: 445.

Note on reversa: Walker described this species from one female from New Holland, presented by J. Hunter. This female, in the BMNH, is the holotype and was studied by Steyskal (l.c.). It is in fair condition, with a few filaments of mould; the fore legs, mid legs, and right hand tarsi are missing. It has the usual Waterhouse label "Scyomyza [sic] reversa Walk. / One of Walker's series so named ". But the data, on a comparatively recent label in Barnett's hand, are " New Holland / J. Bynoe, R.N. / B.M. I844-4". This confusion may be between the collector, Bynoe, and the donor, Hunter. The BMNH register for I844-4 records Diptera from New Holland, 
north and north-west coasts, presented by the Haslar Hospital, collected by Bynoe, the surgeon on H.M.S. "Beagle". I have no doubt that this female is the holotype. The identity is difficult to establish, as females of this part of the vicariagroup are extremely similar, but I am satisfied that revers $a$ is identical with the species hitherto known as luteohirta.

Note on luteohirta: Malloch described this species from the "type, male, one male paratype, and allotype" from "Townsville, Queensland (H. Priestly)". I have studied these three specimens that are located, as stated by Lee, Crust \& Sabrosky (1.c.), in the SPHTM (holotype and allotype) and the USNM (paratype). The holotype was collected by F. H. Taylor, not H. Priestly as stated by Malloch, and on the allotype and paratype labels the collector's name is printed "Priestley", and not "Priestly" as stated by Malloch.

Diagnosis: $D$. reversa can be distinguished from the other Australian species of the vicaria-group with entirely yellow pteropleural and prosternal setulae in the male sex by the complete but seam-like interfrontalia and the absence of $p v$ setae on hind femur (Text-fig. I5), and in the female sex by the weaker and less numerous av setae on hind femur (Text-fig. 21).

๙. Head: Eyes virtually bare, with only the usual microscopic pubescence. Ocellar setae quite strong, but not as long as anterior prst dc. Vertical setae short, only slightly longer than the adjacent post-ocular setulae. Post-ocular setulae very short, with several scattered setulae below the upper row. Parafrontalia, parafacialia and face silvery white pruinose; genae brown in ground-colour, brownish grey pruinose. Interfrontalia, viewed from below, with the visible parts grey pruinose. Parafrontalia slender, at lunula equal to twice diameter of anterior ocellus. I pair of inclinate ori above lunula, a weaker pair above, and 3-5 fine pairs, all on lower half of frons; in I $\hat{\sigma}$ (Yeppoon) connected by a few fine hair-like setulae to the pair of equally hair-like reclinate ors just before ocellar tubercle; sometimes a single auxiliary ors present. Antennae and basal half of arista yellow; 3rd segment white pruinose. 3rd segment three times as long as broad, in frontal view almost reaching epistoma. Arista with long regular plumosity, the longest of which slightly exceeds length of 3 rd antennal segment. Parafacialia slender, opposite insertion of arista equal to a little over diameter of anterior ocellus. Parafacialia and genae bare. In lateral view, vibrissal angle projecting slightly beyond profrons. Genae slender; the depth below lowest eye-margin equal to slightly less than width of 3 rd antennal segment. Peristomal setae rather dense, especially behind. Facial ridges with only I-2 short hairs above the usual cluster of setulae at vibrissal angle. Mentum of proboscis dark brown. Palpi dull yellow to brown; compressed, slender, weakly clavate toward tips. Thorax: Thorax and scutellum entirely yellow in ground-colour. Viewed from above and behind, mesonotum whitish dusted, more densely so before suture, with a pair of slender undusted paramedian vittae before suture mesad of the $d c$, continued a short distance behind suture, a pair of undusted prst patches between $p h$ and $d c$, and a pair of weakly dusted post vittae between $i a$ and $d c$. Scutellum whitish dusted, more densely so in basal lateral corners, thinly so in apical half. Pleura virtually undusted. Spiracles pale yellow. Mesonotum with the ground-setulae rather fine and erect, dense between the $d c$; black unless otherwise stated; pleural ground-setulae pale unless otherwise stated. $A c r o+I$, the single ( $p r s c)$ pair strong, much closer to each other than to the $d c$. All $d c$ setae strong. $2 h$, the outer one not much longer than the inner one. $2 p h$, the posterior one twice length of the anterior one. $2 i a$, the anterior one fine, sometimes vestigial or even absent. 2 sa, the posterior one weak. Post-alar callus with 2 setae. Post-alar declivity with a few scattered pale hairs. Supra-squamal ridge bare. Propleural depression bare. I propleural and I prostigmatal seta, each with a well-developed black auxiliary seta below; the former surrounded by few, the latter by numerous, setulae. Ist $n p l$ longer and stronger than 2nd; disc of notopleuron with a few 
setulae around the bases of both setae. Mesopleuron with 4 strong setae in caudal row, and a conspicuous black setula in upper anterior corner. Infra-alar bulla yellow, bare. Pteropleuron with the setulae on sub-alar ridge confined to anterior part, descending down to sternopleural and hypopleural margins. Stpl I +2 , the lower one weaker than anterior one and much closer to posterior one than to anterior one. Metathoracic spiracle moderate, subtriangular, with a few black setulae on lower margin. Squamopleuron with a number of fine pale hairs. Scutellum with a very strong apical and sub-basal lateral pair of setae. Disc with rather fine setulae, a few stronger ones apically. Legs: Yellow; fore and mid tarsal segments 3-5 brown, hind tarsal segments 4-5 brown, but tarsal colour rather variable and often all tarsi brownish. Tarsi unremarkable. Fore femur without $a v$ setae, with a complete row of $p v$ setae. Mid femur with I $a$ and $3 d-p$ preapical setae. Mid tibia with $2 p$ setae. Hind femur with the $a d$ row complete; I $d$ and I $p d$ preapical setae. Hind tibia with I strong $a d$ and I weaker $a v$ seta; some of the $p d$ ground-setulae more erect in apical half; $d$ preapical a little longer than tibial diameter, shorter than the ad. Wings: Weakly yellowish tinged, especially at base; the veins pale. Epaulet and basicosta yellow. Subcostal sclerite bare. Costa setulose ventrally as far as the apex of vein 2, the spine inconspicuous. Stem-vein bare above, with a few inconspicuous hairs below. Small cross-vein placed apicad of the point where vein I enters costa. Hind cross-vein oblique, strongly sinuate. Vein I bare. Vein 3 bare above; below with a few setulae on the node at base extending almost halfway to small cross-vein. Vein 4 inclined weakly forward towards vein 3 in apical section. Squamae and margins pale yellow, fringes pale. Knob of halteres yellow. Abdomen: Ground-colour yellow, tergites 4 and 5 with some brown discolouration. Sternites I-3 yellow, 4-5 brownish. In posterior view, tergites greyish white dusted, often with an inconspicuous narrow median vitta and the hind-margins undusted. Macrochaetae weaker and more decumbent than in fulvohivta: tergite 3 with some lateral marginals, tergite 4 with several lateral discals and a marginal row, tergite 5 with 2 discal and I marginal rows. Genitalia: Text-figs. 8o, 83, 86. Measurements: Length of body, 6.5-7.5 mm. Length of wing, 6.0-7.0 $\mathrm{mm}$.

ㅇ. Differs from the male as follows. Head: Eyes broadly separated; frons at middle less than an eye-width, broadening gradually to lunula. Upper inner eye-facets not enlarged. Ocellar setae strong, slightly longer than anterior prst $d c$ seta, directed forwards and slightly outwards. The incurved vti a little longer than the outcurved vte; pvt outcurved, two thirds length of vte. Parafrontalia silvery-white pruinose on lower half, otherwise grey pruinose, subshining black alongside ocellar tubercle. Interfrontalia black in ground-colour; viewed from below, grey pruinose with the frontal triangle tinged with brownish; frontal triangle otherwise visible as an ill-defined black streak extending half to two-thirds distance from anterior ocellus to lunula. Parafrontalia slender, broadening gradually towards lunula; at middle equal to almost twice diameter of anterior ocellus, at lunula broader than width of 3 rd antennal segment. Interfrontalia with the margins convex, broadest at middle of frons, at lunula slightly broader than a parafrontale, bare. 3-4 pairs of inclinate ori on lower three-fifths of frons, only the lowest pair really strong, with few interstitials; 2 pairs of reclinate ors, the lower pair half or less length of upper pair, upper pair closer to lower than to $v t i$; parafrontalia otherwise with short proclinate setulae on most of length. 3rd antennal segment infuscated beyond arista. Thorax: Viewed from above and behind, mesonotum and scutellum undusted except for a small median patch of white dust at neck. I ㅇ (Yeppoon) with 2 pairs of prsc acr setae. Notopleuron with the setulae fewer in number, often all dark. Vallar ridge sometimes bare. Hypopleuron sometimes bare below spiracle. Squamopleural hairs sometimes dark. Scutellum with o-3 setulae below the level of the strong setae. Legs: Mid femur without denser erect av and $p v$ ground-setulae in basal half, without $v$ setae except for $2-3$ short $p v$ setae. Hind femur without $p v$ setae. Wings : Vein 3 sometimes with a setula above on the node at base. Abdomen: In posterior view, tergites undusted, the dark areas with a matt appearance. Macrochaetae reduced and weak: tergites 4 and 5 with only weak lateral discal and marginal setae. Measurements: Length of body, 6.5$7.5 \mathrm{~mm}$. Length of wing, $6 \cdot 0-7 \cdot 0 \mathrm{~mm}$.

Material examined. Holotype + of reversa. Australia: north or north-west coast (J. Bynoe), BMNH. 
Holotype $\sigma^{t}$ of luteohirta. QueEnsland: Townsville (F. H. Taylor), SPHTM.

Torres Strait: Thursday Island, 7 ô, 5 우, I2.ii. Ig62 (D. B. Copeman), I $\sigma^{\wedge}$, I 우 BMNH, 6 ơ, 4 ㅇ CSIRO.

Queensland: Townsville, + allotype of luteohirta, 24.ii.rgr3 (H. Priestley), SPHTM; Townsville, ô paratype of luteohirta (H. Priestley), USNM; Townsville, I $\hat{\sigma}$, ii. I929 (Taylor), SPHTM; Townsville, I $\hat{o}(G . F$. Hill), SPHTM; Cairns, I $\hat{o}(F . H$. Taylor), SPHTM; Cairns, I ô, I.v.I955 (K. R. Norris \& I. F. B. Common), BMNH;

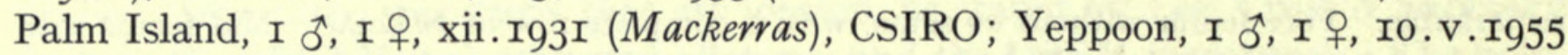
(K. R. Norris), ơ CSIRO, o BMNH; Carpentaria Downs Station, attracted to meat, 2 ㅇ, 8.v. I963, Qld. Dept. Pr. Ind.; 40 miles north of Cairns, I ㅇ, 6.iv. I965 (D. E. Havenstein), CSIRO.

Distribution and biology: Australia: Torres Strait (Thursday Island) and Queensland. An uncommon species.

This species has been collected in open country and has been attracted to meat. Life-history and immature stages unknown.

Variation: The male from Yeppoon has a few hair-like setulae connecting the ori and ors, but this space is bare in all other males, and the female from this locality has 2 pairs of prsc acr setae. One male from Thursday Is. lacks the anterior $i a$ on both sides, and several other specimens from this locality have this seta weak and only slightly differentiated from the adjacent ground-setulae. Some females, as in other species, lack the pale hairs on hypopleuron below spiracle. The colour of the basal tarsal segments varies from brown to yellow, but this may be due to differences in age of the specimens examined. Some of the specimens from Thursday Is. have darker hairs or setulae on certain parts, for example on notopleuron and squamopleuron, but this may be due to grease.

Affinities: D. reversa is most closely related to the Australian fulvohirta and flavohirta, from which it is scarcely distinguishable in the female sex (see above, p. 25I). The male differs from fulvohirta by the weaker femoral setae. It differs from vicaria, which it otherwise resembles, by the entirely yellow pteropleural setulae and in addition by the distinct interfrontalia in the male and the spot of white dust on the mesonotum at neck in the female.

\section{Females of Dichaetomyia flavohirta Malloch and reversa (Walker)}

As discussed above, females of these two species cannot always be separated. The following females have been studied and are tentatively identified:

\section{D. ? flavohirta Malloch}

Torres Strait: Badu Island, 2 ㅇ, 3.ii.rg62 (D. W. Lavers), BMNH and CSIRO.

Northern TERritory: East Point, Darwin, I ㅇ, I2.vi.Ig64 (K. R. Norris), CSIRO; Darwin, I +, I8.ix.I92I (W. K. Hunt), S.A. Mus. 


\section{D. ? reversa (Walker)}

QueEnsland: I2 miles S.E. of Bowen, I +, 6.v. I955 (K. R. Norris), CSIRO; Tolga, I + , 23. viii. I95I (A. H. Wetherly), CSIRO; Townsville, 2 ㅇ (F. P. Dodd), BMNH.

\section{Dichaetomyia fulvohirta sp. $\mathrm{n}$.}

$$
\text { (Text-figs. I6, I9, 8I, 84, 87) }
$$

Diagnosis: D. fulvohirta can be distinguished from the other Australian species of the vicaria-group with entirely yellow pteropleural and prosternal setulae by the long $a v$ and $p v$ setae on hind femur (Text-figs. I6 and I9); the long pv setae on mid femur and the complete but seam-like interfrontalia are useful supporting characters. The female is not known at present.

o. Head: Eyes virtually bare, with only the usual microscopic pubescence. Ocellar setae quite strong, but not as long as anterior prst $d c$. Vertical setae short, only slightly longer than the adjacent post-ocular setulae. Post-ocular setulae very short, with several scattered setulae below the upper row. Parafrontalia, parafacialia and face silvery white pruinose; genae reddish in ground-colour, brownish grey pruinose. Interfrontalia, viewed from below, with the visible parts grey pruinose. Parafrontalia slender, at lunula equal to twice diameter of anterior ocellus. 6 pairs of inclinate ori on lower half of frons, only the lowest pair really strong, the upper ones more hair-like; I pair of hair-like reclinate ors just before ocellar tubercle. Antennae and basal half of arista yellow; 3rd segment white pruinose. 3rd segment three times as long as broad, in frontal view almost reaching epistoma. Arista with long regular plumosity, the longest of which equals length of 3 rd antennal segment. Parafacialia and genae bare. In lateral view, vibrissal angle projecting slightly beyond profrons. Genae slender; the depth below lowest eye-margin equal to slightly less than width of 3 rd antennal segment. Peristomal setae rather dense, especially behind. Facial ridges with only $\mathrm{I}-2$ short hairs above the usual cluster of setulae at vibrissal angle. Mentum of proboscis dark brown. Palpi brownish; compressed, slender, weakly clavate towards tips. Thorax: Thorax and scutellum entirely yellow in ground-colour. Viewed from above and behind, mesonotum whitish dusted, more densely so before suture, with a pair of slender undusted paramedian vittae before suture mesad of the $d c$, continued a short distance behind suture, a pair of undusted prst patches between $p h$ and $d c$, and a pair of weakly dusted post vittae between $i a$ and $d c$. Scutellum thinly dusted, more densely so in basal lateral corners, undusted in apical half. Pleura virtually undusted. Spiracles pale yellow. Mesonotum with the ground-setulae rather fine and erect, dense between the $d c$, black unless otherwise stated; pleural ground-setulae pale unless otherwise stated. $A c r o+2$, the prsc pair strong, closer to each other than to the $d c$; preceded by a weaker but strong pair, but this character is so unusual in Dichaetomyia that it must be an aberrant feature. All $d c$ setae strong. $2 h$, the outer one not much longer than the inner one, with a weak 3 rd (inner) seta. $2 p h$, the posterior one one and a half times length of the anterior one. $2 \mathrm{ia}$, the anterior one fine. $2 \mathrm{sa}$, the posterior one weak. Post-alar callus with 2 setae. Post-alar declivity with a few scattered pale hairs. Suprasquamal ridge bare. Propleural depression bare. I propleural and I prostigmatal seta, each with a well-developed black auxiliary seta below; the former surrounded by few, the latter by numerous, setulae. Ist $n p l$ longer and stronger than 2nd; disc of notopleuron with several setulae around the bases of both setae. Mesopleuron with 4 strong setae in caudal row, and a conspicuous black setula in upper anterior corner. Infra-alar bulla yellow, bare. Pteropleuron with the setulae on sub-alar ridge confined to anterior part, descending down to sternopleural and hypopleural margins. Stpl I +2 , the lower one weaker than anterior one and much closer to posterior one than to anterior one. Metathoracic spiracle moderate, subtriangular, with a few black setulae on lower margin. Squamopleuron with a number of fine pale hairs. Scutellum with a very strong apical and sub-basal lateral pair of setae. Disc with rather fine setulae, a few 
stronger ones apically. Legs: Yellow, tarsal segments 3-5 brown. Tarsi unremarkable. Fore femur without $a v$ setae, with a complete row of $p v$ setae. Mid femur with the $a v$ ground-setulae more dense and erect in basal third; I $a$ and 3-4 $d-p$ preapical setae. Mid tibia with $2 p$ setae. Hind femur with the $a d$ row complete; I $-2 d$ and I $p d$ preapical setae. Hind tibia with I strong $a d$ seta and I-2 weaker $a v$ setae; some of the $p d$ ground-setulae more erect in apical half; $d$ preapical a little longer than tibial diameter, shorter than the $a d$. Wings: Rather yellowish at base, otherwise clear; the veins brownish. Epaulet and basicosta yellow. Subcostal sclerite bare. Costa setulose ventrally as far as the apex of vein 2, the spine inconspicuous. Stem-vein bare above, with a few pale hairs below. Small cross-vein placed below the point where vein I enters costa. Hind cross-vein oblique, strongly sinuate. Vein I bare. Vein 3 bare above; below with a few setulae on the node at base and just beyond. Vein 4 inclined weakly forward towards vein 3 in apical section. Squamae and margins pale yellow, fringes pale. Knob of halteres yellow. Abdomen: Rather shrivelled and discoloured by post-mortem decay. Tergites $\mathrm{I}+2$ and 3 brownish yellow, tergites 4 and 5 brown, sternites obscured; when cleared, ground-colour of tergites and sternites yellow, tergite 4 with a pair of small indistinct brown spots on hind margin, tergite 5 broadly brown on over median third of disc from fore- to hind-margin. In posterior view, tergites with some whitish dust. Macrochaetae quite strong and erect: tergite 3 with some lateral marginals, tergite 4 with several lateral discals and a marginal row, tergite 5 with 2 discal and I marginal row. Genitalia: Text-figs. 8I, 84, 87. Measurements: Length of body, $6 \cdot 0 \mathrm{~mm}$. Length of wing, $5.5 \mathrm{~mm}$.

Holotype §ิ. Queensland: Cannonvale, near Prosperpine, 24.vi.r958 (T. G. Campbell), CSIRO.

Distribution and biology: Australian: known only from the holotype, from Queensland, which was collected in or near rain forest. Life-history and immature stages unknown.

Variation: The presence of 2 pairs of prsc acr setae is clearly aberrant, and only a single pair (the present posterior pair) should be expected in further specimens.

Affinities: D. fulvohirta is most closely related to reversa and flavohirta. From flavohirta it may be distinguished by the absence of conspicuously enlarged eye-facets, broader frons, and stronger $p v$ setae on mid femur. From reversa it may be distinguished by the stronger and more numerous ventral setae on hind femur (cf. Text-figs. I5-I6 and I8-I9). It resembles australis in general habitus, but differs by the broader frons, richer hind femoral setation (cf. Text-figs. 8, Io, I6 and I9), and entirely yellow pteropleural setulae.

\section{THE POLITA-GRouP}

This group includes nine described Oriental and Australasian species in which there are 3 post $d c$ setae, fore tibia with a submedian $p$ seta, squamopleuron bare, and scutellum with 6-Io setulae descending in $\mathrm{I}-2$ irregular rows just below the level of the strong setae, otherwise bare laterally and ventrally.

The polita-group possesses the following additional characters:

Mentum of proboscis dusted. Male with 2 pairs of reclinate ors. Female with only one pair of strong inclinate ori at lunula, with a second weak pair above them; parafrontalia comparatively broad (Text-fig. 22). 2 prst $d c$ setae, the anterior pair at most half as long as the posterior pair, sometimes absent. Prst acr setulae 9- to ro-serial. Pra seta well-developed but short, about half length of and $n p l$. Vallar ridge bare. Hypopleuron bare on beret and below spiracle, with some hairs on metepisternum. Stem-vein bare above, rarely individually with a few fine hairs at base. Lower squama bare on disc. 
Six Malayan and Philippine species belong to this group: atratula Malloch, fulvitarsis Malloch, fusciventris Emden, indica (Walker), nigrita Malloch and nigriventris Malloch. The New Guinea polita (Stein) and nigrolineata (Stein) also belong here. I have seen further undescribed Melanesian species and subspecies related to polita. D. collessi sp. n. differs from all these species by the entirely yellow colour of thorax and legs.

\section{Dichaetomyia collessi sp. $\mathrm{n}$.}

$$
\text { (Text-figs. 22, 70, 73, 76) }
$$

Diagnosis: D. collessi can be distinguished from all other Australian species with bare scutellar margins and 3 post $d c$ setae by the bare squamopleuron and the presence of a $p$ seta on fore tibia.

๙. Head: Frons slender, at narrowest point eyes separated by diameter of anterior ocellus or slightly more. Eyes virtually bare, with only the usual microscopic pubescence; upper inner facets enlarged as usual but not conspicuously so. Ocellar setae fine, not as long as anterior prst $d c$. Vertical setae short, only slightly longer than the adjacent post-ocular setulae. Postocular setulae very short, with several scattered setulae below the upper row which are entirely black. Parafrontalia and parafacialia silvery white pruinose, the former grey on upper third; face thinly white pruinose; genae black in ground-colour, brownish grey pruinose. Interfrontalia, viewed from below, with the visible parts grey pruinose. Parafrontalia slender, at lunula equal to just over diameter of anterior ocellus. Interfrontalia extremely slender, two small triangles visible before ocellar tubercle and at lunula, present as a line on median third of frons. 3 pairs of quite strong inclinate ori with a fine hair-like pair above them, sometimes with a few hair-like interstitials, all on lower half of frons; ori sometimes connected to ors by a few fine setulae. First two antennal segments and base of 3 rd segment yellow, 3rd segment whitish pruinose; arista dull yellow on basal third. 3rd segment three times as long as broad, in frontal view almost reaching epistoma. Arista with long regular plumosity, the longest of which almost equals length of 3 rd antennal segment. Parafacialia slender, opposite insertion of arista equal to under diameter of anterior ocellus. Parafacialia and genae bare. In lateral view, parafrontalia and parafacialia largely invisible; vibrissal angle projecting slightly beyond profrons. Genae slender; the depth below lowest eye-margin equal to slightly less than width of 3 rd antennal segment. Peristomal setae rather dense, especially behind. Facial ridges with short hairs ascending to midway level of 3 rd antennal segment. Mentum of proboscis dark brown. Palpi compressed, weakly clavate towards tips. Thorax: Thorax and scutellum entirely yellow in ground-colour. Viewed from above and behind, mesonotum rather densely whitish dusted before suture, with a pair of slender undusted paramedian vittae, mesad of the $d c$, and a pair of undusted triangular marks between $d c$ and $p h$; indistinctly and thinly dusted behind suture, in extreme posterior view usually with undusted vittae between $d c$ and $i a$ and between $i a$ and $s a$, and with a broad undusted prsc fascia. Pleura undusted. Spiracles pale yellow to yellow. Mesonotum with the ground-setulae rather sparse and fine, except between the $d c$; all thoracic ground-setulae black unless otherwise stated. $A c r$ o $+\mathrm{I}$, the single (prsc) pair quite strong, placed behind the transverse level of prsc $d c$ and placed closer to each other than to the $d c$. $2 h$, the outer one one and a half times length of the inner one. $2 p h$, the posterior one twice length of the anterior one. $2 i a$, the anterior one often weak, two to three times as long as a ground-setula. $2 s a$, the posterior one weak. Post-alar callus with 2 setae, with setulae present on the ridge between inner seta and scutellum. Post-alar declivity with a few scattered pale and dark hairs. Supra-squamal ridge bare, sometimes with a few fine pale or dark hairs. Prosternum black setulose, sometimes some setulae appearing pale. Propleural depression bare. I propleural and I prostigmatal seta, the latter with a well-developed auxiliary seta below; the former surrounded by few, the latter by numerous, dark setulae. Ist $n p l$ longer and stronger than 2nd; 
disc of notopleuron with several dark setulae around the bases of both setae. Mesopleuron with 4 strong setae in caudal row, and a conspicuous black setula in upper anterior corner; groundsetulae black. Infra-alar bulla yellow, bare. Pteropleuron with the setulae all black, those on sub-alar ridge confined to anterior part, descending down to sternopleural and hypopleural margins. Stpl I +2 , the lower one weaker than anterior one and slightly closer to posterior one than to anterior one. Hypopleuron with the hairs on metepisternum dark. Metathoracic spiracle quite large, subtriangular, with a row of quite long dense setulae along lower and posterior margins. Scutellum with a very strong apical and sub-basal lateral pair of setae. Disc with rather short dense setulae, a few stronger ones apically. Legs: Yellow, apical tarsal segments darker; I ô (Bamaga) with femora darkened in basal half or more. Tarsi unremarkable. Fore femur with a complete row of $p v$ setae. Mid femur without av setae, on $p v$ surface with a row of setae in basal half that equal femoral depth that merge into the ground-setulae in apical half, but sometimes only poorly developed; I $a$ and $3(-4) d-p$ preapical setae. Mid tibia with $2 p$ setae. Hind femur with a complete row of $a v$ setae, those in basal half rather fine and sometimes poorly developed, the preapical 3 strong; on $p v$ surface with a row of short fine erect setae in basal half. about half femoral depth, these sometimes reduced and only I-2 short setulae evident; ad row complete; I $d$ and I $p d$ preapical setae. Hind tibia with I $a d$ and 2 ( 3 on one side in holotype) $a v$ setae; some of the $p d$ ground-setulae more erect in apical half, with a stronger one level with the $a d ; d$ preapical subequal to tibial depth, shorter than the $a d$. Wings: Rather yellow costally and basally, otherwise usually faintly but conspicuously smoky. Epaulet and basicosta yellow. Subcostal sclerite bare. Costa setulose ventrally as far as the apex of vein 2, the spine inconspicuous. Stem-vein bare above, in basal half below with a number of quite long fine dark hairs. Small cross-vein placed basad of or below the point where vein I enters costa. Hind cross-vein oblique. Vein I bare. Vein 3 bare above; below with a few setulae on the node at base and just beyond. Vein 4 inclined weakly forward towards vein 3 in apical section. Squamae deep yellow, margins and fringes paler. Knob of halteres weakly infuscated. Abdomen: Tergite $\mathrm{I}+2$ yellow; tergite 3 yellow with a dark hind-marginal fascia, usually occupying posterior three-quarters of tergite, rarely narrow; tergite 4 dark except for anterior lateral angles or a slender fore-marginal fascia, sometimes wholly dark; tergite 5 dark with a yellow hind-margin. Sternites yellow, sternite 5 darkened towards lobes or entirely dark. In posterior view, tergites thinly grey to brownish grey dusted, without an undusted median vitta. Macrochaetae quite well-developed: tergites 4 and 5 each with a marginal row, and tergite 5 also with a discal row interrupted at middle. Sternite I dark setulose. Genitalia: Text-figs. 70, 73, 76. Measurements: Length of body, $6{ }^{\cdot} 5^{-7} 7^{\circ} \mathrm{o} \mathrm{mm}$. Length of wing, $6{ }^{\circ} \mathrm{o}-6 \cdot 5 \mathrm{~mm}$.

․ Differs from the male as follows. Head: Eyes broadly separated; frons at middle less than an eye-width, broadening gradually to lunula. Upper inner eye-facets not enlarged. Ocellar setae strong, slightly shorter than end prst $d c$ seta, directed forwards and slightly outwards. Vti strong, incurved, longer than the outcurved vte; vte twice as long as post-ocular setulae; pvt weak, outcurved. Parafrontalia silvery white pruinose on lower quarter only, otherwise dull grey pruinose, subshining black alongside ocellar tubercle. Interfrontalia black in ground-colour, sometimes dull red towards lunula; viewed from below, brownish grey pruinose; frontal triangle visible as an ill-defined black streak extending two-thirds to three-quarters distance from anterior ocellus to lunula. Parafrontalia broadening gradually towards lunula; at lunula a parafrontale broader than width of 3 rd antennal segment. Interfrontalia with the margins broadly convex, weakly indented around middle, at lunula slightly broader than a parafrontale, bare. 2 pairs of reclinate ors, the upper pair strongest and placed closer to lower pair than to $v t i$; parafrontalia otherwise with short proclinate setulae from upper ors to lunula. Parafacialia slightly broader, opposite insertion of arista just over diameter of anterior ocellus. Thorax: Scutellum undusted. Legs: Mid femur with the $p v$ setae usually absent. Hind femur with the $a v$ and $p v$ setae in basal half weaker, sometimes absent. Wings: Knob of halteres yellow or dark. Abdomen: Ground-colour varying as in male, sometimes almost entirely yellow; generally lighter than in male. In posterior view, without conspicuous dust, appearing subshining. Macrochaetae fewer in number and weaker. Measurements: Length of body, 6.5$7^{\circ} \mathrm{omm}$. Length of wing, $6 \cdot 0-6{ }^{\circ} \mathrm{mm}$. 
Holotype ơ. Queensland: Mossman Gorge, 24.iv.rg67 (D. H. Colless), CSIRO.

Paratypes, $9 \hat{\jmath}, 9$ ㅇ. QueEnsland: Mossman Gorge, I + , 2I.iv.rg67, I $\widehat{0}$, 23.iv. I967, and I + , 24.iv. I967 (D. H. Colless), I ô, I 9 BMNH, I 9 CSIRO; Bamaga, Cape York, I ô, 26.iii. I964, and I ô, 4.iv.Ig64 (I. F. B. Common \& M.S. Upton), CSIRO; 4 miles E. of El Arish, I ô, I.v. I958 (T. G. Campbell), CSIRO; Mt. Bartle Frere, East base, 80 ft., I ô, 25.iv. I955 (K. R. Norris \& I. F. B. Common), CSIRO; Bamboo Creek, near Miallo, N. of Mossman, 2 ô, I + , 25.iv. Ig67 (D. H. Colless), I ô BMNH, I ô, I o CSIRO; Innisfail, I ô (F. H. Taylor), SPHTM; Crystal Cascades, Cairns, 2 ㅇ, r9.iv. I967 (D. H. Colless), CSIRO; The Boulders, Babinda, I $q$, ro.v.rg67 (D. H. Colless), CSIRO; Kuranda, I ㅇ, I7.v.I958 (D. K. McAlpine), Aust. Mus.; Claudie River near Mt. Lamond, 2 +, I and 5.vi.Ig66 (D. K. McAlpine), Aust. Mus.; Mt. Spec, I đ, I.iv. I965 (D. E. Havenstein), CSIRO.

Distribution and biology: Australia: Queensland. An uncommon species.

This species has been found exclusively in lowland rain forest, occurring up to $300 \mathrm{~m}$. Life-history and immature stages unknown.

Variation: This species is rather constant in structure and colour, but there is some variation in mid and hind femoral chaetotaxy that makes it difficult to use these characters in separating collessi from aseta. In the male, the mid femur has the pv setae well developed in seven out of nine specimens; the hind femur has the av row poorly developed in basal half in two out of nine specimens, and the $p v$ setae limited to only $\mathrm{I}-3$ weak setae in three out of nine specimens. In the female sex, the mid femur has the $p v$ setae well developed in only two out of nine specimens; the hind femur has the $a v$ row poorly developed in basal half in five out of nine specimens, and the $p v$ setae limited to only I-3 weak setae in five out of nine specimens and none at all in one out of nine. In the female the dusted $a c r$ vitta is sometimes confined to the neck.

Affinities: D. collessi occupies a rather isolated position amongst Australian Dichaetomyia. It is most closely related to the New Guinea polita (Stein) and, more distantly, to the Malayan and Philippine species of the polita-group. From all of these it can be distinguished by its entirely yellow thorax and legs.

Discussion: One of the specimens named as apicalis (Stein) by Malloch, but not recorded by Malloch, belongs to this species.

\section{THE DEMENS-GROUP}

This small group includes five described species, all of which are confined to the Australasian region, in which there are 3 post $d c$ setae, fore tibia without a submedian $p$ seta, squamopleuron bare, and scutellum with only a few (2-5) setulae at or just below the level of the strong setae, otherwise bare laterally and ventrally.

The demens-group possesses the following additional characters:

Mentum of proboscis dusted. Male with I pair of reclinate ors. Female parafrontalia normal, narrow (Text-fig. 23). 2 post $d c$ setae, the anterior pair at most half as long as the posterior pair. Prst acr setulae 8- to Io-serial. Pra seta well-developed but short, about half length of 2nd $n p l$. Vallar ridge bare. Hypopleuron bare on beret and below spiracle, with some hairs on metepisternum. Stem-vein bare above, rarely individually with a few fine hairs at base. Lower squama bare on disc. 
Three of the non-Australian species of this group, bifasciata (Stein) from New Guinea, leucoceros (Walker) from Misoöl Island, and demens (Stein) from Waigeo Island, differ from aseta by the extensively or partially infuscated mesonotum and pleura. The fourth species, carolina Snyder from the Eastern Caroline Islands, differs from aseta by the entirely fulvous abdomen, without dark bands.

\section{Dichaetomyia aseta sp. n.}

\section{(Text-figs. 23, 88, 9I, 94)}

Diagnosis: D. aseta can be distinguished from all other Australian species with bare scutellar margins and 3 post $d c$ setae by the bare squamopleuron and the absence of a $p$ seta on fore tibia.

ô. Head: Frons slender, at narrowest point eyes separated by diameter of anterior ocellus. Eyes virtually bare, with only the usual microscopic pubescence; upper inner facets enlarged as usual but not conspicuously so. Ocellar setae fine, subequal to anterior prst $d c$. Vertical setae short, only slightly longer than the adjacent post-ocular setulae. Post-ocular setulae very short, with several scattered setulae below the upper row which are entirely black. Parafrontalia and parafacialia silvery white pruinose, the former greyer towards vertex; face thinly white pruinose; genae black in ground-colour, grey to brownish grey pruinose. Interfrontalia, viewed from below, with the visible parts grey pruinose. Parafrontalia slender, at lunula equal to just over diameter of anterior ocellus. Interfrontalia reduced, two small triangles visible before ocellar tubercle and at lunula, present as a line or almost obsolete on median third of frons. 2 pairs of moderate inclinate ori, with o-I pairs of interstitials and a fine hair-like pair above them, all on lower third of frons. First 2 antennal segments and basal third of arista yellow; 3rd segment white pruinose. 3rd segment two and a half to three times as long as broad, in frontal view fallling short of epistoma by almost half its own width. Arista with long regular plumosity, the longest of which exceeds length of 3rd antennal segment. Parafacialia slender, opposite insertion of arista equal to diameter of anterior ocellus. Parafacialia and genae bare. In lateral view, parafrontalia and parafacialia largely invisible; vibrissal angle projecting slightly beyond profrons. Genae slender; the depth below lowest eye-margin equal to less than width of 3 rd antennal segment. Peristomal setae rather dense, especially behind. Facial ridges with short hairs ascending only a short distance above level of tip of 3rd antennal segment. Mentum of proboscis brown. Palpi compressed, weakly clavate towards tips. Thorax: Thorax and scutellum entirely yellow in ground-colour. Viewed from above and behind, mesonotum thinly whitish dusted: before suture with a pair of undusted or thinly dusted paramedian vittae, mesad of $d c$, and a pair of undusted patches between $d c$ and $p h$; more thinly dusted behind suture, with undusted vittae between $d c$ and $i a$ and between $i a$ and $s a$, virtually undusted medially between the $d c$, and with an undusted prsc fascia. Pleura undusted. Spiracles pale yellow. Mesonotum with the ground-setulae sparse and fine, except between the $d c$; all thoracic ground-setulae black unless otherwise stated. $A c r \mathrm{O}+\mathrm{I}$, the single $(p r s c)$ pair quite strong, placed behind the transverse level of prsc $d c$, equidistant from $d c$ or closer to each other than to the $d c .2 h$, the anterior one one and a half times length of the inner one. 2 ph, the posterior one twice length of the anterior one. $2 \mathrm{ia}$, the anterior one weak. $2 s a$, the posterior one weak. Post-alar callus with 2 setae, with setulae present on the ridge between inner seta and scutellum. Post-alar declivity with a few scattered pale and dark hairs. Supra-squamal ridge bare. Prosternum densely brown setulose, several of the setulae appearing golden, sometimes pale setulose. Propleural depression bare. I propleural and I prostigmatal seta, the latter with a well-developed auxiliary seta below; the former surrounded by few, the latter by numerous, mainly dark setulae. Ist $n p l$ longer and stronger than 2nd; disc of notopleuron with several dark setulae around the bases of both setae. Mesopleuron with 4 strong setae in caudal row, and a conspicuous setula in upper anterior corner; ground-setulae entirely dark. Infra-alar bulla yellow, bare. Pteropleuron with 
the setulae all dark, those on sub-alar ridge confined to anterior part, descending down to sternopleural and hypopleural margins. Stpl I +2 , the lower one subequal to or slightly weaker than anterior one and much closer to posterior one than to anterior one. Hypopleuron with brown hairs on metepisternum. Metathoracic spiracle quite large, subtriangular, with a row of quite long dense setulae along lower and posterior margins. Scutellum with a very strong apical and sub-basal lateral pair of setae. Disc with rather short dense setulae, a few stronger ones apically and laterally. Legs: Yellow, apical tarsal segments brown. Tarsi unremarkable. Fore femur with a complete row of $p v$ setae. Mid femur without $a v$ setae, on $p v$ surface with a row of setae in basal half that equal femoral depth and that merge into the ground-setulae in apical half, sometimes reduced to I-2 setae; I $a$ and $3 d-p$ preapical setae. Mid tibia with $2 p$ setae. Hind femur with a complete row of $a v$ setae, those in basal half rather fine, the preapical 3 strong; without or with a few short $p v$ setae, in basal quarter; $a d$ row complete; I $d$ and I $p d$ preapical setae. Hind tibia with I $a d$ and $2 a v$ setae; some of the $p d$ ground-setulae more erect in apical half, with a stronger one near level of the $a d ; d$ preapical subequal to tibial depth, slightly shorter than the $a d$. Wings: Rather yellow costally and basally, otherwise faintly but conspicuously smoky. Epaulet and basicosta yellow. Subcostal sclerite bare. Costa setulose ventrally as far as the apex of vein 2, the spine inconspicuous. Stem-vein bare above, in basal half below with a few short brown hairs. Small cross-vein placed below the point where vein I enters costa. Hind crossvein oblique. Vein I bare above. Vein 3 bare above; below with a few setulae on the node at base extending halfway to small cross-vein. Vein 4 inclined weakly forward towards vein 3 in apical section. Squamae deep yellow, sometimes brownish posteriorly, margins and fringes paler. Knob of halteres weakly infuscated. Abdomen: Tergite $\mathrm{I}+2$ yellow, sometimes with a darker hind-margin; tergite 3 yellow, slightly to broadly darkened on hind-margin, browner laterally; tergite 4 with a broad dark fascia, browner laterally, fore- and sometimes hind-margins yellow, or entirely brown. Sternites yellow, posterior ones often infuscated. In posterior view, tergites subshining. Macrochaetae quite well developed: tergite 4 with some lateral discals and a marginal row that is interrupted at middle, tergite 5 with some lateral discals and a marginal row. Sternite I brown setulose. Genitalia: Text-figs. 88, 9I, 94. Measurements: Length of body, $6 \cdot 5-7 \cdot 0 \mathrm{~mm}$. Length of wing, $6 \cdot 0-6 \cdot 5 \mathrm{~mm}$.

․ Differs from the male as follows. Head: Eyes broadly separated; frons at middle less than an eye-width, broadening gradually to lunula. Upper inner eye-facets not enlarged. Ocellar setae strong, slightly shorter than 2 nd prst $d c$ seta, directed forwards and slightly outwards. Vti strong, incurved, longer than the outcurved vte; vte twice as long as post-ocular setulae; pvt weak, outcurved. Parafrontalia silvery white pruinose on lower third to half, otherwise dull grey pruinose, shining black alongside ocellar tubercle. Interfrontalia black in ground-colour; viewed from below, brownish grey pruinose; frontal triangle visible as a subshining black streak extending three-quarters distance from anterior ocellus to lunula. Parafrontalia broadening towards lunula; at lunula a parafrontale broader than width of 3 rd antennal segment. Interfrontalia with the margins convex, broadest at middle of frons, at lunula broader than a parafrontale, bare. 2 pairs of moderate reclinate ors, the upper one strongest and placed closer to lower pair than to $v t i$; parafrontalia otherwise with short proclinate setulae from upper ors to lunula. 3rd antennal segment infuscated beyond arista. Parafacialia broader, opposite insertion of arista just over diameter of anterior ocellus. Palpi darkened at base. Thovax: Scutellum undusted. Legs : Mid femur with the $p v$ setae reduced, often only I seta. Hind femur with the $p v$ setulae few and weak, as in male. Wings: Squamae and halteres sometimes rather lighter. Abdomen: Varying as in male; basic pattern as in male, but reduced and colour generally lighter. Macrochaetae reduced: tergite 5 with only a few lateral discals and a weak marginal row. Measurements: Length of body, $6 \cdot 5-7 \cdot 0 \mathrm{~mm}$. Length of wing, $6 \cdot 0-6 \cdot 5 \mathrm{~mm}$.

Holotype $\delta^{\star}$. QueEnsland: Upper Mulgrave River, Io m. Goldsborough Road, 9.v.Ig67 (D. H. Colless), CSIRO.

Paratypes, I9 $\hat{0}$, 3I ㅇ. QueEnsland: Upper Mulgrave River, 8 miles Goldsborough Road, I ô, 9.v.Ig67 (D. H. Colless), BMNH; Upper Mulgrave River, Io miles 
Goldsborough Road, I , 9.v.rg67 (D. H. Colless), CSIRO; Io miles S. of Daintree, I ô, 29.iv. I955 (K. R. Norris), CSIRO; The Boulders, Babinda, 4 ô, 6 o, ro.v. I967 (D. H. Colless), I ô, 2 우 BMNH, 3 ô, 4 우 CSIRO; Mossman Gorge, I ô, 2 우, 23.iv. Ig67 (D. H. Colless), I + BMNH, I ô, I o CSIRO; Mossman Gorge, I ô, I ㅇ, 24.iv. I 967 (D. H. Colless), ô BMNH, ㅇ CSIRO; Mt. Edith Forest Road, I mile off Danbulla Road, I ô, I + , 6.v. I967 (D. H. Colless), CSIRO; Mt. Edith Forest Road, I $\frac{1}{2}$ miles off Danbulla Road, 2 +, $6 . v \cdot I 967$ (D. H. Colless), BMNH \& CSIRO; Wongabel State Forest, I ô, 5.v.I967 and I ô, 7.v.I967 (D. H. Colless), CSIRO; Kuranda Range State Forest, 7-8 miles Black Mtn Road, I o, 20.iv.I967 (D. H. Colless), CSIRO;

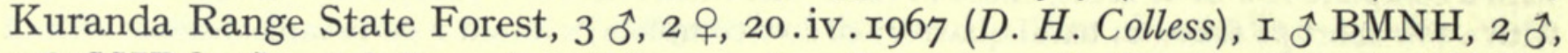
2 ㅇ CSIRO; Crystal Cascades, Cairns, I ô, I ㅇ, I9.iv. I967 (D. H. Colless), CSIRO; Mount Spec, I $9,26 . \mathrm{iv} .{ }_{958}$ (K. L. Harley), CSIRO; 3 miles N. of Kuranda, I + 24.iv. I955 (K. R. Norris), CSIRO; Mt. Bartle Frere, East base, $80 \mathrm{ft}$., I (K. R. Norris), CSIRO; Mount Spec, 2,60o ft., 2 ㅇ, 4.iii.I964 (I. F. B. Common \& M. S. Upton), CSIRO; I ô, I $q$ (Brunetti Coll.), BMNH; 2 q, ix. I9Io (Brunetti Coll.), BMNH; Kuranda, 2 ㅇ, 2I.v.I958, I ㅇ, I9.v.I958, I +, I7.v. I958, and I §ै, 6.v. I958 (D. K. McAlpine), Aust. Mus.; Claudie River near Mt. Lamond, I +, 28.v. I966 (D. K. McAlpine), Aust. Mus.; Kuranda, 2 ㅇ, II and I3.iii.I956 (J. L. Gressitt), Bishop; Mount Spec, I ô, I.iv.rg65 (D. E. Havenstein), CSIRO.

Distribution and biology: Australia: Queensland. An uncommon species.

This species has been found almost exclusively in rain forest, up to $850 \mathrm{~m}$., and also in riverine scrub in savannah woodland.

Life-history and immature stages unknown.

Variation: This species is rather constant in structure and colour, but some slight variation has been observed. The prosternal setulae are basically dark, but may sometimes be partially pale or even, in a few females, entirely pale. The palpi are usually entirely pale, but may be darkened towards base. The median mesonotal vitta in the female varies in extent: it may be confined to neck, or may reach to suture. The stem-vein in some individuals bears tiny pale hairs at base on upper wingsurface. Leg chaetotaxy varies slightly in both sexes. In the male, the $p v$ setae on mid femur vary from $\mathrm{I}-2$ to a short row in basal half; on hind femur the $a v$ row is complete though weak in basal half, and $p v$ surface has none to a few short setulae in basal half. In the female, the mid femur has only I $-3 p v$ setae; hind femur has only I-3 weak $p v$ setae, and the $a v$ row complete or almost absent in basal half.

Affinities: $D$. aseta is very closely related to the other species of the demens-group, from which it can be distinguished by the entirely yellow ground-setulae of mesonotum and pleura, and dark-banded abdomen. It is most closely related to carolina Snyder which has an entirely clear yellow unmarked abdomen. Like collessi sp. n., aseta occupies an isolated position amongst Australian Dichaetomyia.

\section{THE RUFESCENS-GROUP}

This group includes at least twelve Australasian and about forty-five Oriental species, in which the scutellum possesses no to several setulae descending just below 
the level of the strong setae, otherwise bare laterally and ventrally, 3 post $d c$ setae, fore tibia without a submedian $p$ seta, and squamopleuron haired.

The rufescens-group possesses the following additional characters:

Hypopleuron bare on beret, sometimes haired below spiracle, always haired on metepisternum. Pra seta well-developed but short, about half length of end $n p l$ seta. Stem-vein bare or haired above. 2 prst dc setae, the anterior one usually strong. Prst acr setulae 7- to ro-serial. Vallar ridge haired or bare. Lower squama bare on disc. Mentum of proboscis dusted.

A very large number of Oriental species belongs to this group which is clearly rather heterogeneous as defined at present. Species described or recorded from the Australasian region differ from the four Australian species as follows:

D. lombokensis Hennig, from Lombok Island, is a much darker species: mesonotum black except on humeri, scutellum infumated, infra-alar bulla dark.

$D$. incerta (Stein), from New Guinea, has the mesonotum largely darkened and, in the female, hind femur with 3 preapical $a v$ setae, otherwise without $a v$ or $p v$ setae.

D. latitarsis (Stein), from the Oriental region and New Guinea, is closest to spinuligera sp. n.: see the discussion under that species (p. 226).

D. rota Snyder, from the South Mariana Islands (Rota Is.), is known in the male sex only, and possesses a broad frons.

D. nigroscuta Bohart and Gressitt, from the South Mariana Islands (Guam Is.), has the legs entirely black, with only the knees yellow.

D. sabroskyi Snyder, from the West Carolina Islands (Palau Is.), has the scutellum black and the legs, including tibiae, entirely dark.

D. apicalis (Stein) and D. rufescens (Stein) are discussed below.

It is quite possible that rufescens will be found in Australia, for which reason a fuller discussion of its characters is given below, together with those of apicalis. Both species would be traced to couplet 2I in the key above (p. 209).

\section{Dichaetomyia spinuligera sp. $\mathrm{n}$.}

(Text-figs. 25, 27, 29, 39, 4I, 42, 89, 92, 95)

Diagnosis: D. spinuligera can be distinguished from all other Australian Dichaetomyia by the presence of $a v$ spinules on fore and mid femora in the male, and by the dilated 3 rd to $5^{\text {th }}$ fore tarsal segments and by the conspicuous pale setulae among the pile on supra-spiracular convexity in the female.

o. Head: Frons very slender, at narrowest point eyes separated by less than diameter of anterior ocellus. Eyes virtually bare, with only the usual microscopic pubescence; upper inner facets enlarged as usual but not conspicuously so. Ocellar setae fine, not as long as anterior prst dc. Vertical setae short, only slightly longer than the adjacent post-ocular setulae. Postocular setulae very short, with several scattered setulae below the upper row, which are black above but more golden below. Parafrontalia, parafacialia and face silvery white pruinose; genae black in ground-colour, grey pruinose. Interfrontalia, viewed from below, with the visible parts grey pruinose. Parafrontalia slender, at lunula equal to over diameter of anterior ocellus. Interfrontalia reduced, a small triangle visible at lunula and a longer one before ocellar tubercle, obsolete or visible as a faint seam on median half of frons. 3-4 pairs of weak inclinate ori, on less than lower third of frons; I pair of hair-like reclinate ors just before ocellar tubercle. Antennae and basal third of arista yellow; 3rd segment pale yellow, white pruinose. 3rd segment three times as long as broad, in frontal view almost reaching epistoma. Arista with long regular 
plumosity, the longest of which almost equals length of 3 rd antennal segment. Parafacialia slender, opposite insertion of arista equal to diameter or less of anterior ocellus. Parafacialia and genae bare. In lateral view, parafrontalia and parafacialia largely invisible; vibrissal angle projecting slightly beyond profrons. Genae slender; the depth below lowest eye-margin equal to less than width of 3 rd antennal segment. Peristomal setae rather dense, especially behind. Facial ridges with short hairs ascending to midway level of 3 rd antennal segment. Mentum of proboscis light brown. Palpi compressed, weakly clavate towards tips. Thorax: Thorax and scutellum entirely yellow in ground-colour. Viewed from above and behind, mesonotum with rather variable dust: either with very thin irregular white dust that is concentrated around suture and prst dc setae; or thinly white dusted with the usual undusted or thinly dusted markings: a pair of paramedian vittae mesad of the $d c$, a pair of prst patches between $p h$ and $d c$, and a pair of post vittae between $i a$ and $d c$. Scutellum undusted. Pleura virtually undusted. Anterior spiracle pale yellow. Mesonotum with the ground-setulae rather short and sparse, except between the $d c$; all thoracic ground-setulae black unless otherwise stated. $A c r o+\mathrm{I}$, the single (prsc) pair well developed, placed behind the transverse level of prsc $d c$ and closer to each other than to the $d c$; prst setulae irregularly 8-serial. $2 h$, the inner one not much shorter than, to two-thirds the length of, the outer one. 2 ph, the posterior one twice length of the anterior one. $2 \mathrm{ia}$, the anterior one fine or sometimes absent. $2 \mathrm{sa}$, the posterior one weak. Post-alar callus with 2 setae, with setulae present on the ridge between inner seta and scutellum. Post-alar declivity with a few golden hairs. Supra-squamal ridge bare. Propleural depression bare. I propleural and I prostigmatal seta, the latter with a well-developed auxiliary seta below; the former surrounded by few, the latter by numerous, mainly golden setulae. Ist $n p l$ longer and stronger than 2nd; disc of notopleuron with a few pale or pale and dark setulae around the bases of both setae. Mesopleuron with 4 strong setae in caudal row, and a conspicuous dark setula in upper anterior corner; ground-setulae mainly golden. Infra-alar bulla yellow, bare. Pteropleuron with the setulae mainly black, tips of lower ones pale; those on sub-alar ridge confined to anterior part, descending down to sternopleural and hypopleural margins. Vallar ridge bare. Stpl I +2 , the lower one subequal to anterior one and slightly closer to posterior one than to anterior one. Hypopleuron bare below spiracle; with some pale hairs on metepisternum. Metathoracic spiracle quite large, subtriangular, with a row of quite long setulae along lower and
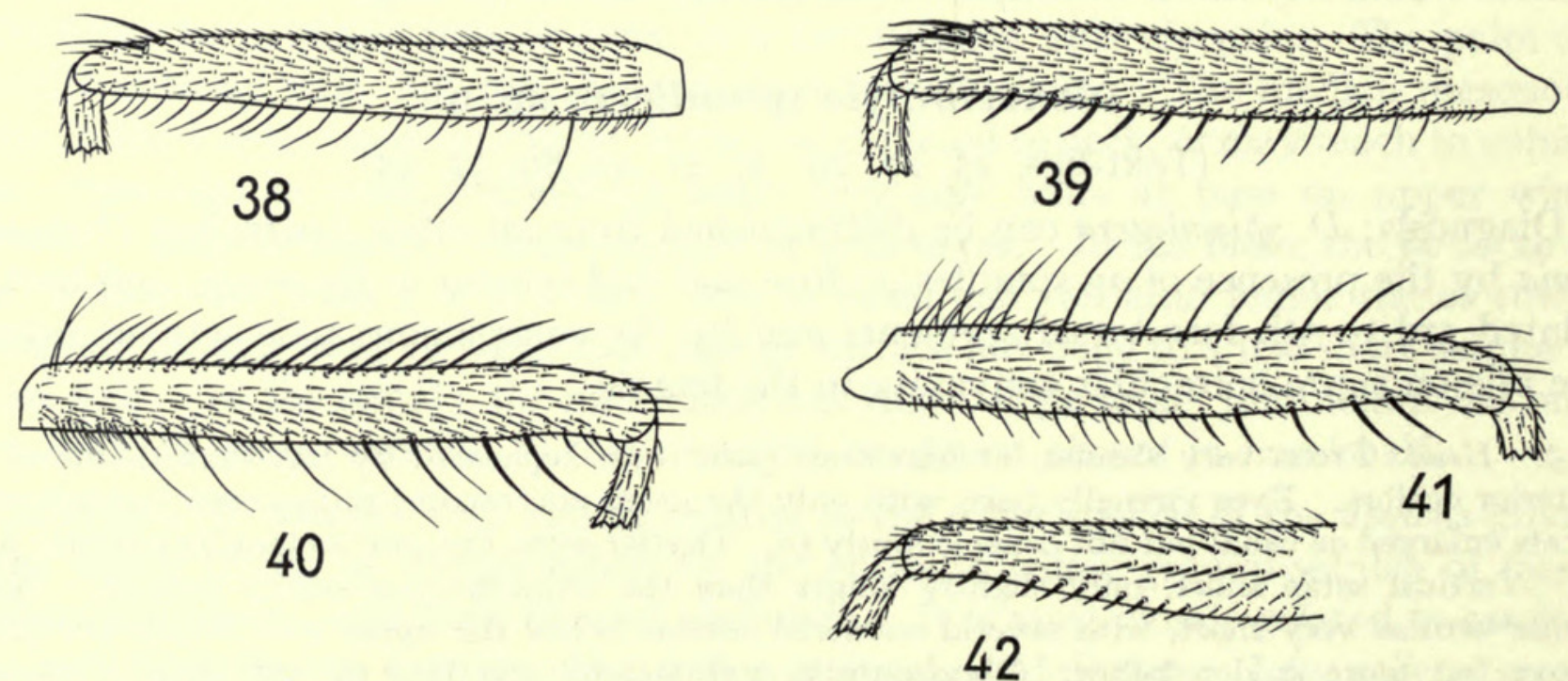

FIGs. 38-42. of femora of the Dichaetomyia rufescens group: 38, D. fusconota sp. n., hind femur, posterior view (Q, Kuranda, ix. Io, paratype); 39, D. spinuligera sp. n., hind femur, posterior view (Q, Bamboo Ck, 25.iv.67, paratype); 40, D. fusconota, hind femur, anterior view; 4I, D. spinuligera, hind femur, anterior view; 42, D. spinuligera, fore femur, anterior view. 
posterior margins. Scutellum with a very strong apical and sub-basal lateral pair of setae. Disc with rather short dense setulae, a few stronger ones apically. Legs: Yellow, apical tarsal segments darker. Tarsi unremarkable. Fore femur with a row of short stout av spinules in apical half (Text-fig. 42); with a complete row of $p v$ setae. Mid femur with a row of short stout $a v$ spinules in apical third; with a row of fine $p v$ setae in basal $\frac{3}{5}$, the longest of which equal or almost equal femoral depth, decreasing in length apicad; $a$ surface with a row of short stout setae in basal half, strongest around middle; $3 d$-p preapical setae. Mid tibia with $2 p$ setae. Hind femur with a complete row of short $p v$ setae, hair-like near base, stronger around middle, short and spinulose near apex (Text-fig. 39); av surface with a complete row of short setae, fine in basal half and spine-like in apical half (Text-fig. 4I); $a d$ row complete; I $d$ and I $p d$ preapical setae. Hind tibia with I strong ad seta; some of the $p d$ ground-setulae more erect in apical half, with a strong setula apicad of the $a d ; d$ preapical subequal to tibial depth, stronger than the $a d$. Wings : Rather yellow costally and basally, otherwise faintly but conspicuously smoky. Epaulet and basicosta yellow. Subcostal sclerite bare. Costa setulose ventrally as far as the apex of vein 2, the spine inconspicuous. Stem-vein with a few short hairs below. Small cross-vein placed basad of the point where vein I enters costa. Hind cross-vein oblique, sinuate. Vein I bare. Vein 3 bare above, rarely with a few setulae on the node at base; below with a few setulae on the node at base. Vein 4 inclined weakly forward towards vein 3 in apical section. Squamae and margins deep yellow, margins pale. Knob of halteres deep yellow. Abdomen: Tergite I +2 yellow, with a dark hind-margin; tergites 3 and 4 entirely dark, paler laterally; tergite 5 dark, posterior half or more yellow. Sternites orange-yellow. In posterior view, tergites weakly and thinly brownish-grey dusted except for a median vitta and the hind-margins. Macrochaetae quite well-developed: tergites 3-5 with some lateral discals, tergites 3 and 4 with some lateral marginals, and tergite 5 with a marginal row. Sternite I dark setulose. Genitalia: Text-figs. 89, 92, 95. Measurements: Length of body, $6 \cdot 5-7 \cdot 5 \mathrm{~mm}$. Length of wing, $6 \cdot 0-7 \cdot 0 \mathrm{~mm}$.

ㅇ. Differs from the male as follows: Head: Eyes broadly separated; frons at middle less than an eye-width, broadening gradually to lunula (Text-fig. 27). Upper inner eye-facets not enlarged. Ocellar setae strong, longer than both prst $d c$ setae, directed forwards and slightly outwards. $V t i$ strong, directed upwards and slightly inwards, one and a half times length of the outcurved vte; vte twice as long as an adjacent post-ocular setula, slightly longer than the fine outcurved pvt. Parafrontal pruinosity tinged with yellow at upper two-thirds, above that yellowish grey. Interfrontalia red or black in ground-colour; viewed from below, greyish pruinose with the frontal triangle brownish grey; frontal triangle otherwise visible as a subshining black streak extending only half distance from anterior ocellus to lunula. Parafrontalia slender, broadening gradually towards lunula; at middle a parafrontale equal to one and a half times diameter of anterior ocellus and quarter width of interfrontalia, at lunula less than width of 3 rd antennal segment. Interfrontalia with the margins almost straight, diverging from vertex to lunula, at lunula broader than a parafrontale, bare (Text-fig. 27). I pair of strong inclinate ori at lunula, with 3-4 weaker pairs above that are directed forwards and inwards, all on lower half of frons; 2 pairs of strong reclinate ors, the upper pair slightly stronger and placed closer to lower pair than to vti; parafrontalia otherwise with short proclinate setulae on upper half. Parafacialia slightly broader, opposite insertion of arista equal to one and a half times diameter of anterior ocellus. In lateral view, parafrontalia but not parafacialia visible. Facial ridges without setulae above the cluster at vibrissal angle. Thorax: Viewed from above and behind, mesonotum virtually undusted, with white dusted markings as follows: a median vitta, and a pair of paramedian vittae through $d c$, from neck to 2nd post $d c$, tapering behind; a dot at suture on $i a$ line; and weak indications of a lateral fascia along suture. Setae stronger than in male. Prsc acr on or behind the transverse level of prsc $d c$. Anterior prst $d c$ half length of posterior one. Anterior $i a$ strong. Notopleuron with dark setulae, around 2nd seta only. Pteropleural setulae golden below subalar ridge. Scutellum with 9-I3 setulae in I-2 irregular rows below the level of the strong setae. Legs: Yellow, tarsi black. Fore femur without av spinules. Mid femur without ventral setae, except for a curled $v$ at base. Hind femur with a row of 3-5 strong $a v$ in apical $\frac{2}{5}$; on pv surface with a single seta at apical $\frac{2}{5}$, between this and apex with a few stronger setulae. Hind tibia with 2 av setae; the $p d$ quite strong; ad preapical seta stronger than the $d$. Wings: Hind cross-vein 
more oblique and sinuate. Vein 3 with a few short setulae above on the node at base. Abdomen: Yellow; with some darker shadows on tergite 3 , and a pair of large quadrate spots on tergite 4 separated on a mid-line ( $\mathrm{I}$ 9) ; or with tergite 3 dark except for pale lateral anterior crescents, and tergite 4 almost entirely dark ( $\mathrm{I}$ \&). Virtually undusted, even in posterior view. Macrochaetae as in Text-fig. 25. Sternite I pale setulose. Measurements: Length of body, $8 \cdot 0 \mathrm{~mm}$. Length of wing, $7 \cdot 5 \mathrm{~mm}$.

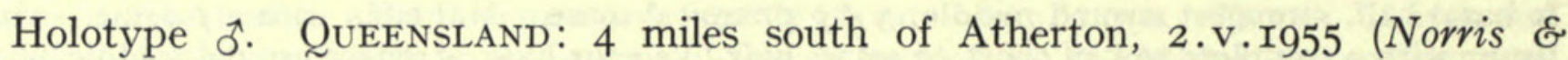
Common), CSIRO.

Paratypes, 4 ô, 2 우. QueEnsland: Bamboo Creek, near Miallo, N. of Mossman,

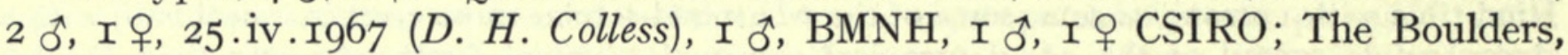
Babinda, I $\hat{\jmath}$, Io.v. I967 (D. H. Colless), CSIRO; Crystal Cascades, Cairns, I $\widehat{o}$ I9.iv. I967 (D. H. Colless), CSIRO; I o (Brunetti Coll.), BMNH.

Distribution and biology: Australia: Queensland. A rare species. This species has been found exclusively in lowland rain forest. Life-history and immature stages unknown.

Variation: A very consistent species in colour and structure. The minor variations observed are noted in the description.

Affinities: D. spinuligera is very closely related to latitarsis (Stein), which has been recorded from New Guinea (Stein, Igrg : 207). These two species share such striking characters as the presence of an $a d$ as well as an $a$ preapical seta on mid femur, the arrangement of abdominal macrochaetae in the female (Text-fig. 25), the conspicuously forward-directed ori in the female (Text-fig. 27), and the dilated 3 rd to 5 th fore tarsal segments in the female (Text-fig. 29). D. latitarsis is a much darker species, with the ground-colour of the thorax very extensively dark; paler specimens are known, but these always have at least the triangular sclerite below infra-alar bulla dark. In latitarsis the vallar ridge is always haired anteriorly and the scutellum is dusted in basal lateral corners; the male lacks the $a v$ spinules on fore and mid femora, and the female has black hairs or setulae on squamopleuron, supra-spiracular convexity, and hypopleuron below spiracle.

\section{Dichaetomyia fusconota sp. n.}

(Text-figs. 24, 26, 28, 38, 40, 90, 93, 96)

Diagnosis: D. fusconota can be distinguished from all other Australian Dichaetomyia by the mainly dark femora, pleura and mesonotum.

๙. Head: Frons slender, at narrowest point eyes separated by diameter of anterior ocellus. Eyes virtually bare, with only the usual microscopic pubescence; upper inner facets enlarged as usual but not conspicuously so. Ocellar setae fine, subequal to (holotype) or shorter than (paratype) anterior prst $d c$. Vertical setae short, only slightly longer than adjacent post-ocularsetulae. Post-ocular setulae very short, with several scattered setulae below the upper row which are entirely black. Parafrontalia, parafacialia and face silvery white pruinose; genae reddish brown in ground-colour, brownish grey pruinose. Interfrontalia, viewed from below, with the visible parts grey pruinose. Parafrontalia slender, at lunula equal to one and a half times diameter of anterior ocellus. Interfrontalia reduced, two small triangles visible before ocellar tubercle and at lunula, visible as a seam or even partially obsolete on median third of frons. 3-4 pairs of inclinate ori, decreasing in size above, with a few hair-like interstitials, all on lower half of frons; with or without I pair of hair-like reclinate ors just before ocellar tubercle. Antennae and basal third of 
arista yellow; 3rd segment white pruinose. 3rd segment three times as long as broad, in frontal view almost reaching epistoma. Arista with long regular plumosity, the longest of which equals length of 3rd antennal segment. Parafacialia slender, opposite insertion of arista equal to diameter of anterior ocellus. Parafacialia and genae bare. In lateral view, parafrontalia mainly visible, parafacialia visible though slender; vibrissal angle projecting slightly beyond profrons. Genae slender; the depth below lowest eye-margin equal to slightly less than width of 3rd antennal segment. Peristomal setae rather dense, especially behind. Facial ridges with short hairs ascending to midway level of 3rd antennal segment. Mentum of proboscis brown. Palpi compressed, rather slender, weakly clavate towards tips. Thorax: Mesonotum brownish, yellow at sides, with a dark brown to black median vitta from neck to 2nd post $d c$ and a pair of brown vittae outside $d c$ from 2nd prst to 3 rd post $d c$. Pleura partially infuscated, with black patches on mesopleuron, sternopleuron, hypopleuron and pteropleuron, and the triangular sclerite below infra-alar bulla black. Scutellum yellow; metanotum below scutellum dark brown. Viewed from above and behind, mesonotum whitish to yellowish grey dusted, with thinly dusted markings as follows: a pair of paramedian vittae mesad of the $d c$, narrow at neck, broader and becoming obsolescent after suture; a pair of prst patches between $p h$ and $d c$; and 2 pairs of post vittae, between $i a$ and $d c$ and through the $s a$; a broad prsc fascia between prsc setae and scutellum completely undusted. Scutellum undusted, or inconspicuously dusted around the sub-basal lateral setae. Pleura grey dusted on the dark patches. Anterior spiracle yellow. Mesonotum with the ground-setulae rather fine and sparse, except between the $d c$; all thoracic ground-setulae black unless otherwise stated. $A c r o+\mathrm{I}$, the single ( $p r s c$ ) pair welldeveloped, placed behind the transverse level of prsc $d c$ and closer to each other than to the $d c$; prst setulae irregularly 8-serial. $2 h$, the outer one one and a half times length of the inner one. $2 p h$, the posterior one one and a half times length of the anterior one. $2 i a$, the anterior one well developed. $2 s a$, the posterior one weak. Pra well-developed but short, half length of 2nd $n p l$ (holotype), or hair-like (paratype). Post-alar callus with 2 setae, with setulae present on the ridge between inner seta and scutellum. Post-alar declivity with a few golden hairs. Suprasquamal ridge bare. Prosternum black setulose, some of the anterior setulae paler. Propleural depression bare. I propleural and I prostigmatal seta, the latter with I-2 well-developed auxiliary setae below; the former surrounded by few, the latter by numerous, setulae. Ist $n p l$ longer and stronger than 2nd; disc of notopleuron with dark setulae around base of posterior seta only. Mesopleuron with 4-5 strong setae in caudal row, and a conspicuous black setula in upper anterior corner. Infra-alar bulla yellow, bare. Pteropleuron with the setulae entirely black; those on sub-alar ridge confined to anterior part, descending down to sternopleural and hypopleural margins. Vallar ridge bare. Stpl I +2 , the lower one subequal to anterior one and much closer to posterior one than to anterior one. Metathoracic spiracle quite large, subtriangular, with a row of quite long setulae along lower and posterior margins. Scutellum with a very strong apical and sub-basal lateral pair of setae. Disc with rather short dense setulae, a few stronger ones apically; 5-7 setulae descending just below the level of the strong setae, otherwise bare laterally and ventrally. Legs: Coxae and trochanters yellow, coxae sometimes with dark shadows above; femora dark on all but apical $\frac{1}{4}$ to $\frac{1}{5}$; tibiae yellow. Tarsi unremarkable. Fore femur with a complete row of $p v$ setae. Mid femur with a row of $p v$ setae in basal half, the longest equal to femoral depth, becoming shorter towards middle; without av setae; $3 d-p$ preapical setae. Mid tibia with $2 p$ setae. Hind femur on $a v$ surface with a few setae near base and a strong row in apical half (Text-fig. 40); on pv surface with a row of strong setae from base almost to apex (Text-fig. 38), decreasing in length apicad, the longest equal to femoral depth; ad row complete; I $d$ and I $p d$ preapical setae. Hind tibia with I $a d$ seta; some of the $p d$ ground-setulae more erect in apical half; ad preapical slightly exceeding tibial depth, shorter than the $d$. Wings: Conspicuously yellowish-brown clouded. Epaulet and basicosta yellow. Subcostal sclerite bare. Costa setulose ventrally as far as the apex of vein 2 , the spine inconspicuous. Stem-vein bare above, with a few dark hairs below. Small cross-vein placed basad of the point where vein I enters costa. Hind cross-vein oblique, sinuate. Vein I bare. Vein 3 bare above; below with a few setulae on the node at base sometimes extending halfway to small cross-vein. Vein 4 inclined weakly forward towards vein 3 in apical section. Squamae and margins yellow to deep 
yellow, lower deeper than upper, fringes pale. Knob of halteres deep yellow. Abdomen: In posterior view, tergites appearing dull and with some inconspicuous whitish dust. Macrochaetae reduced: tergites 3 and 4 with some lateral marginals, tergite 5 with a marginal row, tergites 4 and 5 with some lateral discals. Genitalia: Text-figs. 90, 93, 96. Measurements: Length of body, $7 \cdot 0-7 \cdot 5 \mathrm{~mm}$. Length of wing, $6 \cdot 5-7 \cdot 0 \mathrm{~mm}$.

ㅇ. Differs from the male as follows. Head: Eyes broadly separated; frons at middle less than an eye-width, broadening gradually to lunula (Text-fig. 26). Upper inner eye-facets not enlarged. Ocellar setae strong, directed forwards and slightly outwards, slightly shorter than 2nd prst $d c$ seta. Vti strong, directed upwards and slightly inwards, one and a half times length of the outcurved vte; vte three times as long as an adjacent post-ocular setula, longer than the outcurved pvt. Parafrontal pruinosity becoming grey to yellowish grey above. Interfrontalia black in ground-colour; viewed from below, grey pruinose with the frontal triangle sometimes more brownish; frontal triangle otherwise visible as a subshining black streak extending three-fifths distance from anterior ocellus to lunula. Parafrontalia slender, broadening gradually towards lunula; at middle a parafrontale equal to twice diameter of anterior ocellus and one-fifth width of interfrontalia, at lunula broader than width of 3 rd antennal segment. Interfrontalia with the margins convex, broadest at middle of frons, at lunula a little broader than a parafrontale, bare (Text-fig. 26). I pair of strong inclinate ori at lunula, with 3-5 weaker pairs above that are directed inwards, all on lower two-thirds of frons; 2 pairs of strong reclinate ors, the upper pair stronger and placed closer to lower pair than to $v t i$; parafrontalia otherwise with a few short proclinate setulae on median half. 3rd antennal segment infuscated beyond arista. Parafacialia slightly broader, opposite insertion of arista equal to almost twice diameter of anterior ocellus. Thorax: Pleura slightly less extensively infuscated. Viewed from above and behind, mesonotum dusted as in male, but the undusted markings more conspicuous; the paramedian vittae mesad of the $d c$ broad behind suture, twice as broad as they are before suture. Scutellum undusted. Legs : Fore femur yellow, mid and hind femora extensively but irregularly darkened. Femoral setae as in male, but slightly weaker. Wings: Squamae and fringes paler, lighter yellow. Abdomen: Colour as in male, chaetotaxy as in Text-fig. 24. Measurements: Length of body, $6.0 \mathrm{~mm}$. Length of wing, $5.5 \mathrm{~mm}$.

Holotype ô. QueEnsland: Io miles south of Daintree, 29.iv. I955 (K. R. Norris), CSIRO.

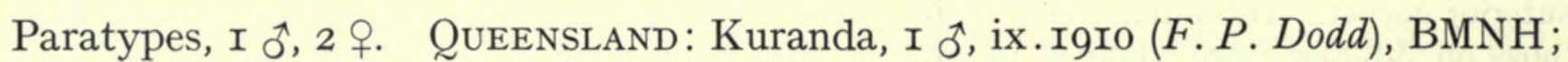
Kuranda, I + , ix. I9ro (Brunetti Coll.), BMNH; Kuranda, I + , I7.v.r958 (D. K. McAlpine), Aust. Mus.

Distribution and biology: Australia: Queensland. A rare species.

This species has been found in rain forest, up to $330 \mathrm{~m}$., and in riverine scrub in savannah woodland. Life-history and immature stages unknown.

Variation: A very consistent species in colour and structure. The minor variations observed are noted in the description.

Affinities: $D$. fusconota has a superficial resemblance to several of the darker species of the rufescens-group. D. incerta (Stein) has the pleura yellow and hind femur without $p v$ setae. $\quad$. sabroskyi Snyder, known to me from the description only, is similar in having a mainly dark thorax and numerous $a v$ and $p v$ setae on hind femur. It differs from fusconota in having dark coxae, trochanters and tibiae; without clearly defined dorsal vittae on mesonotum; abdomen mainly black in ground-colour; scutellum black. D. fusconota appears to be closest to nigroscuta Bohart and Gressitt, which is known to me from descriptions only and which differs in details of colour and leg chaetotaxy, in particular hind femur with only I-2 $p v$ setae. 


\title{
Dichaetomyia apicalis (Stein)
}

\author{
(Text-figs. 97, I00, I03)
}

Spilogaster apicalis Stein, I904: го3. Holotype $\hat{0}$, JAVA. In the Zoölogisch Museum der Universiteit van Amsterdam. [Examined.]

This species is known to me from the holotype and from a good series of both sexes in the BMNH. I consider it to be a strictly Oriental species, and doubt if it will be found to the East of the Weber Line. A female from Soembawa, identified by Hennig (I952: 83), is in my opinion not apicalis: it has the ori above the lower pair directed inwards, as in soror but not as in apicalis and arrogans. I have not seen apicalis from New Guinea. I have been unable to study any material from Micronesia identified as apicalis by Snyder (I965:303).

D. apicalis is very closely related to arrogans and soror, and will be traced to couplet $2 \mathrm{I}$ in the key.

It differs from soror by the following characters: hind tibia with 2 av setae, at least the triangular sclerite below infra-alar bulla brown, more numerous scutellar setulae below the level of the strong setae, abdominal setae less numerous, auxiliary propleural and prostigmatal setae weak to absent, of ori above the lower pair directed forwards and inwards.

It is most closely related to arrogans by reason of the weak auxiliary prostigmatal seta, weak abdominal setae with no discal row on tergite 5 , hind tibia with 2 av setae, o or $i$ above the lower pair directed forwards and inwards. It differs from arrogans by the following characters: mesonotum densely dusted, especially before suture, with only traces of undusted vittae (with only thin dust in arrogans, through prst dc setae, along suture, and through post ia setae); hypopleuron with hairs below spiracle (bare in arrogans); scutellum with more numerous setulae, about I3, below the level of the lateral setae (fewer in arrogans, 5-9); palpi entirely brown (at most basal part brown in arrogans); post-ocular setulae and beard entirely dark (both partly golden in arrogans).

The male $5^{\text {th }}$ sternite is unlike that of soror and arrogans (Text-fig. 97). It has the median cleft well-developed, and lacks stout setulae medially, on either side of this cleft. The cercal plate possesses rudimentary " nipples " that are scarcely indicated in soror and arrogans.

\section{Dichaetomyia rufescens (Stein)}

Spilogaster rufescens Stein, I900b : 134. Lectotype $\widehat{\jmath}$, NEw GuineA: Simbang, Huon-Golf. In the Zoologisches Museum der Humboldt-Universität zu Berlin. [Examined.] [Designated by Pont, in press.]

This species is known to me only from a few males, from New Guinea. It is very closely related to arrogans and soror, and will be traced to couplet $2 \mathrm{I}$ in the key.

It differs from soror by the following characters: hind tibia with 2 av setae; hypopleuron bare below spiracle; beard with many golden setae; scutellum with more numerous setulae, I3-I4, below the level of the strong setae. 
It differs from arrogans, to which it is most closely related, by the following characters: post-ocular setulae entirely golden below the upper row (black above in arrogans); palpi entirely yellow (brown at base in arrogans); scutellum with more numerous setulae, I3-I4, below the level of the strong setae (fewer in arrogans, 5-9); mesonotum densely dusted, especially before suture, with only traces of undusted vittae (with only thin dust in arrogans, through prst $d c$ setae, along suture and through post ia setae).

I have not had a male available for a genital dissection. In dry specimens, how-

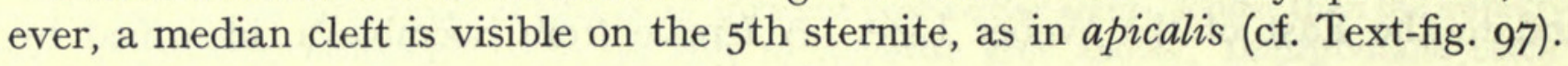

\section{Dichaetomyia arrogans sp. $\mathrm{n}$.}

\section{(Text-figs. 98, ror, I04)}

Diagnosis: $D$. arrogans can be distinguished from the other Australian species of the rufescens-group by the yellow palpi, hind femur without $p v$ setae in the male, and fore tarsi not dilated in female.

o. Head: Frons slender, at narrowest point eyes separated by slightly over diameter of anterior ocellus. Eyes virtually bare, with only the usual microscopic pubescence; upper inner facets enlarged as usual but not conspicuously so. Ocellar setae well developed, longer than anterior prst $d c$, in some individuals slightly shorter. Vertical setae short, only slightly longer than the adjacent post-ocular setulae. Post-ocular setulae very short, with several scattered setulae below the upper row, which are dark above but become golden below. Parafrontalia, parafacialia and face silvery white pruinose; genae black in ground-colour, brownish grey pruinose. Interfrontalia, viewed from below, with the visible parts grey pruinose. Parafrontalia slender, at lunula equal to twice diameter of anterior ocellus. Interfrontalia reduced, two small triangles visible, an elongate one before ocellar tubercle and a short one at lunula, visible as a seam or obsolete on median one-third to half of frons. 3-4 pairs of weak inclinate ori, with several hair-like interstitials, all on lower third of frons; I (-2) pairs of hair-like reclinate ors just before ocellar tubercle, sometimes with a tiny proclinate pair in front of them. Antennae and basal quarter of arista yellow; 3rd segment pale yellow, white pruinose. 3rd segment three times as long as broad, in frontal view reaching or almost reaching epistoma. Arista with long regular plumosity, the longest of which equals length of 3 rd antennal segment. Parafacialia slender, opposite insertion of arista equal to diameter of anterior ocellus. Parafacialia and genae bare. In lateral view, parafrontalia and parafacialia largely obscured; vibrissal angle projecting slightly beyond profrons. Genae slender; the depth below lowest eye-margin equal to less than width of 3rd antennal segment. Peristomal setae rather dense, especially behind. Facial ridges with short hairs ascending to at least midway level of 3 rd antennal segment. Mentum of proboscis brown. Palpi compressed, rather slender, weakly clavate towards tips. Thorax: Thorax and scutellum yellow in ground-colour, the triangular sclerite below infra-alar bulla seamed with brown. Viewed from above and behind, mesonotum undusted except for some thin whitish dust through prst $d c$ setae, a fascia running laterad along suture, and a vitta through post ia; this dust sometimes very indistinct. Scutellum appearing undusted. Pleura virtually undusted. Anterior spiracle pale yellow. Mesonotum with the ground-setulae rather short and sparse, except those between the $d c$; all thoracic ground-setulae black unless otherwise stated. $A c r$ $o+I$, the single ( $p r s c)$ pair well-developed, placed behind, on or in front of the transverse level of prsc $d c$ and closer to each other than to the $d c$; prst setulae irregularly ro- to II-serial. $2 h$, the outer one one and a half times length of the inner one. $2 p h$, the posterior one twice length of the anterior one. $2 \mathrm{ia}$, the anterior one weak to strong. $2 s a$, the posterior one weak. Post-alar callus with 2 setae, with setulae present on the ridge between inner seta and scutellum. Postalar declivity with a few golden to dark hairs. Supra-squamal ridge bare. Prosternum pale 
setulose. Propleural depression bare. I propleural and I prostigmatal seta, each with a weak auxiliary seta below, the auxiliary prostigmatal very fine or even absent; the former surrounded by few, the latter by numerous, pale setulae. Ist $n p l$ longer and stronger than $2 \mathrm{nd}$; disc of notopleuron with dark setulae around the bases of both setae, those around anterior seta sometimes pale. Mesopleuron with 4 strong setae in caudal row, and a conspicuous black setula in upper anterior corner; ground-setulae almost entirely pale. Infra-alar bulla yellow, bare. Pteropleuron with the setulae dark, some of the lower ones pale-tipped or wholly pale; those on subalar ridge confined to anterior part, descending down to sternopleural and hypopleural margins. Vallar ridge bare or haired on anterior part. Stpl I +2 , the lower one a little weaker than anterior one and much closer to posterior one than to anterior one. Hypopleuron with some pale hairs on metepisternum. Metathoracic spiracle moderate, subtriangular, with a few setulae on lower and posterior margins. Squamopleuron with a few pale and dark hairs. Scutellum with a very strong apical and sub-basal lateral pair of setae. Disc with rather short dense setulae, several stronger ones apically; 5-9 setulae descending in an irregular row just below the level of the strong setae, otherwise bare laterally and ventrally. Legs : Yellow, tarsi becoming brown after metatarsus. Tarsi unremarkable. Fore femur with a complete row of $p v$ setae. Mid femur without ventral setae, though a few of the $p v$ ground-setulae in basal third may be rather longer, equal to half femoral depth; 3 (rarely 4 ) $d$-p preapical setae. Mid tibia with $2 p$ setae. Hind femur with 2-4 weak av setae in apical third, not as long as femoral depth, otherwise without ventral setae; $a d$ row complete; I $d$ and I $p d$ preapical setae. Hind tibia with I $a d$ seta; some of the $p d$ ground-setulae more erect in apical half; $d$ preapical seta subequal to tibial depth, shorter than the $a d$. Wings: Rather yellowish tinged, especially costally and basally, sometimes apical half smoky. Epaulet and basicosta yellow. Subcostal sclerite bare. Costa setulose ventrally as far as the apex of vein 2, the spine inconspicuous. Stem-vein with a few fine hairs above and below. Small cross-vein placed below or basad of the point where vein I enters costa. Hind cross-vein oblique, sinuate. Vein I bare. Vein 3 bare above; below with a few setulae on the node at base or just beyond. Vein 4 inclined weakly forward towards vein 3 in apical section. Squamae and margins rather deep yellow, fringes yellow. Knob of halteres rather deep yellow. Abdomen: Ground-colour basically yellow, with variable dark markings: tergite $\mathrm{I}+2$ yellow to dark; tergites 3 and 4 partly to entirely black, rarely almost entirely yellow; tergite 5 yellow or yellow only on posterior third; the dark areas with a rather violet sheen. Sternites I-4 yellow sometimes also part of sternite 5. In posterior view, tergites with the dark areas thinly and uniformly grey dusted, otherwise appearing rather matt. Macrochaetae quite well-developed and erect: tergite 3 with a lateral marginal, tergite 4 with some lateral discals and marginals, tergite 5 with some lateral discals and a marginal row. Sternite I dark to pale setulose. Genitalia: Text-figs. 98, Iог, I04. Measurements: Length of body, $6 \cdot 0-7.5 \mathrm{~mm}$. Length of wing, $5 \cdot 5-7 \cdot 0 \mathrm{~mm}$.

․ Differs from the male as follows. Head: Eyes broadly separated; frons at middle less than an eye-width, broadening gradually to lunula. Upper inner eye-facets not enlarged. Ocellar setae strong, almost as long as 2nd prst $d c$ seta, directed forwards and slightly outwards. $V t i$ strong, directed upwards and slightly inwards, longer than the outcurved vte; vte 2-3 times as long as an adjacent post-ocular setula, longer than the fine outcurved pvt. Parafrontal pruinosity becoming thinner and greyer in upper half, virtually subshining black alongside ocellar tubercle. Interfrontalia black in ground-colour, brick-red in immature specimens; viewed from below, grey pruinose with the frontal triangle tinged with brownish; frontal triangle otherwise visible as a subshining black streak almost reaching to lunula. Parafrontalia slender, not broadening much except just before lunula; at middle a parafrontale equal to one and a half times diameter of anterior ocellus and quarter width of interfrontalia, at lunula less than width of interfrontalia. Interfrontalia with the margins diverging slightly from vertex to lunula, at lunula broader than a parafrontale (as in spinuligera, Text-fig. 27), bare. I pair of strong inclinate ori at lunula, with 3-4 weaker pairs above, all on lower half of frons; 2 pairs of strong reclinate ors, the upper one twice as long as lower one and placed closer to it than to vti; parafrontalia otherwise with a few short proclinate setulae on lower half. 3rd antennal segment yellow, weakly infuscated in apical half. Palpi rather broader. Thorax: Viewed from above and behind, mesonotum with the dust 
very reduced, usually only the lateral fascia along suture present; sometimes with traces of a faint dusted median vitta before suture. Notopleuron sometimes bare around ist seta. Hypopleuron usually with some pale hairs below spiracle. Scutellum with 7-9 setulae just below the level of the strong setae. Legs: Tarsi rather paler. Wings: Hind cross-vein usually less sinuate. Vein 3 sometimes with a setula above on the node at base. Lower squama often rather deeper yellow on outer part. Abdomen: Ground-colour varying as in male; often almost entirely yellow. Macrochaetae reduced, fewer and weaker: virtually absent except for a lateral discal and marginal row on tergite 5 , and a weak lateral discal and marginal on tergite 4. Measurements: Length of body, $6 \cdot 0-7 \cdot 5 \mathrm{~mm}$. Length of wing, $5 \cdot 5-7 \cdot 0 \mathrm{~mm}$.

Holotype ơ. Queensland: Iron Range, Ir.iv.Ig64 (I. F. B. Common \& M.S. Upton), CSIRO.

Paratypes, $9 \hat{0}$, 2I + . Queensland: Upper Mulgrave River, ro miles Golds-

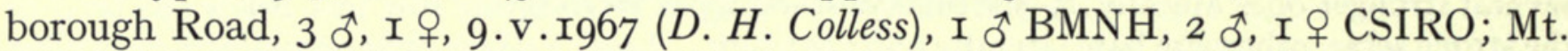
Edith Forest Road, I mile off Danbulla Road, I o, 6.v.I967 (D. H. Colless), CSIRO; Mossman Gorge, I ô, 24.iv. I967 (D. H. Colless), CSIRO; Whitfield Range Forest Reserve, Cairns, I ô, I9.iv.I967 (D. H. Colless), CSIRO; Crystal Cascades, Cairns, 2 ô, I + , rg.iv. I967 (D. H. Colless), I ô BMNH, I ô, I + CSIRO; Tolga, I + , 30.iv. I955 (K. R. Norris), BMNH; Mt. Bartle Frere, East base, 80 ft., I ㅇ, 24.iv. I955 (K. R. Norris), BMNH; I mile E. of Kuranda, I + 4.v.I955 (Norris \& Common), CSIRO; Tinaroo Dam, Atherton Tbld, I 9 , 7.xii. I965, CSIRO; Io miles S. of Daintree, I + , 25.iv. I967 (D. H. Colless), CSIRO; Yungaburra (State Forest 452), I + , 29.iv. I967 (D. H. Colless), CSIRO; Kuranda Range State Forest, I + , 20.iv. I967 (D. H. Colless), CSIRO; Mulgrave River, 4 miles W. of Gordonvale, I ㅇ, I3.i.rg67 (D. K. McAlpine), Aust. Mus.; Thornton Range, near Daintree River, I ㅇ, 7.i. I967 (D. K. McAlpine \& G. Holloway), Aust. Mus.; The Intake via Redlynch, 2 q, 30.xii. I966 (D. K. McAlpine \& G. Holloway), Aust. Mus.; Kuranda, I +, ix. I9ro (Brunetti Coll.), BMNH; Kuranda, I ㅇ, x. IgIo (Brunetti Coll.), BMNH; 4 ㅇ (Brunetti Coll.), BMNH; Kuranda, I ㅇ, Ir .iii. I956 (J. L. Gressitt), Bishop; Deeral, ex Acmena macrocarpa, I ô, 27.vi. I950 (W. A. Smith), Qld. Dept. Pr. Ind.; Cairns, ex Fagraea cambagei, I + , 27.vi. I950 (W. A. Smith), Qld. Dept. Pr. Ind.

Distribution and biology: Australia: Queensland. An uncommon species.

This species occurs in lowland rain forest. It is not clear whether the data associating the species with Acmena macrocarpa White, I942 (Myrtaceae), and Fagraea cambagei Domin, I928 (Potaliaceae), refer to breeding records or to adult habits: I assume the latter. Life-history and immature stages unknown.

Variation: The abdominal colour varies, as noted in the description, from almost entirely dark through various degrees of banding to entirely yellow. One female (Tinaroo Dam) has the mesonotum rather generally but thinly grey dusted. Mid femur rarely has an ad preapical seta: in the male, it is present on both sides in one specimen, on one side only in one specimen, and absent in all others; in the female, it is present on one side only in one specimen, and absent in all others. The hind tibia has $2-3$ av setae in all specimens, except for one male which has one on one side and one female which has one on both sides.

Affinities: D. arrogans is most closely related to the Australian soror, the New Guinea rufescens and the Oriental apicalis. Its affinities with these species are shown 
in the key (p. 209) and in the notes under apicalis and rufescens. The structure of the male 5 th sternite (Text-fig. 98) differs from that of all three species by the virtual absence of a deep median cleft.

\section{Dichaetomyia soror sp. n.}

$$
\text { (Text-figs. 99, 102, 105) }
$$

Dichaetomyia apicalis (Stein); Malloch, I925 : 326 [misidentification].

Dichaetomyia apicalis (Stein); Lee, Crust \& Sabrosky, 1956 : 307 [misidentification].

Diagnosis: D. soror can be distinguished from the other Australian species of the rufescens-group by the dark palpi, entirely yellow mesonotum and legs, and the absence of $p v$ setae on hind femur.

๙. Head: Frons slender, at narrowest point eyes separated by less than diameter of anterior ocellus. Eyes virtually bare, with only the usual microscopic pubescence; upper inner facets enlarged as usual but not conspicuously so. Ocellar setae fine, not as long as anterior prst $d c$. Vertical setae short, only slightly longer than adjacent post-ocular setulae. Post-ocular setulae very short, with several scattered setulae below the upper row, which are entirely black. Parafrontalia, parafacialia and face silvery white pruinose; genae black in ground-colour, greyish pruinose. Interfrontalia, viewed from below, with the visible parts grey pruinose. Parafrontalia slender, at lunula equal to one and a half times diameter of anterior ocellus. Interfrontalia reduced, two small triangles visible before ocellar tubercle and at lunula, visible as a seam or even obsolete on median third of frons. 4-5 pairs of inclinate ori, decreasing in size above the strong pair at lunula, on lower two-fifths of frons; I pair of hair-like reclinate ors just before ocellar tubercle. Antennae and basal third of arista yellow; 3rd segment pale yellow, white pruinose. 3rd segment three times as long as broad, in frontal view almost reaching epistoma. Arista with long regular plumosity, the longest of which equals length of 3 rd antennal segment. Parafacialia slender, opposite insertion of arista equal to diameter of anterior ocellus. Parafacialia and genae bare. In lateral view, parafrontalia and parafacialia largely obscured; vibrissal angle projecting slightly beyond profrons. Genae slender; the depth below lowest eye-margin equal to less than width of 3 rd antennal segment. Peristomal setae rather dense, especially behind. Facial ridges with short hairs ascending to midway level of 3 rd antennal segment. Mentum of proboscis dark brown. Palpi compressed, rather slender, weakly clavate towards tips. Thorax: Thorax and scutellum entirely yellow in ground-colour. Viewed from above and behind, mesonotum rather densely whitish dusted, with thinly dusted or undusted markings as follows: a pair of paramedian vittae mesad of the $d c$, from neck to behind suture where they become obsolescent; a pair of prst patches between $p h$ and $d c$; a pair of post vittae between $i a$ and $d c$; and a pair of vittae through $s a$. Scutellum appearing undusted, in extreme posterior view with some dull dust apparent. Pleura virtually undusted. Anterior spiracle pale yellow. Mesonotum with the ground-setulae rather short and sparse, except those between the $d c$; all thoracic ground-setulae black unless otherwise stated. $\mathrm{Acr}$ o $+\mathrm{I}$, the single (prsc) pair welldeveloped, placed behind the transverse level of prsc $d c$ (on this level in the male from East Point) and closer to each other than to the $d c$; prst setulae irregularly 8 - to 9-serial. $2 h$, the outer one one and a half times length of the inner one. 2 ph, the posterior one one and a half times length of the anterior one. $2 \mathrm{ia}$, the anterior one hair-like. $2 \mathrm{sa}$, the posterior one weak. Post-alar callus with 2 setae, with setulae present on the ridge between inner seta and scutellum. Post-alar declivity with a few pale hairs. Supra-squamal ridge bare. Prosternum pale setulose, sometimes brown setulose (in two of every five specimens). Propleural depression bare. I propleural and I prostigmatal seta, each with a well-developed auxiliary seta below; the former surrounded by few, the latter by numerous, pale and dark setulae. Ist $n p l$ longer and stronger than 2nd; disc of notopleuron with dark setulae around the base of posterior seta, and pale or dark ones around the base of anterior seta. Mesopleuron with 4 strong setae in caudal row, and a 
conspicuous black setula in upper anterior corner; ground-setulae entirely dark. Infra-alar bulla yellow, bare. Pteropleuron with the setulae mainly black, several of those below the sub-alar ridge brown to golden; those on sub-alar ridge confined to anterior part, descending down to sternopleural and hypopleural margins. Vallar ridge with some pale, rarely dark, hairs on anterior part, bare in one male from Earl Hill. $S t p l \mathrm{I}+2$, the lower one usually weaker than anterior one and much closer to posterior one than to anterior one. Hypopleuron with a few pale or dark hairs on metepisternum. Metathoracic spiracle moderate, subtriangular, with a few setulae on lower and posterior margins. Squamopleuron with pale or dark hairs. Scutellum with a very strong and sub-basal lateral pair of setae. Disc with rather short dense setulae, several stronger ones apically; 4-5 setulae descending just below the level of the strong setae, otherwise bare laterally and ventrally. Legs: Yellow, metatarsi dull to brown, other tarsi brown; sometimes hind tibia dark. Tarsi unremarkable. Fore femur with a complete row of $p v$ setae. Mid femur without $a v$ or $p v$ setae, though the ground-setulae rather longer in basal half; $3 d-p$ preapical setae. Mid tibia with $2 p$ setae. Hind femur with 3-4 av setae in apical third, the longest equal to femoral depth, and with or without 2-3 short $p v$ setae around middle, equal to half femoral depth, otherwise bare on ventral surfaces; $a d$ row complete; I $d$ and I $p d$ preapical setae. Hind tibia with I ad seta; some of the $p d$ ground-setulae more erect in apical half, with a rather strong one at about level of the $a d ; d$ preapical seta subequal to tibial depth, shorter than the $a d$. Wings: Clear, weakly yellowish costally and basally; sometimes weakly smoky, and yellower costally. Epaulet and basicosta yellow. Subcostal sclerite bare. Costa setulose ventrally as far as the apex of vein 2, the spine inconspicuous. Stem-vein with a few tiny pale hairs at base above (bare in one male from Earl Hill), and a few hairs below. Small cross-vein placed basad of the point where vein I enters costa. Hind cross-vein oblique, sinuate. Vein I bare. Vein 3 bare above, rarely with a setula on the node at base; below with a few setulae on the node at base and just beyond. Vein 4 inclined weakly forward towards vein 3 in apical section. Squamae and margins yellow, lower one deeper, fringes pale. Knob of halteres deep yellow. Abdomen: Ground-colour yellow, with variable dark markings: tergites 4 and 5, or only tergite 5, with a pair of small dark lateral spots. Sternites yellow. In posterior view, tergites thinly whitish to greyish dusted except on hind-margins. Macrochaetae well-developed and erect: tergite 3 with some lateral marginals, tergite 4 with some lateral discals and a marginal row, tergite 5 with discal and marginal rows. Sternite I dark to pale setulose. Genitalia: Text-figs. 99, I02, 105. Measurements: Length of body, $6 \cdot 0-7 \cdot 0 \mathrm{~mm}$. Length of wing, $5 \cdot 5-6 \cdot 5 \mathrm{~mm}$.

ㅇ. Differs from the male as follows. Head: Eyes broadly separated; frons at middle less than an eye-width, broadening gradually to lunula. Upper inner eye-facets not enlarged. Ocellar setae strong, slightly longer than anterior prst $d c$ seta, directed forwards and slightly outwards. $V t i$ strong, directed upwards and slightly inwards, slightly longer than the outcurved vte; vte twice as long as an adjacent post-ocular setula, longer than the outcurved pvt. Parafrontal pruinosity becoming thin and grey to brown in upper half of frons. Interfrontalia black in ground-colour; viewed from below, grey pruinose with the frontal triangle weakly brownish tinged; frontal triangle otherwise visible as a subshining black streak extending three-quarters distance from anterior ocellus to lunula. Parafrontalia slender, broadening gradually towards lunula; at middle a parafrontale equal to two to two and a half times diameter of anterior ocellus and quarter width of interfrontalia, at lunula broader than width of 3 rd antennal segment. Interfrontalia broadest at middle of frons, at lunula a little broader than a parafrontale (as in fusconota, Text-fig. 26), bare. I pair of strong inclinate ori at lunula, with 3-4 weaker pairs above them, all on lower three-fifths of frons; 2 pairs of strong reclinate ors, the upper pair stronger and placed closer to lower pair than to $v t i$; parafrontalia otherwise with short proclinate setulae from ors to lunula. 3rd antennal segment rather infuscated beyond arista. Parafacialia broader, opposite insertion of arista equal to almost twice diameter of anterior ocellus. Thorax: Viewed from above and behind, mesonotum undusted, rarely with a small weak median spot of white dust at neck. Scutellum undusted. Prsc acr placed on or in front of the transverse level of prsc $d c$. Inner $h$ and anterior $p h$ weaker. Anterior $i a$ sometimes absent. Propleural and prostigmatal ground-setulae dark, or dark and pale, or pale. Notopleuron bare around ist seta, rarely with some dark setulae. Hypopleuron with dark hairs below spiracle. Squamopleuron 
with dark setulae. Scutellum with I-5 setulae just below the level of the strong setae. Legs: Hind tibia sometimes darkened. Hind femur with I strong and I-3 weak preapical av setae. Wings: Usually rather conspicuously smoky. Stem-vein bare above. Abdomen: Ground-colour yellow, with variable dark markings: tergites $\mathrm{I}+2$ and 3 yellow; tergite 4 yellow, or with a weak to strong dark median crescent; tergite 5 yellow to dark with a pale mid-line or with large spots not quite meeting medially. Viewed from behind, virtually undusted. Macrochaetae reduced: tergite 5 with erect discal and marginal rows, the marginal row often confined to a few laterals, otherwise tergites 3 and 4 with discal and marginal setae short and confined to lateral parts of tergites. Measurements: Length of body, 5.5-6.5 mm. Length of wing, 5.0-6.0 mm.

Holotype ơ. QueEnsLand: Palm Island, 20.xii.I930-6.i.I93I (I. M. Mackerras), CSIRO.

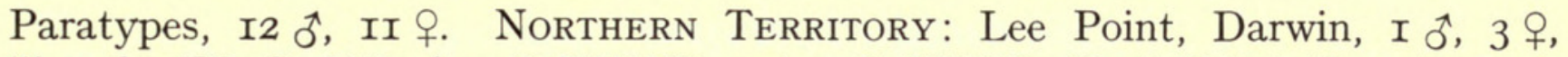
7.iii.I967 (M. S. Upton), I ㅇ BMNH, I ô, 2 + CSIRO; East Point, Darwin, I ô, I2.vi.I964 (K. R. Norris), CSIRO; Howard Springs, 4 + , I2.vi.Ig64 (K. R. Norris), 2 BMNH, 2 CSIRO; Arnhem Land, Maningrida, 5 m., Malaise-trap, I ô, I , , I8 and I9.iii. I96r (J. L. \& M. Gressitt), Bishop.

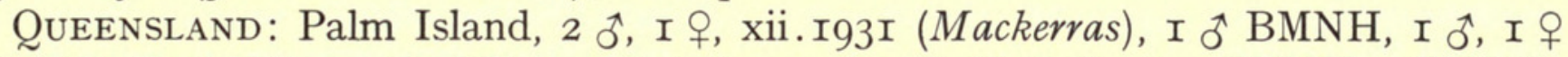
CSIRO; Earl Hill, north of Cairns, 6 ô, 8.v. I967 (D. H. Colless), 2 BMNH, 4 CSIRO; Mossman, I +, 25 .iii. I967 (M. S. Upton), CSIRO; Mt. Bartle Frere, East base, $80 \mathrm{ft}$., I 9 , 25.iv. I955 (K.R. Norris), CSIRO; Cairns, coll ex cage, I ô (J.F. Illingworth), USNM [det. by Malloch as apicalis].

Distribution and biology: Australia: Northern Territory and Queensland. An uncommon species.

This species occurs primarily in lowland rain forest, even in residual patches, and has also been found in scrub near the sea-shore and in riverine rain forest in savannah woodland. It has been collected in Malaise-traps.

Life-history and immature stages unknown.

Variation: The colour of the prosternal setulae may be pale or dark, dark in $40 \%$ of the specimens examined, and varies within populations. The hypopleural hairs below the spiracle are usually yellow in the male and dark in the female. Hind tibia and hind metatarsus are usually yellow, as on the other legs, but are sometimes infuscated or even black. The male from East Point has the few $p v$ setulae on hind femur rather stronger and more numerous than usual, and the male from Arnhem Land has 2 av setae on hind tibia. One of the males from Earl Hill has the vallar ridge bare, hypopleuron bare below spiracle, stem-vein bare above, and mid femur with $a$ and ad preapical setae.

The dark markings on the abdomen vary considerably and it is difficult to establish a consistent pattern. In the male, tergites 4 and 5 , or tergite 5 alone, have a pair of dark lateral spots, but in one male the hind-margin of tergite 3 and all of tergites 4 and 5 are dark. In the female, some specimens have the abdomen entirely immaculate; more usually, tergite 4 and 5 are extensively darkened in the form of spots, triangles or bands, and in some specimens even tergite 3 is extensively darkened and tergite 4 and 5 entirely dark.

Affinities: D. soror is most closely related to the Australian arrogans, the New Guinea rufescens and the Oriental apicalis. Its affinities with these species are shown 
in the key (p. 209) and in the notes under apicalis and rufescens. The male 5 th sternite is very characteristic and is most similar to that of vicaria (Walker) and related species: the median cleft is flanked by rather short stout setulae (Text-fig. 99).

Discussion: Malloch (I925:326) recorded apicalis (Stein) from Australia on the basis of one male from Cairns, Queensland. This male is in the USNM. I have studied it and find that it belongs to my species soror and not to apicalis.

\section{CATALOGUE OF AUSTRALIAN DICHAETOMYIINI}

Names in synonymy indented. Misidentifications not included.

\section{Tribe DICHAETOMYIINI Emden, I95I \\ DICHAETOMYIA Malloch, I92I}

Type-species: Dichaetomyia polita Malloch, I92I, nec Stein, I900 (= emdeni n. n.), by original designation and monotypy.

quadrata-group

iohannis Pont, I967

armata-group

longiseta Pont, 1967

norrisi Pont, 1967

significans (Walker, I859)

helomyzina (Stein, I900) syn. $\mathrm{n}$.

spinipes (Stein, I9I8) syn. $\mathrm{n}$.

impar-group

parimpar sp. n.

breviseta sp. $\mathrm{n}$.

vicaria-group

terraereginae Malloch, 1925

rufaeformis sp. $\mathrm{n}$.

megophthalma Malloch, I925

australis sp. $\mathrm{n}$.

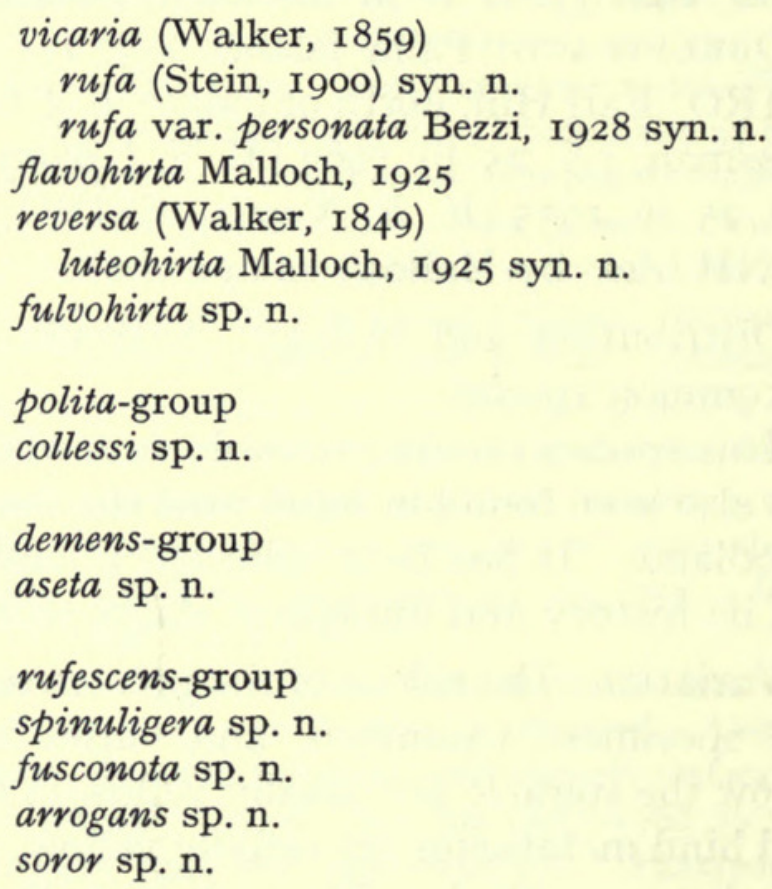

\section{REFERENCES}

BezzI, M. I928. Diptera Brachycera and Athericera of the Fiji Islands, based on material in the British Museum (Natural History). viii $+220 \mathrm{pp}$. British Museum (Natural History), London.

Curran, C. H. 1928. Diptera of the American Museum Congo Expedition. Part II. Bull. Am. Mus. nat. Hist. 67 : 327-399.

Emden, F. I. van. I942. Keys to the Muscidae of the Ethiopian Region: Dichaetomyia-group. Ann. Mag. nat. Hist. (I I) $9: 673-701$ and 72 I-736.

- I95I. Muscidae, C.-Scatophaginae, Anthomyiinae, Lispinae, Fanniinae and Phaoniinae. Ruwenzori Exped. 1934-35 2 (6) : 325-710. British Museum (Natural History), London.

- 1965. Diptera 7, Muscidae, Part I. Fauna of India and the adjacent countries. xiv + 647 pp. Government of India, Delhi.

Enderlein, G. 1927. Dipterologische Studien. XVIII. Konowia $6: 50-56$.

Given, B. B. I968. List of Insects collected on Niue Island during February and March, I959. N. Z. Ent. $4: 40-42$. 
Hennig, W. I952. Dipteren von den Kleinen Sunda-Inseln aus der Ausbeute der SundaExpedition RENSCH. IV. Fam. Muscidae. Beitr. Ent. 2 : 55-93.

I955-64. 63b, Muscidae. Fliegen palaearkt. Reg. I,I Io pp. E. Schweizerbart'sche Verlagsbuchhandlung, Stuttgart.

I965. Vorarbeiten zu einem phylogenetischen System der Muscidae (Diptera: Cyclorrhapha). Stuttg. Beitr. Naturk. Nr. I4I : roo pp.

Hori, K. \& Kurahashi, H. I967. Three Species of Japanese Dichaetomyia, with Description of Two New Species (Family Muscidae, Diptera). Sci. Rep. Kanazawa Univ. $12: 67-74$.

Lee, D. J., Crust, M. \& Sabrosky, C. W. I956. The Australasian Diptera of J. R. Malloch. Proc. Linn. Soc. N.S.W. 80 [1955] : 289-342.

Malloch, J. R. I921a. Exotic Muscaridae (Diptera).-I. Ann. Mag. nat. Hist. (9) 7 : I6II 73 .

I92 Ib. Exotic Muscaridae (Diptera).-II. Ann. Mag. nat. Hist. (9) $7: 420-43$ I.

I924. Notes on Australian Diptera. No. II. Proc. Linn. Soc. N.S.W. 49 : 138-146.

1925. Notes on Australian Diptera with descriptions of thirteen new species. Aust. Zool. $3: 322-338$.

— I928a. Exotic Muscaridae (Diptera).-XXI. Ann. Mag. nat. Hist. (1о) 1 : 465-494.

1928b. Fauna sumatrensis (Beitrag Nr. 56). Family Muscidae (Dipt.). Ent. Mitt. 17 : 290-303 and 310-336.

1929a. Fauna Buruana. Diptera, Fam. Muscidae. Treubia $7: 390-408$.

I929b. Muscidae. Insects Samoa 6 (3) : I5I-175. British Museum (Natural History), London.

- 1930. Exotic Muscaridae (Diptera).-XXIX. Ann. Mag. nat. Hist. (1о) 5 : 465-484.

Meijere, J. C. H. DE. I906. Résultats de l'Expédition Scientifique Néerlandaise à la NouvelleGuinée en 1903 sous les auspices de Arthur Wichmann, chef de l'expédition. Diptera. Nova Guinea 5 (Zoologie) : 67-99.

Pont, A. C. I966a. Notes on the Muscidae of New Guinea (Diptera). I. The types of Francis Walker. Ann. Mag. nat. Hist. (13) 9 : 87-99.

I966b. Notes on the Muscidae of New Guinea (Diptera). II. Species described by Stein in the Annali Mus. Civ. St. Nat. "G. Doria ", Genova (1900). Annali Mus. civ. Stor. nat. Giacomo Doria 76 : 93-102.

I967a. Studies on Australian Muscidae (Diptera). I. Some species of Dichaetomyia Malloch. Aust. J. Zool. 15 : 6r9-640.

I967b. Noona Dan Papers No. 43. Some Muscidae (Diptera) from the Philippine Islands and the Bismarck Archipelago. I. The Genus Myiophaea Enderlein. Ent. Meddr 35 : 105-I 24 .

I968. Notes on the Muscidae of New Guinea (Diptera). IV. Species described by Stein from i9ro to i920. Ent. Ber., Amst. 28: I66-I74.

In press. Notes on the Muscidae of New Guinea (Diptera). III. Species described by Stein in I900, Természetr. Füz., Volume 23. Dt. ent. $Z$.

SÉGuy, E. I937. Muscidae. Genera Insect. 205, 604 pp. Desmet-Verteneuil, Brussels.

SNyder, F. M. I965. Muscidae. Insects Micronesia 13 (6) : I9I-327. Bishop Museum, Honolulu.

Stein, P. I900a. Einige dem Genueser Museum gehörige aus Neu-Guinea und Umgegend stammende Anthomyiden. Annali Mus. civ. Stor. nat. Giacomo Doria 40 : 374-395. I9oob. Anthomyiden aus Neu-Guinea, gesammelt von Herrn L. Biró. Természetr. Füz. 23 : I 29-I59.

r9or. Die Walker'schen aussereuropäischen Anthomyiden in der Sammlung des British Museum zu London (Dipt.). Z. syst. Hymenopt. Dipterol. 1 : I85-22 I.

1904. Einige neue javanische Anthomyiden. Tijdschr. Ent. 47 : 99-II3.

1909. Neue javanische Anthomyiden. Tijdschr. Ent. 52:205-27I.

1918. Zur weitern Kenntnis aussereuropäischer Anthomyiden. Annls hist.-nat. Mus. natn. hung. 16 : I47-244. 
Stein, P. I9I9a. Die Anthomyidengattungen der Welt, analytisch bearbeitet, nebst einem kritisch-systematischen Verzeichnis aller aussereuropäischer Arten. Arch. Naturgesch. 83 A I [I9I7] : 85-I78.

r919b. Zur Anthomyidenfauna Neu-Guineas. Nova Guinea 13 (Zoologie) : 199-2Ir.

r920. Anthomyiden aus Java, Sumatra, Waigeoe und Ceram. Tijdschr. Ent. 62 [I9I9], Suppl. : 47-86.

Steyskal, G. C. I965. Notes on types of some species described in Sciomyza and Tetanocera by Loew, Walker and Van der Wulp (Diptera: Sciomyzidae, Muscidae, Neriidae, Pyrgotidae). Studia ent. $8: 445-448$.

WALKer, F. I849. List of the specimens of Dipterous Insects in the collection of the British Museum 4 : 689-II72. British Museum, London.

I859. Catalogue of the Dipterous Insects collected in the Aru Islands by Mr. A. R. Wallace, with Descriptions of New Species. J. Proc. Linn. Soc. 3 : 77-131.

\section{INDEX}

\section{Aethiopomyia, i99}

\section{Agdestis, 199}

Alluaudinella, 199

apicalis (Stein), 263, 269

apicalis (Stein) of authors, 269, 273

armata (Stein) of authors, 2I3, 2I 4, 215, 217

arrogans sp. n., 209, 269, 270

aseta sp. n., 207, 260

atratula Malloch, 257

Auria, I99

australis sp. n., 203, 230, 239

bifasciata (Stein), 260

breviseta sp. n., 202, 21 8,224

canivitta (Walker), 2 I9

carolina Synder, 260, 262

caucasica Pont, 209, 2 I I

collessi sp. n., 207, 257

demens (Stein), 260

Dichaetomyia, 199

emdeni n. n., 199

flavohirta Malloch, 205, 206, 248, 254

fulvitarsis Malloch, 257

fulvohirta sp. n., 206, 255

fumicosta fumicosta Malloch, 230, 239, 24I

fumicosta savaii Malloch, 230, 239, 24I

fusciventris Emden, 257

fusconota sp. n., 207, 266

Gordonia, I99

GraUeria, I99

HARDYIA, I99

helomyzina (Stein), 2I 4,2 I 5 impar (Stein), 218, 2 I9

impar (Stein) of authors, 219, 224

incerta (Stein), 263, 268

indica (Walker), 257

johannis Pont, 200, 209, 210

latitarsis (Stein), 263, 266

leucoceros (Walker), 26o

lombokensis Hennig, 263

longiseta Pont, 201, 2I I, 2 I 2

Lophomala, I99

luteohirta Malloch, 25I

MACROXANTHOMYia, I99

malayana malayana Malloch, 2 I I

malayana tamil Emden, 2 I I

mariana Snyder, 230, 239, 24I

megophthalma Malloch, 203, 230, 238

Myiophaea, I99

Neaveia, I99

nigrita Malloch, 257

nigriventris Malloch, 257

nigrolineata (Stein), 257

nigroscuta Bohart and Gressitt, 263, 268

norrisi Pont, 20I, 2II, 2 I3

nubiana aureomarginata Emden, 209

nubiana nubiana (Bigot), 209, 223

OCHROMUSCA, I99

pallens (Stein), 219

PANAGA, 199

parimpar sp. n., 198, 201, 218, 219

parviseta sp. n., 21 8,228

peroe (Walker), 209, 2 I I 
phaeocnemis Emden, 209

polita Malloch, I99

polita (Stein), I99, 257

prolixa bioculata Emden, 230

prolixa pallidorsis Emden, 230

prolixa prolixa (Walker), 230

Pyrellina, I99

quadrata monticola Emden, 209

quadrata quadrata (Wiedemann), 209, 2 I I

reversa (Walker), 205, 206, 25 I, 255

RHyNCHOMYDAEA, I99

rigidiseta (Stein) of authors, 212, 2 I3

rota Snyder, 263

rufa (Stein), 242

rufa var. personata Bezzi, 242, 248 rufaeformis sp. n., 203, 234, 237

rufescens (Stein), 263, 269

sabroskyi Snyder, 263, 268

saperoi Bohart and Gressitt, 230, 239, 24I

scutellaris Malloch, 2 I I

setulifera (Stein) of authors, 210, 2 I I

significans (Walker), 20I, 2I I, 2I 4, 2 I 5

soror sp. n., 209, 269, 273

spinipes (Stein), 2I4, 2I 5

spinuligera sp. n., 207, 263

TAMILOMYIA, I99

terraereginae Malloch, 203, 23I, 237

trukensis Snyder, 230, 239, 24I

vicaria (Walker), 204, 242

yapensis Snyder, 230, 239

Adrian Charles Pont, B.A.(Oxon.) 

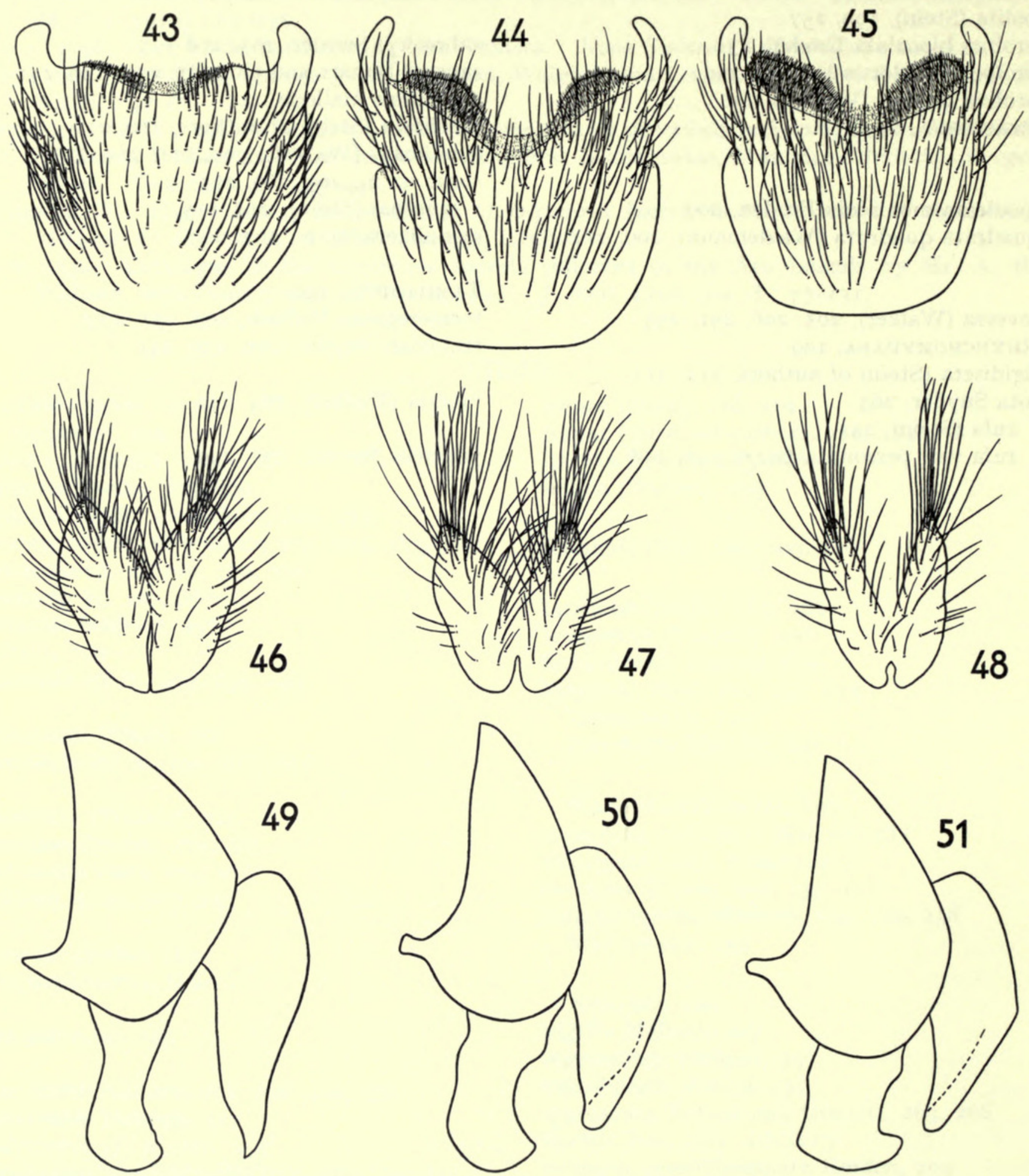

Figs. 43-5I. ot genitalia of Dichaetomyia. 43-45, 5th sternites, of: 43, D. longiseta Pont (Q, Gundamain, 23.viii. 1925); 44, D. significans (Walker) (PAPUA, Brown River, 7.v. I965); 45, D. norrisi Pont (Q, Moggill Farm, 27.i-I.ii.I96I). 46-48, Cercal plates, of: $46, D$. longiseta; $47, D$. significans; $48, D$. norrisi. 49-5I, hypopygia, lateral view (setae omitted), of: $49, D$. longiseta $; 50, D$. significans; 5I, D. norrisi. 

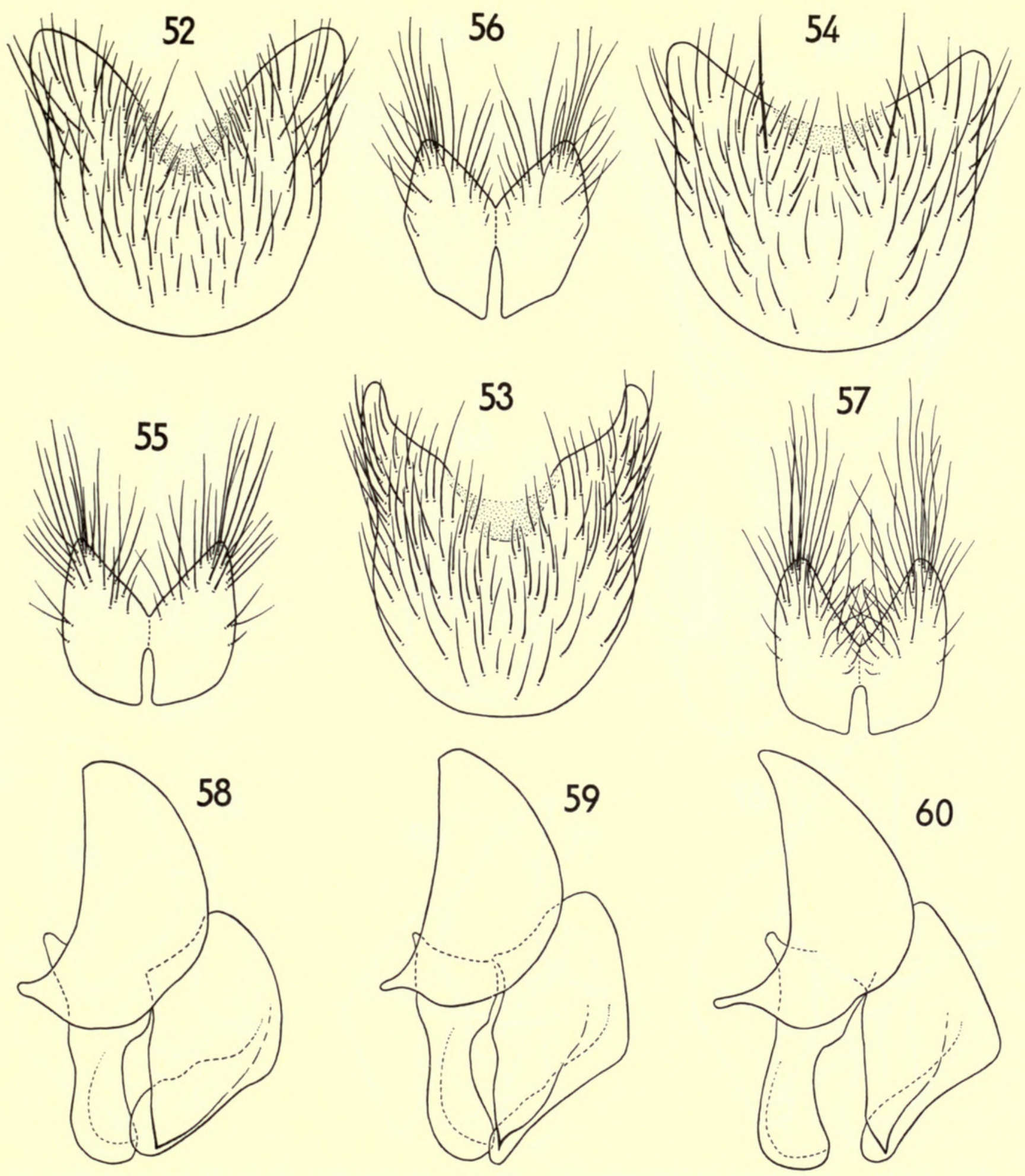

FIGs. 52-6o. $\sigma^{1}$ genitalia of Dichaetomyia. $\quad 5^{2-54}, 5^{\text {th }}$ sternites, of: $52, D$. parimpar sp. n. (N.S.W., Clyde Mt., 5.iv. I96o, paratype) ; 53, D. breviseta sp. n. (Q, Yeppoon, Io.v. I955, paratype); 54, D. parviseta sp. n. (Ugi, 6.v. I934, paratype). 55-57, cercal plates, of: 55, D. parimpar; $56, D$. breviseta; $57, D$. parviseta. 58-6o, hypopygia, lateral view (setae omitted), of: 58, D. parimpar; 59, D. breviseta; 6o, D. parviseta. 

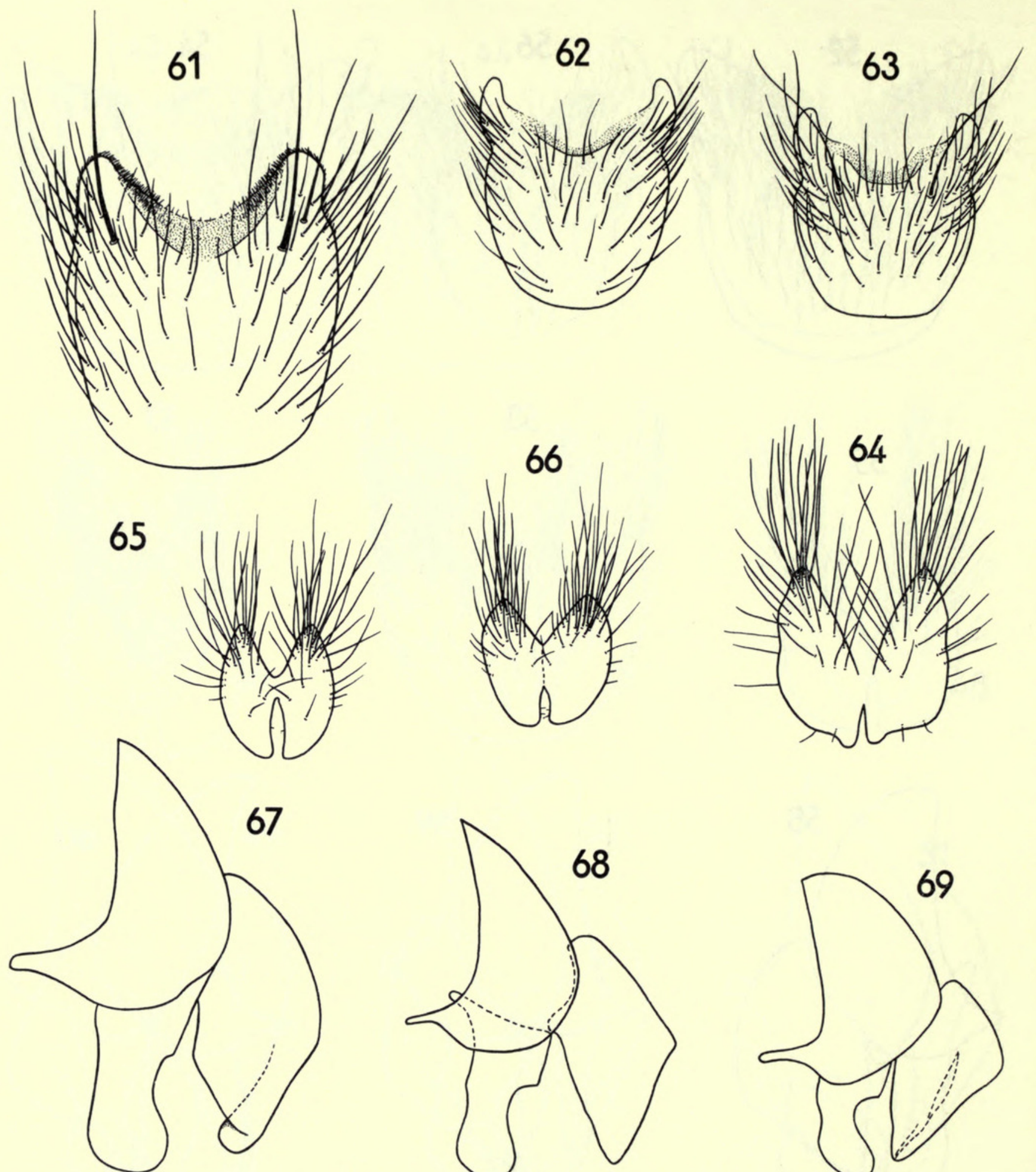

FIGs. 6I-69. ô genitalia of Dichaetomyia. 6I-63, 5th sternites, of: 6I, D. johannis Pont (Q, Cairns, ex corn); 62, D. terraereginae Malloch (Q, Bancroft, paratype); 63, D. rufaeformis sp. n. (Q, Byfield, Io.v.I955, paratype). 64-66, cercal plates, of: $64, D$. johannis; 65 , D. terraereginae; $66, D$. rufaeformis. 67-69, hypopygia, lateral view (setae omitted), of: 67 , D. johannis; 68, D. terraereginae; 69, D. rufaeformis. 

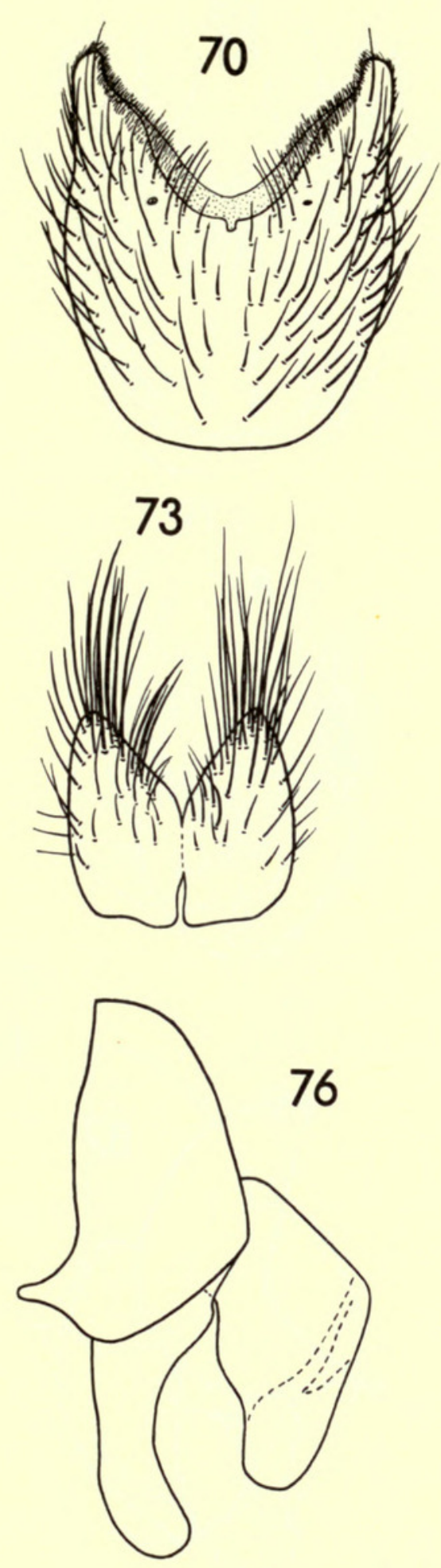
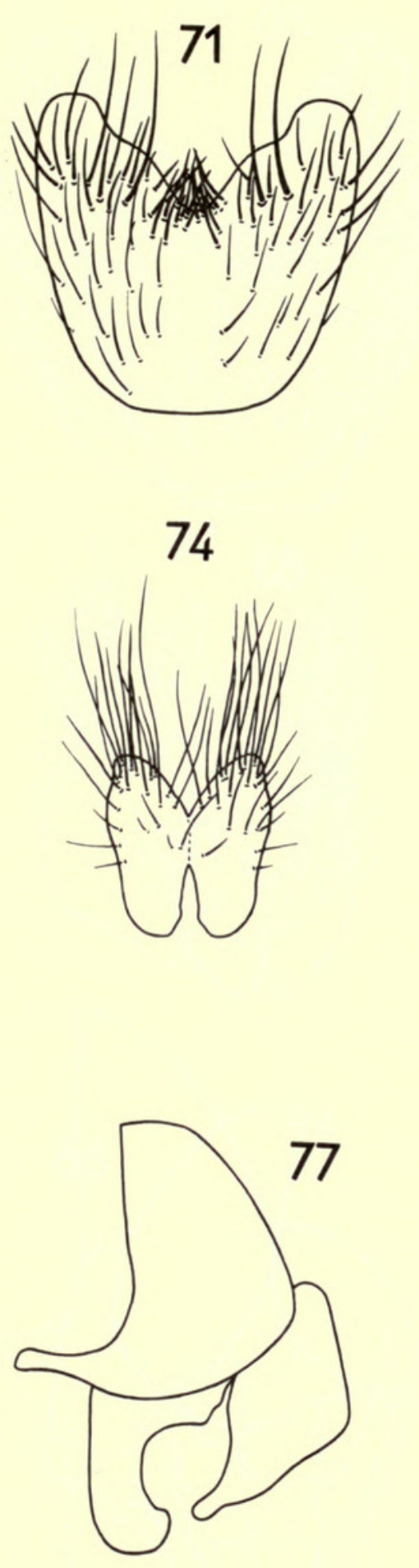

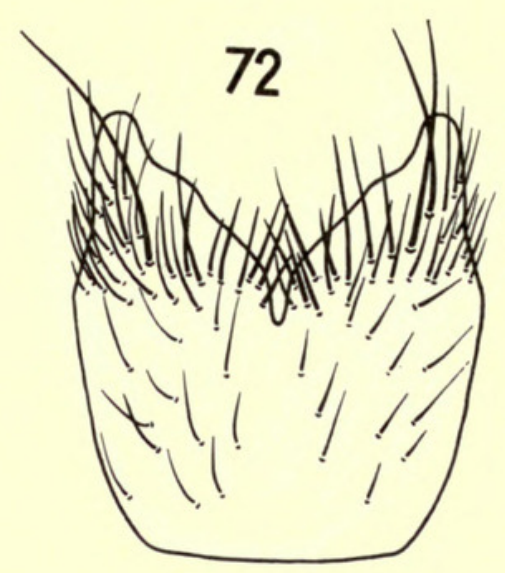

75
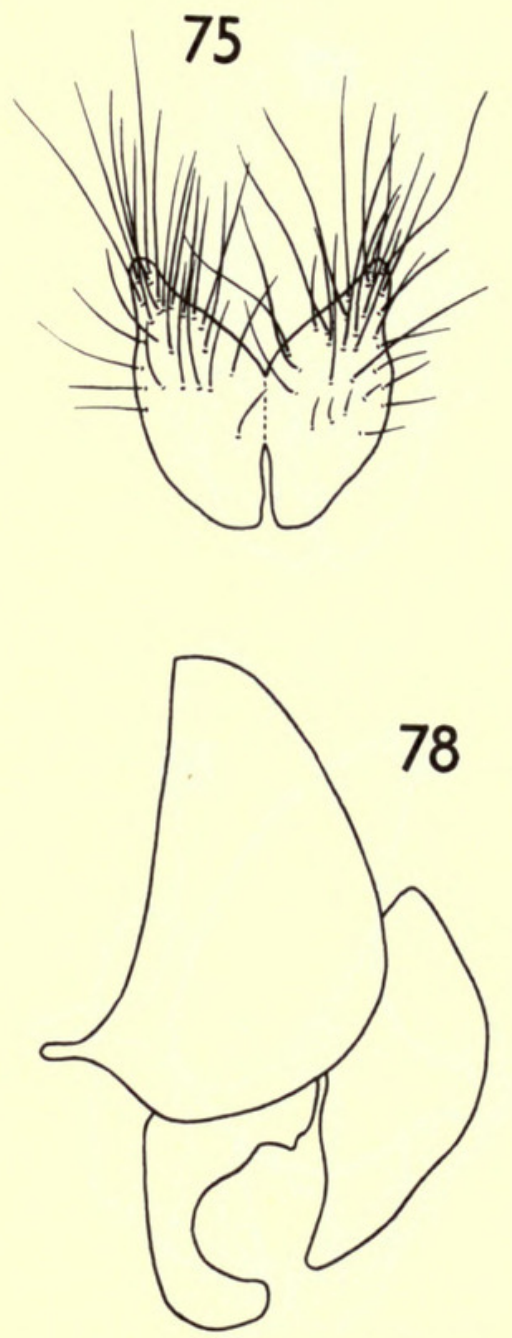

Figs. 70-78. $\sigma^{1}$ genitalia of Dichaetomyia. 70-72, 5th sternites, of: 70, D. collessi sp. n. (Q, Mossman Gorge, 23.iv. I967, paratype); 7I, D. australis sp. n. (Q, Bamaga, 28. iii. I964, paratype); 72, D. vicaria (Walker) (Q, I4 mls S.W. of Sarina, 8.v. I955). 73-75, cercal plates, of: $73, D$. collessi; $74, D$. australis; $75, D$. vicaria. $76-78$, hypopygia, lateral view (setae omitted), of: $76, D$. collessi; $77, D$. australis; $78, D$. vicaria. 

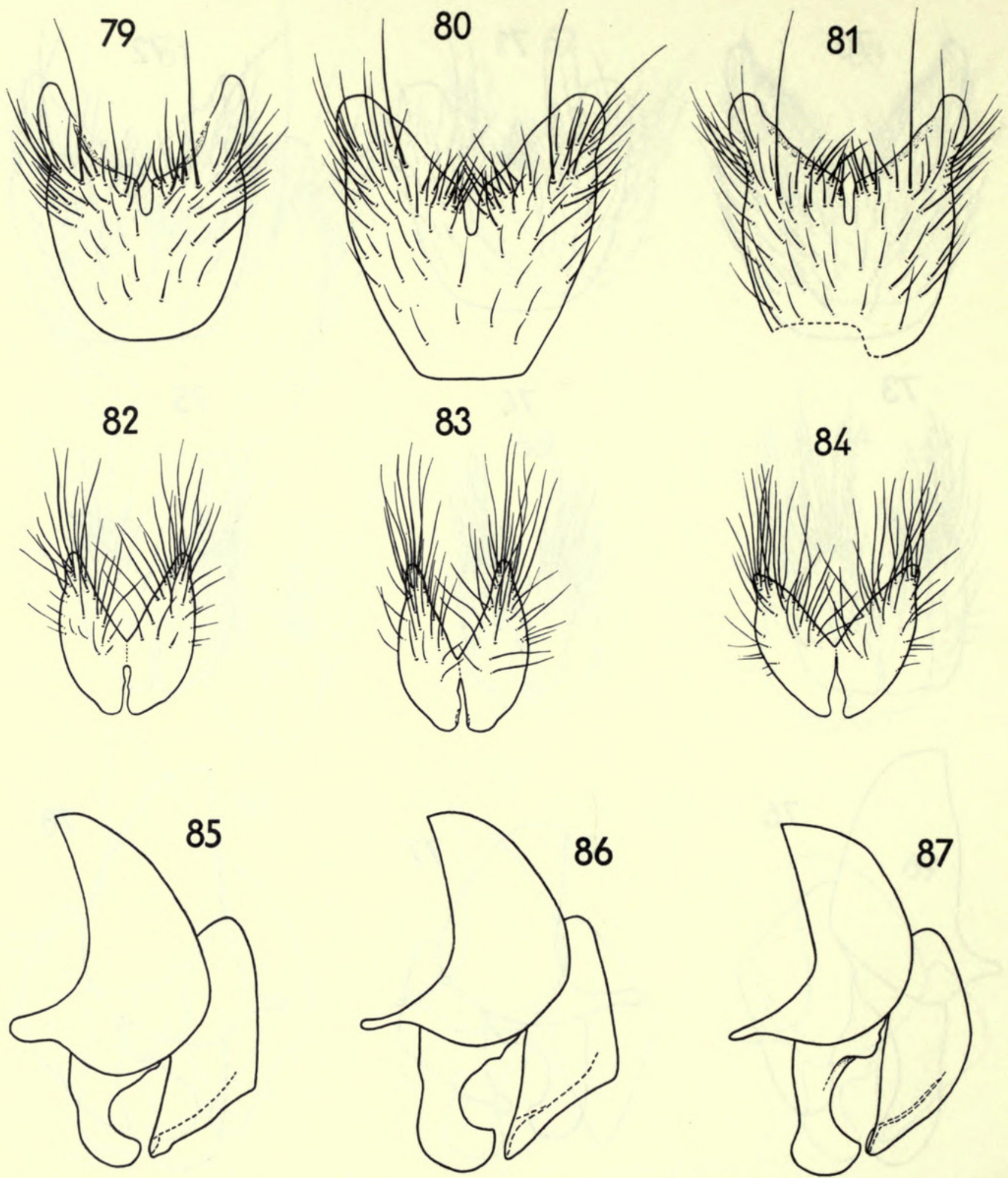

FIGS. 79-87. of genitalia of Dichaetomyia. 79-81, 5th sternites, of: 79, D. flavohirta Malloch (Q, Cairns, ex corn); 8o, D. reversa (Walker) (Torres Strait, Thursday Is.); 8I, D. fulvohirta sp. n. (holotype). 82-84, cercal plates, of: 82, D. flavohirta; $83, D$. reversa; $84, D$. fulvohirta. $85-87$, hypopygia, lateral view (setae omitted), of: $85, D$. flavohirta; 86, D. veversa; 87, D. fulvohirta. 

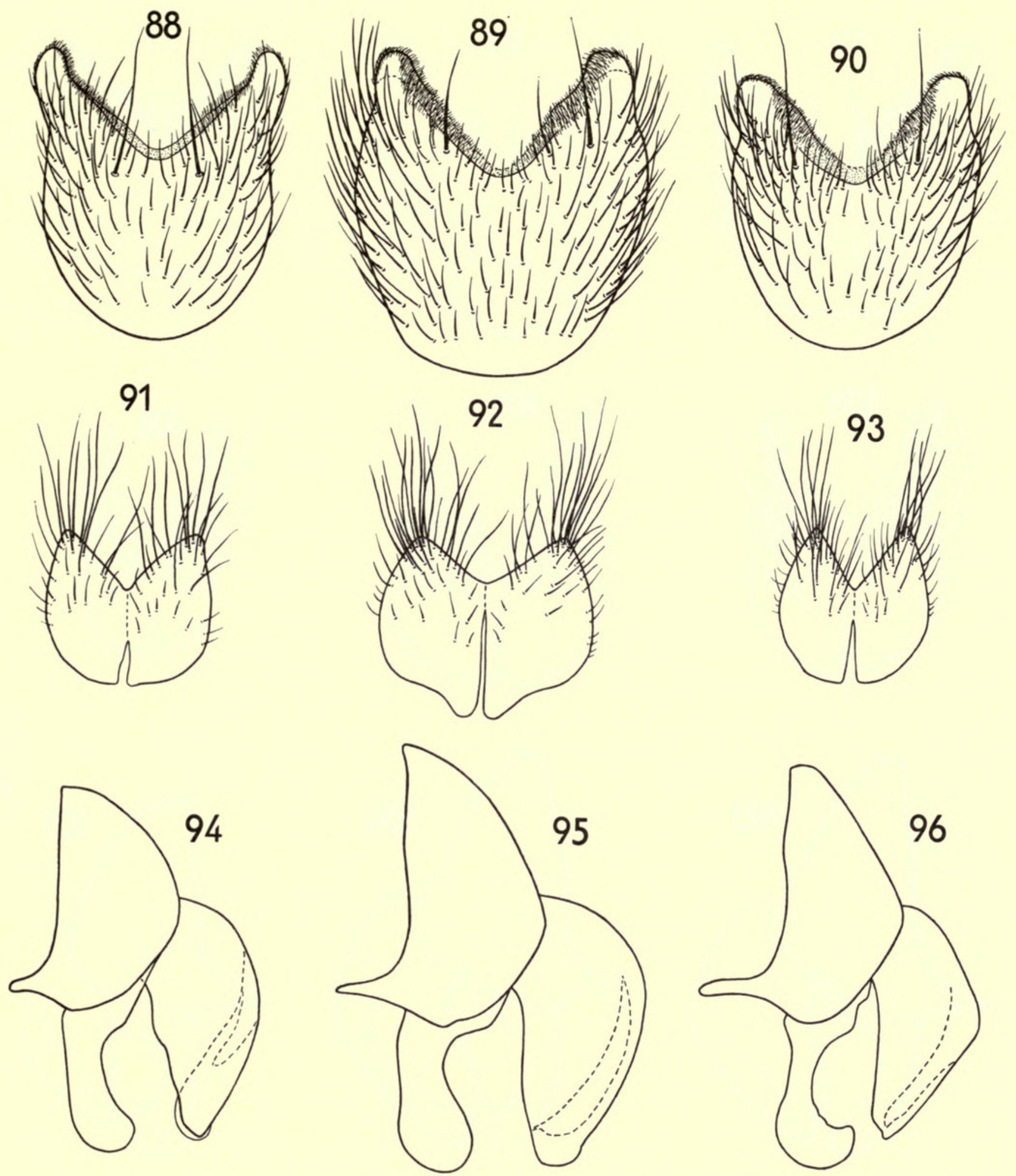

Figs. 88-96. đo genitalia of Dichaetomyia. 88-90, 5th sternites, of: 88, D. aseta sp. n. (Q, Kuranda Range State Forest, 20.iv. 1967, paratype); 89, D. spinuligera sp. n. (Q, Bamboo Ck, 25.iv.1967, paratype); 9o, D. fusconota sp.n. (Q, Kuranda, ix.r9Io, paratype). 9I-93, cercal plates, of: 9I, D. aseta; 92, D. spinuligera; 93, D. fusconota. 94-96, hypopygia, lateral view (setae omitted), of: 94, D. aseta (Q, Brunetti Coll., paratype); 95, D. spinuligera; 96, D. fusconota. 

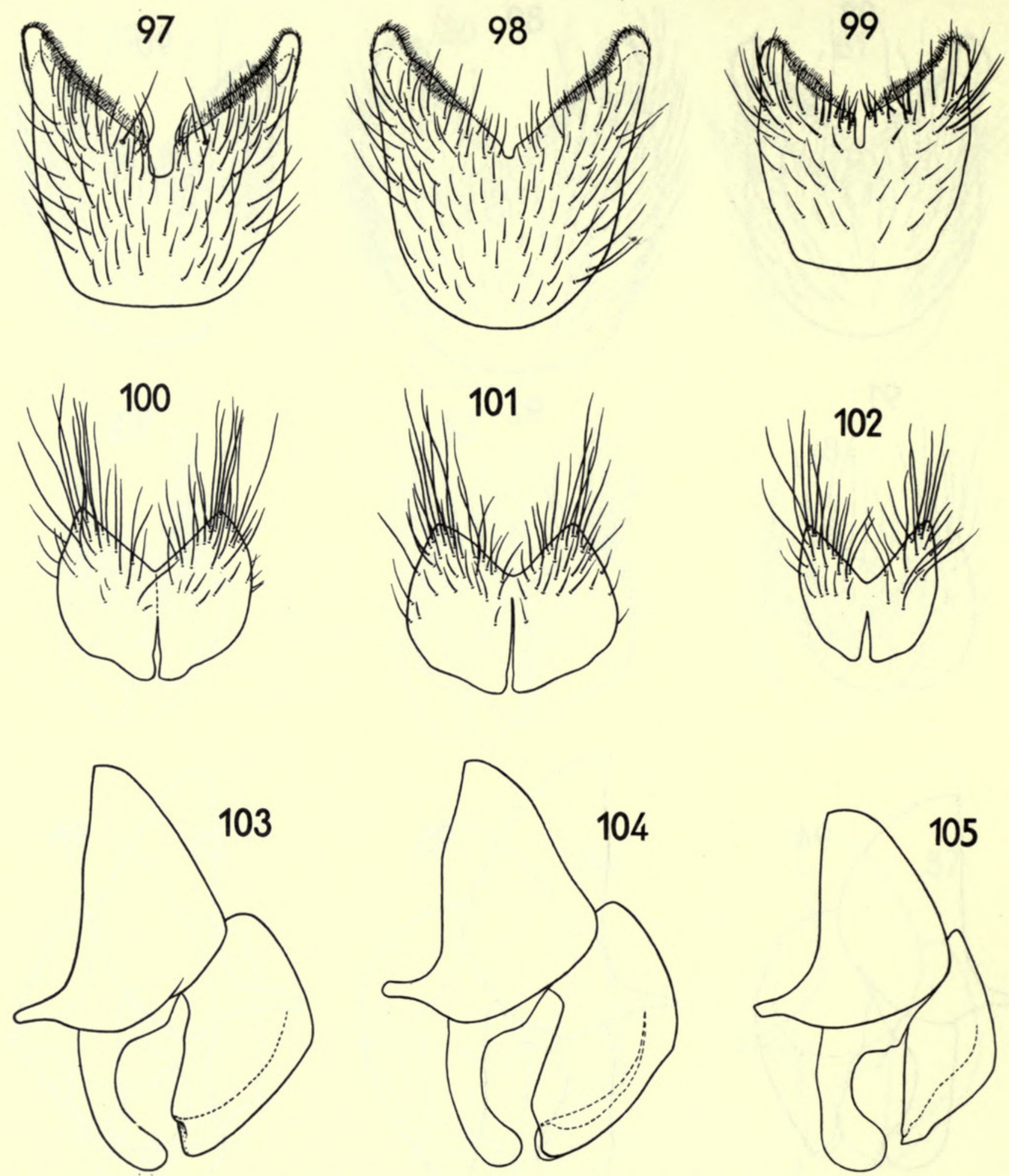

Figs. 97-105. of genitalia of Dichaetomyia. 97-99, 5th sternites, of: 97, D. apicalis

(Stein) (Assam, Ganbati, 21.x.1920); 98, D. arrogans sp.n. (Q, Upper Mulgrave R., 9.v.1967, paratype); 99, D. soror sp.n. (Q, Earl Hill, 8.v.1967, paratype). 10o-102, cercal plates, of: 100, D. apicalis; I01, D. arrogans; 102, D. soror. 103-105, hypopygia, lateral view (setae omitted), of: 103, D. apicalis 104, D. arrogans; 105, D. soror.

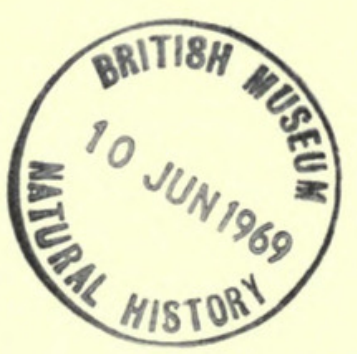




\section{$2 \mathrm{BHL}$ Biodiversity Heritage Library}

Pont, Adrian C. 1969. "Studies on Australian Muscidae (Diptera) II. A revision of the tribe Dichaetomyiini Emden." Bulletin of the British Museum (Natural History) Entomology 23, 191-286. https://doi.org/10.5962/bhl.part.15134.

View This Item Online: https://www.biodiversitylibrary.org/item/19545

DOI: https://doi.org/10.5962/bhl.part.15134

Permalink: https://www.biodiversitylibrary.org/partpdf/15134

\section{Holding Institution}

Natural History Museum Library, London

\section{Sponsored by}

Natural History Museum Library, London

\section{Copyright \& Reuse}

Copyright Status: In copyright. Digitized with the permission of the rights holder.

Rights Holder: The Trustees of the Natural History Museum, London

License: http://creativecommons.org/licenses/by-nc-sa/4.0/

Rights: http://biodiversitylibrary.org/permissions

This document was created from content at the Biodiversity Heritage Library, the world's largest open access digital library for biodiversity literature and archives. Visit BHL at https://www.biodiversitylibrary.org. 